\title{
A Medieval Catalan Horticultural Treatise, Memòria de les maneres de les Ilaurons: Introduction, Critical Edition, Translation, Notes and Glossary
}

\author{
Thomas M. Capuano \\ Truman State University \\ tcapuano@truman.edu \\ https://orcid.org/OOOO-OOO3-2864-9242 \\ Received 04/O2/2019; accepted oI/05/20I9 \\ DOI: https://doi.org/IO.7203/MCLM.6.I39I3
}

Abstract

The seven known witnesses to a hitherto unpublished medieval Catalan horticultural treatise are compared and analyzed. A critical edition is presented, with introduction, notes, English translation, and glossary. In an appendix, a synoptic edition provides transcriptions of all accessible witnesses to this text.

KEYWORDS

Medieval Catalan culture; manuscripts; philology; horticulture; Barcelona; Miquel Agustí; gardening

RESUM

Es comparen i analitzen els set testimonis coneguts d'un tractat d'horticultura medieval fins ara inèdit. S'hi presenta una edició crítica, amb introducció, notes, traducció a l’anglès i glossari. En apèndix, una edició sinòptica ofereix transcripció de tots els testimonis accessibles d'aquest text.

PARAULES CLAU

Cultura catalana medieval; manuscrits; filologia; horticultura; Barcelona; Miquel Agustí; horts

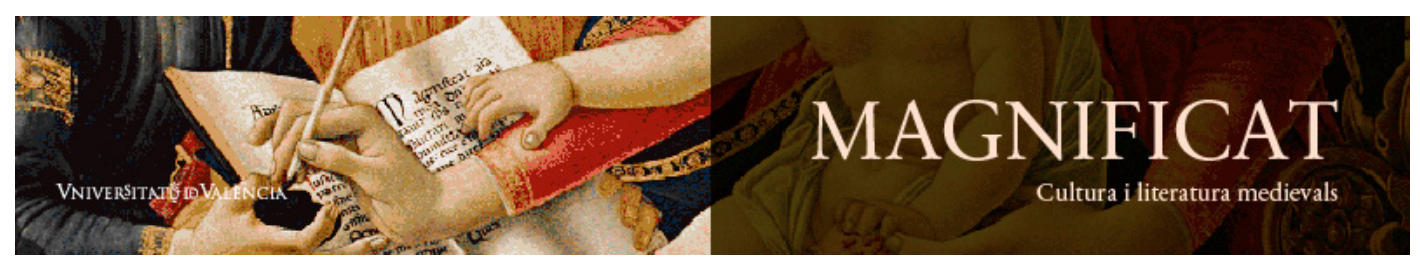

Magnificat Cultura i Literatura Medievals 6, 2019, I-97. http://ojs.uv.es/index.php/MCLM

ISSN $2386-8295$ 
Thomas M. Capuano. 20r8. 'A Medieval Catalan Horticultural Treatise, Memòria de les maneres de les llaurons: Introduction, Critical Edition, Translation, Notes and Glossary', Magnificat Cultura $i$ Literatura Medievals, 6: I-97

Este estudio ha sido realizado en el marco de los proyectos de investigación FFI2OII-29II7-Co2-OI (2OI2-2OI5) y FFI20I4-53050-C5-3-P (2015-20I8) del Ministerio de Economía y Competitividad (MINECO) del Gobierno español, cofinanciados con fondos FEDER de la Unión Europea.

\section{TABLE OF CONTENTS}

I Introduction - 3

${ }_{2}$ Critical Edition - 19

3 English Translation - 35

4 Works Cited - 42

5 Appendix I: Synoptic Edition of the Seven Witnesses of the Memòria de les maneres de les llaurons - 46

6 Appendix II: Comparison of a sample Memòria chapter with corresponding chapters in six representative medieval treatises on agriculture -87

${ }_{7}$ Index and glossary of terms related to horticulture $-9 \mathrm{I}$ 


\section{ə*⿻丷木}

\section{Introduction}

In 2015 in the pages of Manuscrits: Revista d'Història Moderna, I laid out arguments for the existence of an early Catalan treatise on horticulture, the Memòria de les maneres de les llaurons. This late medieval opuscule gives instructions for Barcelona and its environs on the cultivation of four types of garden crops: cabbages and other leafy vegetables; members of the onion family; root vegetables; and garden fruit such as melons, watermelons and calabash. The treatise has not come down to us whole but rather in fragments - some of which are much more complete than others - contained in six manuscript witnesses and adapted in one printed work, i.e., the first part of Miquel Agustí's well-known Llibre dels secrets de agricultura (I6I7), expanded and translated into Castilian in I626 as Libro de los secretos de agricultura. With my aforementioned article on the Memòria serving as backdrop, the present study endeavors to create a critical edition based on these fragments, and to serve as a guide for the identification of other witnesses to the Memòria that may come to light in the future.

The six manuscript fragments are summarized in the following list, presented in approximate chronological order. The initial abbreviations reference the city of the library where each manuscript is housed, followed by a tentative date of composition. Full codicological descriptions, when available, are referenced in footnotes.

$M=$ Late I $4^{\text {th }}$ century. Sixteen chapters, undifferentiated from the texts that precede and follow them, beginning on f. 2IIV3 and extending to f. 2I3VI of ms. IO2II of the Biblioteca Nacional de España, Madrid (Sciència.cat DB msi363; BETA manid 2288). ${ }^{.}$

$N=$ I5th century, second quarter. A fragment titled Memorial per lo exercici del conrear (f. 53 r) containing seventeen chapters that occupy ff. $53^{\mathrm{r}}-55^{\mathrm{V}}$ of ms. Brancacciana III A II of the Biblioteca Nazionale Vittorio Emanuele III of Naples in a codex dating to the $5_{5}$ th century. $^{2}$

$A={ }_{1} 5^{\text {th }}$ century, third quarter. Folios Ir-5v of a manuscript (BITECA manid 289I) in the private collection of the American hispanist Joseph Gwara, Annapolis, Maryland, USA, titled Memòria de les maneres de les llaurons (incipit: "En nom de deu sia / asso es mamorja deles maneres deles laurons..."). ${ }^{3}$

$V={ }^{4} 475^{-I} 5^{25} \cdot{ }^{4}$ Most of two folio sides (ff. 95r9-95V25) consisting of fourteen sections bearing the title "De la ortalisa quant se deu sembrar" of ms. 6437 of the Fons Serrano Morales of the Biblioteca Municipal de València (Sciència.cat DB ms475; BITECA manid ıo29).

I. Mario Schiff (I9O5: I52) dates this copy to the extreme end of the I4 ${ }^{\text {th }}$ c. (“Écriture de l'extréme fin du XIV" siécle”). For documentation of other datings and a full codicological analysis, see Sciència.cat DB msi363.

2. The Catalogo dei manoscritti della Biblioteca Brancacciana of the Biblioteca Nazionale di Napoli dates this ms. to the ${ }^{\text {th }}{ }^{\text {c }}$. Lluís Cifuentes i Comamala has dated the script of this fragment more specifically to the second quarter of the $\mathrm{I}^{\text {th }} \mathrm{c}$. (personal correspondence). For a description, see Benavent (2OO7: I4-I5, I5 $\left.5^{2-\mathrm{I}} 53,35^{\mathrm{I}}\right)$.

3. Described in Thomas M. Capuano (2006: 236-237). This is the only witness in our corpus for which no published edition yet exists. It is therefore not included in the present study, except for isolated fragments cited in this 2006 article. Lluís Cifuentes i Comamala has dated the script of this fragment to the third quarter of the $15{ }^{\text {th }}$ c. $\left(203^{-2 O I} 4\right.$ : 37).

4. Dated with full description in Giner Sánchez (I989: 54-5I7). 
$B=$ After I $495 .{ }^{5}$ The fifth part ("Libre quint o quinta part" IIgv7) of the Libre o regla of ms. 754 of the Biblioteca de Catalunya, Barcelona, beginning at f. II9v7 and extending to f. I22rig.

$P=$ End of the $5_{5}$ th - beginning of the I6th century. Twenty chapters, occupying folios 56 v8$62 \mathrm{r} 2$ and bearing the title "Del libre quint paladi" (f. $5_{56 \mathrm{v}}$ ), i.e., the fifth part of a treatise titled "De agricultura paladi” (f. 3Ov) of ms. espagnol 29I of the Bibliothèque Nationale de France, Paris. ${ }^{6}$

As shown in the aforementioned study (Capuano 20I5), all the textual witnesses share one remarkable feature in common: although each one shares space in their respective codices with other writings, the Memòria material is presented mostly together in each codex as one integral whole. The only exception to this pattern is the sole non-manuscript witness, Miquel Agustís Llibre dels secrets... (I6I7) ${ }^{7}$, which does not present the Memòria material together but rather interspersed with information from various sources. Nonetheless, the Memòria material is confined even in this witness to one section titled "Secrets dels horts y de les herbas y hortalisas de menjar" (Agustí I6I7: ff. 2Ir-3Or) and surprisingly, even though diverse sources frequently intervene, the Memòria borrowings follow the same basic order of presentation of vegetable crops as those presented in the manuscript witnesses.

However, the fragments also differ, and in very significant ways, as can be seen in complete detail in the synoptic edition offered in Appendix I below. Some of the most glaring divergences include the following: $M$ and $V$ (which follow each other very closely) radically abbreviate the text found in the other witnesses; both $P$ and $B$, unlike the others, present the Memoria material as the fifth part of a larger work; ${ }^{8} N$ contains barely one third of the chapters of the other manuscripts and yet is the only witness to include a chapter on fava beans; and $A$ is the only one to provide what may be the original title. Other occasional discrepancies concern the content itself, as, for example, when the witnesses recommend contrary lunar phases for certain operations, or when the prescribed planting, transplanting and harvest times for certain crops vary among witnesses. In an age when the agricultural reality of every community was physically all-encompassing and imposed itself on the collective consciousness, discrepancies such as the latter, when not reducible to simple copying errors, may reflect the climatological constraints known or assumed by each scribe for his region, or perhaps reflect an awareness of local horticultural practice.

In addition to the obvious ways our witnesses diverge from each other, lesser discrepancies beset them on virtually every level as well, including the phonetic, morphemic, lexical, and syntactic dimensions, expressive of the varying time periods and locations of each copyist. The copies span a period of over one hundred years, from the late fourteenth to the early sixteenth centuries, and represent diverse geographical areas. Although there is much uncertainty regarding the specific locations proposed for their places of composition, these range from Aragon for M(Sciència.cat DB msi363) to Sicily for $P$ (Sciència.cat $D B$ ms2o6) and from València and the Baix Maestrat for $V$ and $B$, (respectively, Sciència.cat $D B$ ms 376 ; Luna-Batlle 20II:Io) to Barcelona, the site of the original text, according to the title rubric of copy $A$. No evidence has yet emerged for the location of copy

5. See Capuano (20I4: 6) for an explanation of this dating.

6. For a codicological analysis see Sciència.cat DB ms2o6. Also described in Giner-Trenchs (1988:I49-I5I) and García Sánchez (1993-1994: 396).

7. Both this and the Castilian version, published during Agustís lifetime (Perpiñán, I626) have been consulted for this study, as well as later editions. For a bibliographic study of this work, see Pablo Núñez (2007-2008).

8. This larger work has seen three recent editions: Luna-Batlle (2OII), Martí Escayol (20I2: 25-29, 95-I25) and Capuano (2OI4). This larger work is attested in yet another witness containing six parts, of which the fifth is "de sembrar e plantar ortolises" as reported by Gabriel Llabrés (I895: I5I), but the whereabouts of this manuscript is currently unknown. 
$A$, nor for $N$. Add to these disparate elements the unique stylistic conventions each scribe seems to prefer, and the result is a horticultural treatise represented by an unusually wide range of variants. By comparing the versions of all seven of our witnesses yet another layer of variation appears: only in rare instances did the copyists feel compelled to copy verbatim from their antecedents, opting instead for a paraphrasing strategy that imprints with a unique stamp each manifestation of the Memòria. Indeed, each scribe appears to eschew the task of copying stricto sensu and opts instead to scan his source and then, taking his eyes away from its forms, render its ideas in his own local idiom. Appendix I shows many examples of this strategy along with the aforementioned discrepancies of time and place, as does this sample passage on cultivating winter cabbages. $\boldsymbol{V}^{\boldsymbol{n}} \boldsymbol{A}^{2} \boldsymbol{P} \boldsymbol{B} N$ Agustí I6r 7

\begin{tabular}{|c|c|c|c|c|c|}
\hline$\sqrt{9}$ & $\boldsymbol{A}^{\mathrm{IO}}$ & $P$ & $\boldsymbol{B}$ & $\boldsymbol{N}$ & Agustí I6I7 \\
\hline $\begin{array}{l}\text { [f. 95r] Lavor } \\
\text { de cols verts } \\
\text { de ivern se } \\
\text { sembren de } \\
\text { mijant juny a } \\
\text { mijant joliol } \\
\text { y deuense } \\
\text { tresplantar de } \\
\text { mijant agost } \\
\text { fins a mijant } \\
\text { dehembre ab } \\
\text { molts fems en } \\
\text { lluna vella y fan } \\
\text { a regar de.III. } \\
\text { en .III. dies fins } \\
\text { que sien preses } \\
\text { y apres segons } \\
\text { quen haura } \\
\text { mester }\end{array}$ & $\begin{array}{l}\text { [f. rr] Cols } \\
\text { qui son bones } \\
\text { djuern ço es que } \\
\text { hom les menja } \\
\text { en aquell temps } \\
\text { sembra hom } \\
\text { migant juny ho } \\
\text { entorn en luna } \\
\text { vella, e que agen } \\
\text { bon goret fet ab } \\
\text { eras \& ab molts } \\
\text { fems no massa } \\
\text { empero mas } \\
\text { per cominalesa. } \\
\text { E fan a regar } \\
\text { souen \& deu les } \\
\text { hom tresplentar } \\
\text { de migant agost } \\
\text { tro migant } \\
\text { setembre en } \\
\text { luna vella. \& } \\
\text { volen molts fems } \\
\text { al tresplentar } \\
\text { mes que al } \\
\text { sembrar. E deu } \\
\text { les hom regar } \\
\text { de tres en tres } \\
\text { dies tro que son } \\
\text { preses e [pulys }\end{array}$ & $\begin{array}{l}\text { [f. } 56 \text { v] de } \\
\text { cols de yuern } \\
\text { les quals fan a } \\
\text { sembrar migant } \\
\text { juny en luna } \\
\text { vella e que hi } \\
\text { aja e stia ben } \\
\text { barbeytada } \\
\text { cauada e femada } \\
\text { la terra pero ab } \\
\text { mesura lo femar } \\
\text { ni maça ni poch, } \\
\text { e fan a regar } \\
\text { soujnt he deuen } \\
\text { se tresplantar } \\
\text { de migant agost } \\
\text { fins migant } \\
\text { setembre en } \\
\text { luna que sia vella } \\
\text { e no volen masa } \\
\text { fem be que en lo } \\
\text { tresplantar ne } \\
\text { volen molt mes } \\
\text { que al sembrar } \\
\text { e regales dos } \\
\text { vegades la } \\
\text { sepmana entro } \\
\text { que sien ben } \\
\text { preses }\end{array}$ & $\begin{array}{l}\text { [f. IIgv] cols } \\
\text { que son bones } \\
\text { diuern ço es que } \\
\text { hom les menge } \\
\text { en aquell temps, } \\
\text { sembra les hom } \\
\text { mijant juny en } \\
\text { la luna vella e } \\
\text { quey hage bon } \\
\text { guaret feyt ab } \\
\text { vores e ab fems } \\
\text { covinentment, } \\
\text { no massa. E } \\
\text { fan a reguar } \\
\text { souin e deuense } \\
\text { tresplantar } \\
\text { de mijant agost a } \\
\text { mijant setembre } \\
\text { en la luna vella } \\
\text { e no volen } \\
\text { molts fems, e } \\
\text { al tresplantar } \\
\text { molt mes que } \\
\text { al sembrar e } \\
\text { reguense de IIII } \\
\text { en IIII tro son } \\
\text { ben preses puys } \\
\text { fan a reguar } \\
\text { dues vegades la }\end{array}$ & $\begin{array}{l}\text { [f. } 54 \text { r] les Cols } \\
\text { que hom vol que } \\
\text { sien bones per } \\
\text { ljuern sembrar } \\
\text { les mijant Juny } \\
\text { e en Juliol en } \\
\text { luna vella e que } \\
\text { hagen bon goret } \\
\text { fet ab eres fan a } \\
\text { transplantar } \\
\text { de mijant Agost } \\
\text { tro a mijant } \\
\text { setembre en } \\
\text { luna vella e no } \\
\text { spiguen ne son } \\
\text { tan longues e } \\
\text { volen molts fems } \\
\text { al transplantar } \\
\text { molt mes que } \\
\text { no al sembrar. } \\
\text { E regales hom } \\
\text { tantost com } \\
\text { son plantades e } \\
\text { despuys de tres } \\
\text { en quart dies. } \\
\text { dies. Despuys } \\
\text { que sien preses } \\
\text { fan a regar dues } \\
\text { voltes la setmana }\end{array}$ & $\begin{array}{l}\text { [f. } 23 r \text { r] Si voleu } \\
\text { menjar Cols en } \\
\text { lo hiuern, se } \\
\text { sembran en lo } \\
\text { Iuny en Lluna } \\
\text { vella, apres } \\
\text { que haura fet } \\
\text { lo ple, fent-los } \\
\text { bon goret, ab } \\
\text { molt fems, } \\
\text { ben podrits y } \\
\text { reposats, hanse } \\
\text { de regar souint, } \\
\text { trasplantantlas } \\
\text { à mig Agost, fins } \\
\text { à mig Setembre, } \\
\text { apres al cap } \\
\text { detres setmanas } \\
\text { collarles ab fems } \\
\text { y terra. } \\
\text { Lo tresplantar } \\
\text { tambe ha de ser } \\
\text { en Lluna vella, } \\
\text { que en la noua } \\
\text { posarian molt } \\
\text { molt argull, y } \\
\text { espigarian prest: } \\
\text { se han de regar } \\
\text { de [fol. } 23 v] \text { tres }\end{array}$ \\
\hline
\end{tabular}

9. In this table the two Castilian versions ( $M$ and Agustí I626) are omitted in order to allow for a comparison among monolingual (Catalan) renderings only. However, it will be noticed in the Appendix that $M$ follows $V$ very closely indeed, even favoring the subject noun "seeds' ("simjente" in $M$, "lauor" in $V$. See Appendix, rows 2-I5 to compare all the versions together of this passage.

Io. No published edition of $A$ exists as of this writing, although Joseph Gwara, owner of the codex, has promised a full edition and study. For this reason, all quotations from $A$ presented in this article derive solely from published excerpts in Capuano I994: 254-256 and Capuano 20I5, and from the facsimile of folio Ir as published in Capuano 2006: 240. 


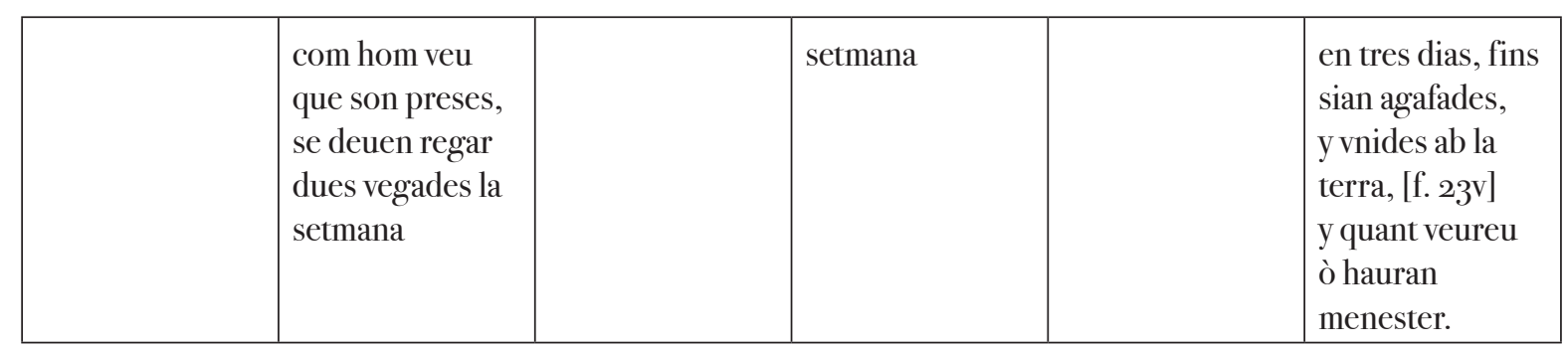

Leaving aside the obvious discrepancies of phonetic, morphemic and lexical quality, other discrepancies noticeable here include diverse syntactic structures, paraphrasing, and content that all corroborate our claim of a broad scribal license to diverge, adapt, and interpret a common source. We note, for example, that only three of these witnesses ( $A, B$, Agustí i627) clarify the term cols d'ivern as those that are consumed at this time; only two $(V, N)$ allow explicitly for a July sowing; only three $(A, B, N)$ qualify the soil preparation with the phrase fet ab eras/vores/eres (i.e., formed into beds); only three ( $A, P, B)$ caution that the manuring of the soil, while heavy, should not be excessive, expressing this concept through unique paraphrasing (respectively, "no massa empero mas per cominalesa"; "ab mesura lo femar ni maça ni poch"; "e ab fems covinentment, no massa"); that the watering regime prescribed for the transplants varies from every three days ( $V, A$, Agustí I6I7) to every four $(B)$ to every three or four $(N)$, to every other day $(P)$; and that the watering regime prescribed for the period after the transplants are established varies from as needed ( $V$, “segons que haura mester") to twice weekly $(A, B, N)$, while Agustí I6I7 appears to conflate both watering periods ("se han de regar de tres en tres dias, fins sian agafades, y unides ab la terra, y quant veureu ho hauran menester") and $P$ omits this second watering regime altogether.

Such wide ranging discrepancies have made difficult the selection of a base text for the present edition, but we have settled on $B$ for three reasons: it is the most unencumbered by obscure readings, it is the least incomplete of our witnesses, and it has received the careful attention of no less than three publications in the last decade. "We then devised editorial criteria that we believe represent the most conservative approach to a text as incompletely documented as the Memória: into this base text we have merged every complementary passage from each textual witness, provided that the merged passage does not violate or obscure the logic that informs the medieval horticultural science manifested in the Memòria. In the process of knitting together into the base text each discrepant passage we have made no attempt to reconcile the variations of form on the phonetic, morphosyntactic or lexical levels, but have rather concerned ourselves solely with content, striving to create a composite of the horticultural instructions contained across the corpus. In so doing we have created a linguistically artificial hybrid edition that weaves together the differing dialectal features of all the witnesses. Each insertion into the base text is accompanied by footnotes indicating its provenance. Because the printing of Agustís Llibre dels secrets de agricultura postdates most of our manuscript witnesses by well over a century, the incorporation of this version's early $\mathrm{I}{ }^{\text {th }}$ century prose style into an edition of a I5th century base text produces a reading excessively unnatural in places, but we believe that such inharmonious merging helps underscore the diverse provenance of each witness and serves as a constant reminder that our text is one for which no authoritative version has yet been found. In Appendix I each version is presented separately on its own terms, and for ease of comparison with all other available witnesses is presented synoptically.

There is evidence that as Miquel Agustí composed his work he held in his hands a copy of the Memòria, and that it was perhaps more comprehensive than any extant witness. We are indebted

II. Luna-Batlle (2OII), Martí Escayol (20I2: 25-29, 95-I25) and Capuano (2OI4). 
to María Antònia Martí Escayol (2008) for discovering the relationship between his Llibre dels secrets and $B$, our base text. As he begins his discussion of many horticultural crops in his first book ("Llibre Primer"), chapters 4-6, ${ }^{\text {I2 }}$ Agustí presents material extracted from the Memòria, as Martí Escayol has shown and as can be seen in our synoptic edition. Only after he has incorporated from the Memòria what he considers of importance for his purposes does he begin to elaborate from his own experience or cite other authors. It is especially noteworthy that, despite the broad sweep of his Llibre dels secrets, despite the complete editorial control he exerts over the wide array of texts he compiles, and despite the unfettered license he gives himself to incorporate, unannounced, observations from his own experience, Agustí almost slavishly incorporates phrases of the sort "com esta dalt dit de las altras" (23v; 'as mentioned above regarding the others'). Such phrases are the editorial deictics which the author of the Memòria uses to cross-reference topics treated elsewhere in his treatise. ${ }^{13}$ Other examples of this cross-referencing in our six manuscript witnesses include "axi com dich amunt", "axi com es dit deles altres", and "axicom dessus es dit" (see Appendix I, row $36)$.

Such aspects of the editorial process adopted by Agustí are often quite easy to pick out: when he draws from other authors, he usually cites them by name in the right or left margins of the i6 $\mathrm{I}$ ed. (though not in the I626 Castilian version). Although he is not consistent in this practice (as shown by Luna-Batlle 2OI5), he often takes pains to credit each source individually, at times crowding the margins with attributions to his many sources. The fact that he never mentions an author at the outset of each of the sections on horticultural crops - precisely when he is incorporating material from the Memòria - is both perplexing and fascinating. Why would a compiler who takes such pains to credit so many of his sources neglect to do so even once for the Memòria material he borrows? We believe that the complete absence of source citations in the opening instructions on each vegetable crop suggests that he was working from a hand written copy of the Memòria, and, because the text was most certainly anonymous, as it is in all our manuscript witnesses, Agustí felt it impossible to quote it with attribution. To visualize more effectively his process, we offer a short section below: in the first column we cite from our critical edition of the Memòria; in the second, Agustís text; and in the final column, the marginal notes including citation of sources as given in the I6I7 Catalan version. The text corresponds to rows $45^{-49}$ in Appendix I.

I2. Chapter 4 is "Secrets dels horts, y de les herbas y hortalisas de menjar" (f. 2Ir-25v), Chapter 5, "Secrets de las raels de las herbas de ortalisas" (f. $25 \mathrm{v}-28 \mathrm{v}$ ), and Chapter 6 "De secrets de les fruytes de les herbes" (f. $28 \mathrm{v}-3 \mathrm{Or}$ ).

I3. For examples of a similar adaptation of his sources, see the discussion of Agustí's "traducció servil” in LunaBatlle (2OI5: I2O). 


\begin{tabular}{|c|c|c|}
\hline $\begin{array}{l}\text { Critical Edition. } \\
\text { (See Appendix I rows 45-49). }\end{array}$ & Miquel Agustí, I6I7, f. $2_{4}$ r. & $\begin{array}{l}\text { Agustí's marginal citations } \\
(\text { (6 } 6 \text { I } 7, \text { f. 24r) }\end{array}$ \\
\hline [8] De spinachs & $\begin{array}{l}\text { Per fer espinachs que seran bons } \\
\text { en lo Iuern y Quaresma }\end{array}$ & \\
\hline $\begin{array}{l}\text { Spinachs menja hom en l'Avent de } \\
\text { Nadal. E haquests se volen sembrar } \\
\text { mijant agost ab la luna vella ab } \\
\text { molts fems, e fan a reguar a vagades } \\
\text { com hom coneix que o han ops. E } \\
\text { aquests spinachs són bons de ivern } \\
\text { [e] en Quaresma. }\end{array}$ & $\begin{array}{l}\text { Si voleu fer Espinachs que seran } \\
\text { bons en lo Iuern y Quaresma, los } \\
\text { sembrareu en lo mes de Agost en } \\
\text { Lluna vella, ab molt fems, y fan } \\
\text { a regar quant veureu ho auran } \\
\text { menester, y axi seran bons de Iuern } \\
\text { y Quaresma }\end{array}$ & Espinachs per lo Iuern y Quaresma \\
\hline [9] De spinachs encara & & \\
\hline $\begin{array}{l}\text { Encara, altres spinachs sembra hom } \\
\text { mijant setembre tro mijant octubre } \\
\text { en la luna vella. E regua'ls hom com } \\
\text { ho han mester, e sembra'ls hom } \\
\text { ab molts fems. E són bons de tota } \\
\text { Quaresma, si és alta o baxa. }\end{array}$ & $\begin{array}{l}\text { Altres Espinachs podreu fer per la } \\
\text { Quaresma, o sia alta, o baxa, si los } \\
\text { sembrau a mig mes de Setembra, } \\
\text { fins en mig de Octubre, en Lluna } \\
\text { vella, ab molt fems, y regarlos com } \\
\text { los altres, }\end{array}$ & \\
\hline [ı] De spinachs encara & & \\
\hline $\begin{array}{l}\text { Alguns ortolans diuen que la lavor } \\
\text { vella és millor que la de l'any mateix }\end{array}$ & y se fan millors de sement vella & \\
\hline & $\begin{array}{l}\text { Los espinachs son molt bons per } \\
\text { menjar en temps de Quaresma: } \\
\text { perque sen aparellan de moltes } \\
\text { maneras. Lo vs dels Espinachs es } \\
\text { bo per aquells qui estan impeditas } \\
\text { de la hale, y de la veu, y catarro } \\
\text { espes, principalment als matins, } \\
\text { prenent brou de Espinachs cuyts } \\
\text { ab Mantega fresca, o de Ametlles } \\
\text { dolces. }\end{array}$ & $\begin{array}{l}\text { Esteua. Per lo hale, y per la veu, y } \\
\text { tos espesa. }\end{array}$ \\
\hline
\end{tabular}

As can be seen on this table, Agustí follows the Memòria very closely in the first two paragraphs, abbreviates the Memòria in the third section ("y se fan millors de sement vella"), and then takes leave of this source to go off on his own in the fourth. There he seems to speak first from his own experience, declaring that spinach is especially good as a Lenten dish because it can be prepared in many ways, and then, citing "Esteua" (Charles Estienne, author of L'Agriculture et maison rustique, I564), ${ }^{\text {If }}$ he gives the multiple medicinal applications of spinach according to this author. In treating the cultivation of other vegetables, the citations and medicinal indications are often quite extensive, as in the case of lettuce (Agustí I6rz: f. 24r-25r) where the initial Memòria material (two paragraphs) is followed by an entire folio side of borrowings from Florentino, Mizaldo, Columela, Porta, Pallari,

I4. Luna-Batlle (2OI5: II6) provides a careful analysis of Agusti's sources, showing that the Prior made recourse to several editions of the Maison rustique, including the I57O edition co-authored with Jean Liébaut. 
Didimo and Esteua. From all this it should be clear that Agustís departures from the Memòria material are on the whole quite detectable simply by making note of the inception of his marginal attributions and comparing the material preceding them to our other witnesses.

For several horticultural crops, Agustís marginal citation of authors such as Esteua and Mizaldo begins right away at the outset of the section. This makes it easy to assume that the Memoria version he was using simply did not contain information on this crop, whence his immediate recourse to other sources. Examples include Swiss chard (bledas, f. 25r); parsley (iulivert, f. 25r); asparagus (esparechs, f. 25v); and cardoons (carts, f. 28v). Indeed, none of these vegetables is taken up in any of the other Memòria witnesses.

However, occasionally we find sections devoted to vegetables and other horticultural products that do not belong to any known Memòria tradition, and yet these sections likewise begin with paragraphs for which no sources are named in the margin. Examples include hemp and flax (canem and $l i i$ ), f. 25 v; artichokes (carxoferas), f. $28 \mathrm{v}$; and parsnip (xaravilles), f. $28 \mathrm{r} .{ }^{15}$ Luna-Batlle (2013: 68-69) and Martí Escayol (2008: 295) make it clear that Agustí makes frequent use of his own experiences in his treatise, so we are tempted to assume that he is doing precisely this in the opening passages for these four crops, since they do not coincide with any chapter in our other witnesses. However, Luna-Batlle (20I5: II4) shows that many uncited passages are also taken directly or indirectly from sources that Agustí - inexplicably - leaves unnamed. Thus, we must leave open the possibility that such uncited passages reflect this inconsistency. It is less likely, we believe, that they represent parts of the Memòria tradition that have been lost in the other witnesses.

Curiously, Agustí avoids the opportunity to acknowledge his use of any manuscript such as the hypothetical handwritten document that we posit as his source. Notably, he does not mention any Catalan source at all on the title page, where he makes his first pronouncement of his indebtedness to previous writers on agriculture. While he dutifully credits French, Latin, and Italian sources, he makes no mention whatsoever of Castilian or Catalan precursors: "Llibre dels secrets de agricvltvra casa rvstica pastoril. Recopilat de diversos autors antichs y moderns, de llenguas llatina, Italiana, y Francesa, en nostra vulgar llengua Catalana, per Fra Miquel Agusti Prior del Temple de la fidelissima Vila de Perpinya..." (Agustí I6r7, title page). Likewise, in his "Nomina dels autors dels quals se son tretes les materies del present llibre dels Secrets de agricultura, Casa Rustica y Pastoril, los quals estan notats al marge" given in the front material following the dedication to don Fra Onofre de Copons Batliu, there is no indication among the eighty-six names listed there that any anonymous sources were used for any part of his book. Furthermore, in his "Prolech del autor als aficionats en la professio, 0 art de la Agricultura..." which immediately follows the "Nomina", Agustí appears to claim not only that none of his sources were written in his native language, but also that no texts on agriculture even existed in Catalan:

...y encara que moltes persones, de mes subtil ingeni, y en mes auentatjada experiencia, han escrit diuerses coses, y secrets de la Agricultura, Casa Rustica y Pastoril, vns en llengua Llatina, altres en llengua Castellana, altres en llengua Italiana, altres en llengua Francesa, y altres en altres diuerses llengues, vehent que ningu se es ocupat à escriure en nostra llengua Cathalana, y pot esser que los que vuy exercitan la dita Agricultura, en nostra Cathalunya, no acertan en fer y posar les coses qual se deu, causantho per ventura, lo no entendre les llengues, perço en consideracio destas cosas, y per estar afectat á dita Professio, y tenir algunas experiencias della, me ha aparegut emplear algunes vigilies, y ratos de temps, particularment, estant desocupat dels negocis de ma Iglesia, en pendre

I5. The cultivation of parsnips may indeed belong to the Memòria tradition, since we find this crop taken up by two other witnesses. However, there is no correspondence among these three witnesses on this root vegetable (see Appendix, row I23.) 
treball de recopilar de diuersos y graues autors, antichs y moderns, y traduyr en nostra llengua Cathalana, modos y traças, per encaminar los que exercitan o voldran exercitar la Agricultura, y ofici pastoril, ajustanthi lo que per experiencia yo sabia, certificantlos, que mon intent, no es estat sino pera que los infinits secrets de la Agricultura, y ofici pastoril fosse comunicats, à tota nostra nacio Cathalana, y especialment als curiosos, y aficionats a ella... (Agustí r6r 7 : f. $5^{\mathrm{r}^{16}}$ )

The only way to understand Agustís apparent unfamiliarity with prior Catalan writing on agriculture and his easily disprovable claim that on this subject "ningu se es ocupat à escriure en nostra llengua Cathalana" ("no one has taken the trouble to write in our Catalan language') is to assume that for him and his peers, the only sources worthy of consideration were those that had been authenticated by the printing press. Until someone had "taken the trouble to write", i.e., to write about a certain source text - i.e., to consecrate it by editing it - a manuscript text could be considered, in a way, non existent. Only printed editions could convey the approbation of the intellectual community of that time, and the stamp of true modernity was borne only by those texts issuing forth from a printing press under the editorship of the "graues autors, antichs e moderns" that he references in this "Prolech".

If, in spite of his failure to cite the Memòria, we accept as obvious the debt that Agustí owes to the Memòria tradition, as Maria Antònia Martí Escayol has so amply demonstrated (2008, 20I2), a question still remains regarding the material in Agustí that is presented without any source attribution. How much of this material is taken directly from his own experience, how much may derive from lost Memòria sections, and how much comes from other unrelated anonymous texts that he might have had at hand in manuscript form, likewise orphaned from any of the "graues autors" that might have given them credibility? This question can be asked not only of textual material found in Agustí, but also of all the material, in any of our extant witnesses, that is not shared with any of the others. For example, only $N$ contains a chapter on fava beans; only $P$ contains a chapter on headforming cabbage ("cols de capdell"); and only $B$ contains instructions for planting calabash in hills (Appendix I, rows 5I, 38, IO8, respectively), as well as a chapter on nutsedge (row I24), and one on parsley (row I2 $5^{17}$ ). In addition, there are many other passages, even those within chapters shared across all the witnesses to the Memòria tradition, that are unique to only one witness. How much of this material would have been part of the Memòria as it was originally conceived?

The answer to this question will perhaps only become clear as more examples of the Memòria tradition come to light. In the meantime, in the present edition, we have endeavored to merge all compatible elements of the seven extant Memòria fragments with the goal of reconstructing a tentative version based on what we know so far about this text. By comparing the seven versions side by side and analyzing their style, omissions, abbreviations and elaborations, we have arrived at a version that attempts to incorporate all relevant cultivation instructions for each crop as they may have been presented by the original author. For editorial decisions that seemed unusually problematic, and in particular, for material we have opted to omit from our edition, we have given justification via footnotes, ${ }^{18}$ but even the omitted material can be evaluated by means of Appendix I, where we bring together in one place the full transcriptions of all seven witnesses.

I6. Emphasis added. This unnumbered fifth folio is the last of the preliminary material in Agustí r6ı. Folio 6r begins the work proper with the heading "F. Ir".

I7. Agustí's section on parsley is completely unrelated to the section in $B$.

I8. For example, two chapters in $P$, one containing instructions on how to grow a huge calabash and the other on growing mint, begin by appealing to the authority of King Solomon. No other Memória witness makes any mention of Solomon, and due to this marked divergence from the Memòria tradition we have excluded these chapters from our edition (but preserved them in the Appendix, row 5 , footnote). 
Much remains unknown about the Memòria de les maneres de les llaurons. It is still not clear why $V$ (and $M$, which mirrors it) and $N$ contain passages on grapes, fruit trees, grafting, cereal cultivation and wine correction, in contravention to the evidence identifying the Memoria as a text devoted to horticulture. ${ }^{19} \mathrm{~V}$, for example, immediately following the chapter on carrots and turnips (95 $\left.{ }^{\mathrm{v} 23^{-25}}\right)$, adds statements relating to arboriculture and viticulture, including recommendations on grafting, transplanting, and pruning (95 $\left.5^{\mathrm{v} 26-96 \mathrm{rr} 3}\right)$ before passing on to an unrelated agricultural menology, the Capitols singulars de les llauors que deuras sembrar en tot l'any cascun mes (96ri4). ${ }^{20}$ In fact, the horticultural trajectory that we have assumed throughout this study, and that is announced in the title of the Memória (in $V, A$, and $N$ ) is challenged from one notable historical record. Emilie Goujaud, in her registry of books in circulation in Perpignan in the late medieval period, includes "un livre traitant de la manière de jardiner, de tailler la vigne et de labourer [qui] appartenait au notaire Jean Candell de Perpignan"; this book is cited in the Cartulary d'Alart of I 454 with the entry "un libre del art de Ortalissa e de la podaho e de laurar continent en si dos sisterns de paper". ${ }^{2 \pi}$ Although the current whereabouts of this book is not known and no further details about it have come down to us, the joining together in its title of horticulture with pruning and working the soil ("labourer", "laurar") is a clear reminiscence of the similar chapters contained in $M, V, A$, and $N$ relating to viticulture, arboriculture, and wine correction. If we are to continue upholding our theory of a Memòria with an exclusively horticultural perspective, then the title cited in the Cartulary d'Alart suggests that already by the middle of the 15 th century compilers had merged the treatise on horticulture, or parts of it, with chapters from other writings that they considered important for their purposes. The clear prominence given to horticulture in the title of this lost volume, "un libre del art de Ortalissa...", together with the titles announcing the same in $V$, $A$, and $N$, reinforces this notion.

This argument has been put forth previously (Capuano 2OI5: 58-59). The heading given to the chapters on horticulture in $V$, "De la ortalisa quant se deu sembrar" (95r), and the title of the same in $A$, "Memòria de les maneres de les laurons, de plantar, \& de sembrar e de pensar que hom deu fer a tota ortalissa; la qual memòria es presa dels mjlors ortolans de Barchinona, specialment qui pensen de orts qui-s reguen" (Ir), provide the most compelling evidence that this text had a unique genesis. Now with the information contained in Goujaud's registry we can speculate that it arose before the middle of the I 5 th century. Notwithstanding this theory, as an acknowledgement of the uncertainty surrounding the Memòria tradition, and in the interest of providing as much information as possible concerning this text and the topics that were adjoined to it in the codices that preserve the Memòria, we have opted to provide in synoptic format in Appendix I an overview encompassing even the material not related to horticulture (rows I26- I54). It is our hope that as other researchers chance upon fragments of the Memòria tradition, our Appendix I will provide a convenient point of reference for this text and its place among the many Catalan agricultural writings that were in circulation during the $15^{\text {th }}$ century and earlier.

It will be noticed by the folio indications given in the synoptic edition that the non-horticultural material is never found integrated into the chapters on garden vegetables in any of the witnesses, although it does immediately follow in $M, V, A$ and $N$. The corresponding passages in $P$ and $B$ are not even contiguous with the chapters on vegetable cultivation. We offer these facts as further evidence that this non-horticultural material belongs to a source separate from the Memòria. Other indications that the add-on chapters are not part of the original Memòria include peculiarities of

I9. Capuano (20I5: 58-59).

20. For an edition of the Capitols singulars... see Capuano 1998.

2I. Goujaud (2OIO: I8). 
content and style, and these will be taken up briefly now.

One feature that stands out as unique to the chapters appended to the horticultural treatise is a certain penchant for quantification and measurements not found in the Memòria. Often found as a way to open a new chapter or section, they include phrases like "Al empeltar deu hom guardar dues coses..." (row I36), "E són tres maneres d'empeltar; la una manera es..." (row I45) and "Podar deu hom les vinyes en dos mesos de l'any, ço es en lo mes de dehembre e en lo mes de janer" (row I26). In another passage we note a similar concern for quantification when the author prescribes how many young grape plants (mayols) are needed to plant one mujada of vinyard. ${ }^{22}$ Another stylistic device found only in the non-horticultural material are the sweeping generalizations beginning with "Tot(es)..." as in the phrases "totes plantes de arbres o de vinyes se deuen fer..." (row I54, P), "tots arbres que hom vol plantar..." (row I54, $N$ ), "Tot podar se deu fer en la luna vella" (г27) and "Tot mayol de sarment se deu tallar..." (ıзо, V. No generalizations of this type appear in any of the chapters on horticulture.

One of the most salient aspects of the Memòria is its insistence on performing each horticultural operation in the correct lunar phase, either waxing or waning moon. Waxing moon is referred to as "luna nova" throughout the Memoria, but this locution should not be confused with the English phrase "new moon", when the moon's illuminated surface is not visible from the Earth. The entire period immediately following the new moon up until the full moon is "luna nova" in the Memòria, ${ }^{23}$ and this phrase (appearing as "lluna nova" and "luna nueva") occurs over 20 times. For the period immediately following the full moon, the phrase "luna vella" is used, and for the garden operations discussed in the Memoria this phase of the moon, the old or waning moon, is preferred over the "luna nova" by a ratio of 5:I. This imbalance results from the innovation, introduced by the Memòria author, of recommending a waning moon not only for planting root vegetables, as per ancient tradition, but also for vegetables cultivated for their aerial parts (leaves and stems), which traditionally are planted in the waxing moon. ${ }^{24}$ The logic at work in this innovation is that the "downward" influence of the waning moon works as a sort of braking action, preventing leafy greens from growing too fast and bolting, and this renders them more productive over a longer period of time. The phrase "l(l)una nova" (and "luna nueva") occurs only about 20 times in the Memòria chapters (rows I-I25 in Appendix I) while, because of the novel theory on the benefits of a waning moon on aerial vegetative parts, "l(1)una vella" (or "luna vieja") occurs well over I2O times in the same span.

However, being guided by lunar phase can entail much greater detail than merely knowing whether the moon's light is approaching fullness or declining toward the new moon. Some passages dictate not just waxing or waning phases, but also specify that garden operations be performed in certain quarters of the moon, as in the following example specifying second quarter: "les [carabaces] que voldreu transplantar las transplantareu en lo mes de abril, tambe en la lluna nova al segon quart”

22. Qui vol plantar huna mujada de vinya espessa ha mester mayols .v. mil .dc.xxv. (V f. 95v; Appendix, row I52).

23. This meaning of lluna nova is not registered in Alcover's Diccionari català-valencià-balear, although lluna vella 'the old of the moon' is (see next footnote).

24. This most basic of astrological tenets has been transmitted uninterrupted into modern times: "Sow all such seeds as root downward, as carrots, parsnips, beets, \&c. before the new of the moon" in Robert B. Thomas, The Farmer's Almanack (I799: f. 7 r). Even in $2 \mathrm{I}^{\mathrm{st}}$ century almanacs the same instructions appear year after year: "The light or new of the moon (increasing) is in the first and second quarters, and the dark or old of the moon (decreasing) is in the third and fourth quarters. Plant your above-ground crops in the light of the moon. (...) it is widely believed that planting crops that grow above the ground when the moon is waxing will produce rapid germination and growth. On the other hand, plant your below-ground crops in the dark of the moon when it is waning, but not during the last quarter" (Lucas McFadden ed., The Almanac for Farmers and City Folk, 20I7: 38). 
(Agustí f. 29r; Appendix I row IO2), and in these examples specifying third quarter:

[Cols se sembran en lo juny] en lluna vella, après que haurà fet lo ple (Agustí f. 23r; Appendix I row $5)$.

[Cols pera Pasqua] sembrareu (...) en lluna vella a la quarta haurà fet lo ple (Agustí f. 23v; Appendix I rows $27-28)$.

Les carabaces haveu de sembrar en lo mes de febrer après la lluna haurà fet lo ple (Agustí f. 29r; Appendix I row 94).

Les pastenagues se sembran en lo mes de juliol en la lluna vella, après que ha fet lo ple en lo matex quart (Agustí f. 27v; Appendix I row I20)

Los naps se han de sembrar en lo mes de juliol en la lluna vella, en lo quart ha fet lo ple (Agustí f. 28r; Appendix I row I2I)

[Les xaravilles] sembrareu en lo mes de Mars en la lluna vella, après ha fet lo ple (Agustí f. 29r;

Appendix I row I23)

All these examples, it will be noticed, come from Agustí I6I7, and this insistence on lunar quarters may constitute an elaboration of his own making and not a reflection of his source. Agusti's agricultural theory prioritizes such precision and is amply demonstrated in the complex graphic "Taula pera conexer lo temps en lo qual se pot sembrar moltes maneras de llauor de herbas" (in Agustí I6rz: f. I6v-ı8r).

Other passages prescribe agricultural tasks with even greater specificity - to be performed on certain days within a quarter of the lunar cycle - as in the following example: "Tot podar se deu fer en la luna vella. E deu se hom gordar que no pot hom en lo jorn que és plena car lo ple de la luna no val a les plantes si hom les tocha ans los nou. Mas pessat aquell dia és bo lo podar tota hora, e com pus prop és de la plena val més lo podar ( $B$, f. IIIr; Appendix I row I27); ${ }^{25}$ in this recommendation to prune vines only after the seventh day of the moon: "Emperò les vinyes velles deuen esser podades a cap de dos o de tres anys en la luna nova per renovellar emperò tota hora haia la luna mes de .vii. jorns. ( $B$, f. IIIr; Appendix I row I28); ${ }^{26}$ and these instructions to plant new vines in the full moon or in the following three days: "E quant seràs en la luna plena aquell dia o pasats dos o tres dies només en la vella lauos planta la vinya" ( $P$, f. 3 Ov; Appendix I row I3O). ${ }^{27}$ Other examples of specifying that agricultural tasks be performed only within a certain number of days before or after the new or the full moon can be found in rows 133 ("de la deena fins a la xv luna és millor"), I5I ("que sia passada quinta"), I53 ("La Luna hage .x. djes que sia girada tro en .xv."), and I54 ("en luna crexent com ha $x$ dies que és girada") and crop up in all five of our manuscript witnesses. Significantly however, there is only one example of this degree of lunar specificity in the Memòria, and then only in $P$ (row I23). The passage in question happens to be one of the few chapters (this one, on parsnips) that show no correspondence among the versions that carry it, and for this reason its place in the Memòria tradition may be safely questioned. In other words, outside this one dubious example there is virtually no interest shown in any of the chapters on garden vegetables in any manuscript witness of the Memoria toward specifying lunar phase beyond the broad "waxing" or "waning" periods of the moon. It is only after we pass on to the non-horticultural chapters that the prescription of lunar

25. 'All pruning should be done in the old of the moon, and take care to never prune in the day of a full moon because the moon's fullness is not good for working on plants but rather it harms them. But once the full moon is past any time is good for pruning, although the sooner after the full moon, the better'. Note that the same specificity is prescribed in $N$.

26. 'However, old vineyards should be pruned after two or three years in the light of the moon to reinvigorate them, but be sure the moon has been waxing for at least seven days'. Note that the same specificity is prescribed in $N$.

27. 'And when the full moon comes along, on that very day, or within the next two or three days but no later, that's when you should plant your new vines'. Note that the same specificity is prescribed in $B$. 
phase begins to specify lunar quarters and days.

This conspicuous shift in degree of specificity within lunar phases sets the non-horticultural chapters even further apart from the Memoria, since it is hard to accept that for one and the same author the attention to lunar phase should differ so markedly between horticultural tasks, on the one hand, and those pertaining to viticulture and arboriculture on the other. Yet there is still another aspect of agricultural astrology that distinguishes the horticultural from the non-horticultural chapters in our witnesses: while throughout the entire Memoria (Appendix I rows I-I25) the waxing moon is referred to regularly as "luna noua" as shown above, in the non-horticultural chapters this same phrase alternates with the synonymous "luna crexent". In the chapters dealing with vines and trees the ordinary term "luna noua" is found 20 times, but "luna crexent" also appears ( 7 times), and it does so in all five witnesses except $M$. In the Memòria chapters, on the other hand, "luna crexent" simply does not occur, except once in the same chapter of dubious authenticity on parsnips noted above in $P$ (row I23). This suggests that the copyists of the non-horticultural material were all following a distinct textual tradition, one that preserved to a greater or lesser degree what was perhaps the preferred phrase of the original.

There is further lexical evidence that the non-horticultural material found appended to the Memòria in $M$, $V$, and $N$ derives from a distinct source. Several broadly serviceable phrases that would be unsurprising to find in the Memòria simply do not occur there, while in the nonhorticultural passages and chapters, they contribute to a sense of distinct authorship. These include the emphatic "sens dupte", which occurs in the chapter on preserving fruit in $P$ (row I5O); the phrase aparellar-se de 'to be ready to', occuring in all five witnesses ${ }^{28}$ in a chapter on grafting (row I37); and the phrase cuytar a/de 'to be early in' in $P, B$, and $N$, as in the phrase "segons quels arbres se cuyten a brotar o tarden" ( $N$, f. $54 \mathrm{~V}$; Appendix I row I39) ${ }^{29}$ It is surprising that this phrase does not occur in the Memòria, since the latter places such a premium on early vegetable sowings and early-maturing crops.

Finally, we note a subtle shift in the cast of saints whose feast days mark the inception of many yearly agricultural tasks. The use of saints' and liturgical feast days as markers for yearly tasks is characteristic of many medieval vernacular writings on the subject, with universally observed feasts such as Christmas day and the feast of St. John the Baptist being among the most common. In Catalunya, the first such reference in an agricultural text comes in one of Ferrer Saiol's intermittent expansions on his translation (I385) of Palladius's Opus agriculturae, presented here as preserved in the Castilian version of ms. M: "E deues saber saber que en el mes de juñjo antes de sant iohan quando comjença el sol estiçi del estiu... tu deues colgar delos mas gruesos cabrafigos ensartados en vn filo a manera de paternostres \& fazer vna gujrlanda" (ІІ6v, Capuano I990: І26; italics in the original). Other examples can be drawn from other early Catalan texts on agriculture, such as this reference to Christmas in the Untitled Miscellany, "tallaras lo en hun colp lo mati de nadal"; the invitation to practice a sort of cabañuelas (Carril Ramos I988: I26-I27) or weather prognostication on the feast of Saint Peter, "Si vols saber dela carestia, o larguesa del any tu pendras esment lo dia de sent pere qui es en juny..." (Capuano 2009: II, I3); this assurance from the Capitols singulars deles llauors que deuras sembrar that nothing will damage spinach after Michaelmas "Spinax poras sembrar dela llauor vella y si non has de vella poras sembrar dela nouella remullada axi com damunt hauem dit, car no li noura res puix sent miquel sia passat" (96r, Capuano I998: 29); and this advice, from the Catalan translation of the Pelzbuch included in codex $V$ to plant on the feast of St. Lambert "y si vols quel arbre nos podreixqua plantal a xvij de setembre ques la festa de sent lambert" ( $V$,

28. Counting the cognate form aparejarse in $M$.

29. This verb phrase appears eight times across all three witnesses in Appendix, row I39. See also row I5I, footnote. 
IOIVI8-I9)..$^{30}$

The Memòria is no exception, with numerous tasks assigned on or around the feast of Saint John the Baptist ("sant Johan de juny" $B$ I2Or, $\$ 4$ in the present edition), Michaelmas ("sant Miquel"

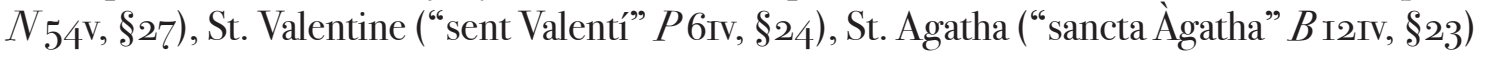
and others. The feast days of lesser known saints enjoying a more localized patronage occasionally appear as agricultural calendar markers as well, as in the example of St. Lambert in the Pelzbuch cited in the previous paragraph, perhaps reflecting the devotional customs of the writer's own community. This may be the case with the mention of the feast of St. Matthias, which is notably absent from the Memòria while figuring frequently in the non-agricultural material found appended to it in $M, V$, and $N$. The feast of the apostle St. Matthias, celebrated on February $24^{\text {th }}$, is referenced in $P, B$, and $N$ as propitious for grafting. In the Memoria, on the other hand, none of the eight operations prescribed for February mention this feast day..$^{3}$ This suggests that only for the author of the non-horticultural material was the feast of St. Matthias an important marker. The same could be said regarding the $3^{\text {rd }}$ century Sevillan martyrs Justa and Rufina, whose feast day (July I 7 ) is used to mark the inception of the sowing of turnip seed in two separate chapters in the Memòria, ${ }^{32}$ but July operations do not occur in any of the non-horticultural chapters so no contrast is possible in this latter case.

Finally, we note that both the Memòria and the non-horticultural material make recourse to local toponymy. In the purported title of the Memòria given in $A$ it is "Barchinona" (“...laqual memorja es presa dels mjlors ortolans de barchinona...”, f. Ir) while in the non-horticultural material we find two place names: "Valencia" in $B$ "hage de cep a cep .vii. palms de alna de Valencia a tots cayres a manera de taulell de stachs ( $B$ IIor, row I3O), ${ }^{33}$ and "Cathalunya" in $N$ "En Cathalunya poden les vjnyes de deembre de de [sic] Janer” ( $N_{5} 6$ r, row I26). Nothing conclusive can be made of this contrast in place names, considering that such references are constants in medieval Catalan agricultural texts ${ }^{34}$ and yet they may indeed reflect divergent geographical frames of reference.

In summary, we believe that important elements of style, lexicon and focus create a distance between the Memòria and the non-horticultural material that follows it in $M, V$, and $N$. This material, consisting in $M$ and $V$ of somewhat random phrases, and in $N$, of complete chapters on grafting, viticulture and similar non-horticultural concerns, in our view belongs at its source to a tradition totally separate from the Memòria, notwithstanding the title of the lost book from the Cartulary of Alart. We look forward to Joseph Gwara's edition of $A$, and to other possible future discoveries, to determine if these conclusions are justified.

To attempt to understand the socio-cultural context of the Memòria is a difficult undertaking, since in our witnesses the authorial voice is so refracted across many generations and the original plan of the work is so obscured by the various formats into which it has been forced. In $M$ and $V$, for example, we see a radical reduction of the full text into a series of snippets, where entire chapters are boiled down to a single phrase and the entire work, in this digest form, appears on barely two folio sides. In $N$ there is a seemingly arbitrary selection of chapters - just seven of the twenty-six

30. See the Aragonese version of this last example in Capuano 20II: r9ı.

3I. See rows 36, 38 (footnote), 83, 94, III, II2, II8, and I23. The only saints' days mentioned in the Memòria for February are Saints Agatha and Valentine.

32. One on obtaining head cabbage $\left(P_{57 \mathrm{~V}^{-}} 5^{8 \mathrm{r}}, \S_{5}\right)$ and one in an adage in the chapter on turnips "A sancta Justa e Rufina, sembra la tua nabina” ( $B$ I2Ir, $\left.\S_{20}\right)$.

33. "Space the young vines evenly apart seven handbreadths of the Valencian alna as when laying out a garden bed with stakes". The alna is a unit of linear measurement equivalent to about one meter (DCVB s.v.) The same passage in $P$ is "que aja de sep a sep ho $[$ sic] dotze pams ha tots quayres" (Appendix, row izo).

34. See for example, Capuano (I990: XVII-XIX; 2009: 4-5). 
that appear in $B$ - selected, perhaps, to meet the specific needs of the copyist's local audience. In $B$ and $P$, as indicated above, we find the Memòria to be incorporated into a larger composition with no indication that it could derive from a separate work. In Miquel Agusti's Secrets d'agricultura (I6I7) we find, thanks to Martí Escayol's discovery, that much Memòria material is hidden, with no attribution, alongside information taken from numerous other sources, written and oral.

And finally, in $A$, judging from the title rubric and the published descriptions of its contents, we confront a version of the Memoria that extends beyond horticulture and that recalls the "libre del art de ortalissa e de la podaho e de laurar continent en si dos sisterns de paper" reported by Emilie Goujaud from the Cartulary d'Alart (see above). Only in $M$, $V$, and $P$ are we addressed by a first person singular voice, but this voice sheds no light on the obscure origins of the treatise, and in no case does it belong to the original author. ${ }^{35}$ Still, it is not unreasonable to hope that other versions of this text remain yet to be discovered, and the expectation remains that Joseph Gwara's edition of $A$, with its strikingly descriptive title, may provide more clues regarding the genesis and historical context of the Memòria.

In the meantime, we are left to speculate on its origins and on the historical situation that gave rise to this treatise. To establish a terminus ante quem we must begin with $M$, which is the oldest of our witnesses if we accept Mario Schiff's assessment, who places the script of this MS in the final years of the $14^{\text {th }}$ century. ${ }^{36}$ The fact that it appears appended, along with numerous other lesser works on agriculture, to a copy of Ferrer Saiol's I385 Catalan translation of Palladius' Opus agriculturae $(O A)$ raises a number of questions. Was this digest form of the Memòria already circulating before it was appended to Saiol's work? Did Saiol himself append it to his translation? Did Saiol abridge it himself? It is tantalizing to posit that Saiol himself had access to the Memoria and that he may be the author of this abridgement, because we know from his own commentary to his translation of Opus agriculturae $\$ 7.9$ that he consulted "diuersos libres", more than one of which contained the weather prognostication technique that he attributes to "lalcabit moro" (V 73r). This technique, akin in purpose to the Salmantine cabañuelas (Carril Ramos I988: I26-I27), is inserted both within his translation of $O A \$ 7.9$ and again at $2 \mathrm{IOV}$, in one of the lesser unrelated tracts on agriculture, the "Untitled Miscellany" (Capuano 2009: I2), appended to Saiol's Libro de Palladio. If Saiol had access to the "Untitled Miscellany" and did not hesitate to insert it into his translation of Palladius, it is easy to imagine that he likewise had access to some, or all of the other lesser, unrelated tracts at the end of $M$ and $V$. Since we know that Saiol finished his translation in 1385 , it is not unrealistic to move our terminus ante quem back to this year.

In another line of reasoning, we can speculate that if the oldest version of the Memòria is the drastically reduced version in $M$, it seems likely that it had already existed in its full form for a significant period before it was abbreviated. This leads us to posit that its origins date to the middle of the $14^{\text {th }}$ century, and one final detail seems to corroborate this dating. The final two folios of BNE MS IO2II $(M)$ contain two chapters on the articificial pollination of date palms which to our knowledge remain unidentified and have so far elicited no critical interest. The second of the two chapters deals with how this pollination is to be carried out when the male and female flowers do not open at the same time. ${ }^{37}$ When the male flower is not open but the female flower is, the gardener is to drill a hole the size of a cruzado into the male spathe and extract the male flowers for pollination:

35. For examples in $P$ see Appendix, rows 36 and $3^{8}$ (footnote); in $M$ and $V$, row 24 . In $P$ this $y o$ is the voice of the compiler of BnF esp 29I, and can be found in several of the texts in this codex. In $M$ and $V$ it is the voice of the copyist grappling with a perceived inconsistency in the text.

$3^{6}$. Lluis Cifuentes i Comamala (private correspondence) has judged it slightly later, to the first quarter of the $5^{\text {th }} \mathrm{c}$. 37. The date palm Phoenix dactylifera is dioecious, i.e., the male and female flowers are on separate individuals. 
"sea fecho un forado de la grandeza de un cruzado en la fillola del masclo" ( $M$, fol. 245 r). The fact that the cruzado is a coin minted by Enrique II (died I379) and that, according to Mateu y Llopis, underwent a devaluation in $\mathrm{I}_{3} 6 \mathrm{o}^{38}$ is significant, considering that the same hand that copied these chapters on the date palm also copied the Memòria in the same codex. All these details taken together allow us to situate the composition of the Memòria, tentatively, around the middle of the I $4^{\text {th }}$ century.

Even with this approximate date of composition to guide us, we have found in the Memòria scant internal evidence that might explain or help identify the specific local forces that motivated its composition. We are obliged, therefore, to posit only in the most general terms the circumstances that might have surrounded its origin. The plague, which afflicted Barcelona and its environs intermittently during the latter half of the $4_{4}^{\text {th }}$ century would have created two parallel demographic pressures on agriculture during this period, one to replace the stricken and another to compensate for the dramatic depopulation via migration away from the region. ${ }^{39}$ Crop failures, the financial burden of frequent interregnal warfare, and endemic social unrest likewise characterize this period and would have necessitated maximizing agricultural output. These factors together could have created a demand among the literate landowners of Barcelona to seek out and document the best agricultural practices of the time. One passage in particular, on the casual intercropping of radishes and cabbages (see note I2I) suggests just such an audience. In the chapter on radishes ( $\$ 18$ of the present edition) the author clarifies that, unless one is marketing radishes, they do not need to occupy much space: "Ràvens no deu hom per ells triar terra carbaste a hom qui no $\cdot$ ls vol vendre que en los crestes dels solchs de les cols ne fasa hom plantar”. This suggests that a considerable portion of the intended readers may have been proprietors of small, self-sufficient holdings who would benefit from this space-saving technique. MS $N$ states explicitly that the provision of this vegetable for use in the home ("per a casa") is accomplished by planting them in just such spaces: "Per ràvens (...) basten per a casa (...) que $\cdot n$ mete hom en els crestes dels solchs de les cols" $(N$ $54 \mathrm{v}$; see Appendix I, row 6o). This intercropping detail and the phrase "per a casa" in $N$ provide strong support for the theory that the Memoria, with its brevity, its simplicity of structure and its straightforward, objective instructions may have been created for landed, literate families occupying the lands and farmhouses around the Barcelona city walls, i.e., for "un públic de propietaris rurals que valora l'autosuficiència de l'explotació agrària” (Cifuentes 2002: 89).

Whatever may account for its origins, the Memòria can take its place in the remarkably rich array of early agricultural writing in Catalan. Although of much more modest trajectory than contemporary translations from the Latin and Arabic agronomic traditions, the Memòria is significant precisely for its independence from prior models, and for the further evidence it provides for a flourishing school of agricultural writing in the Catalan speaking lands of the fourteenth and fifteenth centuries..$^{40}$

The base text used in our edition here is the text of the fifth chapter ("Libre quint o quinta part", f. IIgv) of the Libre o regla o ensenyament de plantar o senbrar vinyes e arbres ..., incipit f. IO4V) of MS 754 of the Biblioteca de Catalunya. We theorize that the compiler of the Libreo regla incorporated the Memòria as the fifth of his six part treatise. This incorporation is mirrored in $P$, where the Memòria material likewise appears as the fifth book ("Del libre quint paladi”, $\mathrm{f}$.

38. Felipe Mateu y Llopis (I946: 35 ). Note that $V$, which usually runs parallel to $M$, does not contain these chapters on the date palm. If $M$ is a translation from a Catalan source that did in fact contain them, this cruzado could conceivably be seen as a calque of croat, a term denoting various coins in circulation from the $13^{\text {th }}$ to the $5^{\text {th }}$ century (ibid. 35 ).

39. Outlined in Ruiz 2007: 42-44.

40. See Appendix II for an illustration of the independence of the Memòria from other major agronomic traditions. 
$5^{6 \mathrm{v})}$ of De agricultura paladi (3Ov). The attribution to Palladius is unfounded but common in the late Middle Ages, either because the writers truly believed they were copying Palladius's Opus agriculturae or because they wished to invoke its authority.

The editorial norms of Els Nostres Classics have been applied throughout the critical edition. Appendix I, however, presents a semi-paleographic transcription of each witness. 


\title{
${ }_{2}$ Critical Edition
}

\begin{abstract}
खi:
$\mathrm{E}$

nn nom de Déu sia. Assò és mamòria de les maneres de les laurons, de plantar e de sembrar e de pensar que hom deu fer a tota ortalissa, la qual memòria és presa dels milors ortolans de Barcelona, specialment qui pensen de orts qui $\cdot \mathrm{s}$ reguen..$^{4}$
\end{abstract}

[I] E primerament parlem de cols, per so com més ne usam que d'altre ${ }^{42}$ Primerament, de cols que són bones d'ivern, ço és, que hom les menge en aquell temps, sembra-les hom de mijant juny a mijant joliol ${ }^{43}$ en la luna vella, aprés que haurà fet lo ple, ${ }^{44} \mathrm{e}$ que y hage bon guaret feyt ab eres ${ }^{45} \mathrm{e}$ ab fems covinentment, no massa; e fan a reguar sovín. E deuen-se tresplantar de mijant agost a mijant setembre en la luna vella, e no spiguen ne són tan longues ${ }^{4}{ }^{6}$. E no volen molts fems, e al tresplantar molt més que al sembrar. E reguen-se tantost com són plantades e despuys de tres en quatre dies. ${ }^{4 z} \mathrm{E}$ [pu]ys, com hom veu que són preses, se deuen regar dues vegades la setmana ${ }^{48}$. E no $\cdot$ s deuen metre massa

4I. En nom de Déu... reguen] $A$, Ir. No other witness offers a title with such rich information regarding the genesis of this text.

42. E primerament... d'altre] $A$, Ir. The first person plural forms "parlem" and "usam" and the justification given here for treating cabbages before other vegetables suggest a control of the overall design of the text and convey the distinct confidence of authorship. None of the other witnesses attempt to preserve so faithfully such an authorial tone. This feature, among many others, is what makes $A$ so indispensable for a complete understanding of the Memòria text. However, Professor Gwara's long promised edition of $A$, in his private collection, has not yet been published, a fact which must define the present edition as provisional. The few references to $A$ that have been incorporated into the present edition derive solely from previously published excerpts; here, from the plate, published through the generosity of Prof. Gwara, in Capuano 2006: 24I. The fact that cabbages are treated first in the Memória may not be arbitrary, since the preeminence of cabbages among all other vegetables has a long tradition, as seen in Cato "Brassica est quae omnibus holeribus antistat" (Hooper-Ash I936: I40).

43. de mijant juny a mijant joliol] $V, 95$ r. Four of the seven witnesses prescribe the roughly one-month span of mid June to July for sowing cabbage seed. Those that fail to allow for a July planting (specifying June only) contravene the requirement of sowing in the waning moon, since a new moon falling too early in June would create an impractically short window for sowing. Most temporal prescriptions give a one-month span, whence this emendation.

44. aprés... ple] Agustí I6I7, 23r. Agustí I6 I 7 is the only witness that occasionally specifies lunar quarters. All the others are content to indicate simply whether the moon should be in its waxing or waning phase. Curiously, Agustí I626 (79) omits this phrase.

45. eres] $N, 54$ r. For a similar use in Castilian of era 'garden bed' see Capuano ig87. $B$ gives "fet ab vores" (II9v); literally, 'made with borders', i.e., in delineated beds.

46. e no... longues] $N, 54$ r. The benefit of planting and transplanting cabbages in the waning moon is explained here: in this phase its power to augment is at its lowest point, so the transplants are less apt to bolt or become leggy. Cf. Miquel Agustí i6rz: “Lo tresplantar també ha de ser en lluna vella, que en la nova posarian molt argull, y espigarian prest”. The same explanation is given a few lines below by $P$ and our base text $(B)$. Lettuce plants whose flowering stage can be forestalled by planting in the waning moon are thus "pus saboroses" ( $P$, fol. 59 r; see also $\left.\S_{12}\right)$.

47. tantost ... dies] $N, 54 \mathrm{r}$.

48. E [pu]ys... regar] $A$, Ir. We suspect that the original contained three prescribed waterings, all of which are attested if the seven witnesses are taken together, but that are conflated into one 
pregon car no se’n fan tant bé. Aprés, al cap de tres setmanas collar-les ab fems y terra. ${ }^{49}$ E per ço les deu hom sembrar e plantar en luna vella, ${ }^{5 \circ}$ que no spiguen tantost com ferien en la luna nova ni argullen tant de créxer en alt ni són tant longues com serien. E si per ventura hi romania planter que no fos bo ab les altres, planta-les hom avant tota hora que sia a plantar [e seran bones]. E seran bones a Pascha si seran tart plantades. E si les dites cols han la cama massa longa al plantar, façe-les hom que de aquella part hon deu venir l'aygua al reguar tenga l'ull, car vinent l'aygua les dreçe. ${ }^{5 \mathrm{I}} \mathrm{E}$ aquestes són bones en Quaresma y ans de Nadal. ${ }^{52}$

\section{[2] De cols de Pascha}

Si vols cols bones al Pascuor, sembra-les en l'agost o en la desexida de setembre fins per tot lo mes de octubre e de noembre, qui-s vol, emperò en la luna vella, e tresplant-les hom tantost que hom coneix que són bones a tresplantar, també en lluna vella, ${ }^{53}$ ab fems al plantar e al tresplantar, axí com havem dit en les altres, e gita del fem en la rahel de la col dos mostes ha cascuna. ${ }^{54} \mathrm{E}$ axí fan a rreguar. Mas aquestes fan a plantar spesses per ço com de tals n'i ha que spiguen, les quals fan $\mathrm{a} \cdot \mathrm{rrencar}^{55}$ primeres com hom les veu spiguar.

[3] [fol. I2or] De cols d'estiu

or two in each manuscript either by scribal error or by intentional omission. The first watering is upon setting out the plants, as seen in $N$; the second is every third or fourth day up to the point when the transplants have taken root, as in this phrase from $A$ ("com hom veu que son preses"); and the third is twice a week thereafter. Several witnesses, seeing little difference between the middle watering and the ensuing regime, conflate the latter two watering periods. See Appendix, row I4.

49. Aprés ... terra] Agustí r6iz, 23r.

5o. E per ço...vella] $A$, Ir.

5. This difficult passage elicits an editorial intervention in $V$ : "Mas yo dich que més val que•ls giren les rahels a l'aygua" (95r). After all, it makes little sense to lay a sprawling plant with its leaves (and not its roots) toward the irrigation flow. For a full discussion of this passage and this editorial comment, found only in $V$ and $M$, see Capuano 2014: 7-8.

52. E aquestes... Nadal] V, 95r. Cabbages (Brassica oleracea) are generally harvested in the cold weather at the end of the growing season, and can withstand considerable frost, whence this observation to harvest and consume cabbages from this late sowing (performed between June and July) from Christmastime through Lent (December-March). For an even later harvest, see the next section "Cols de Pascha" and for an earlier harvest, see "De cols d'estiu" below. It will be noticed that for each of these sowings the time until harvest is roughly six months. All three of these chapters refer to the cultivation of leaf cabbage and not to the head-forming cabbage variety (Brassica oleracea var. capitata), which is treated below in "Cols de capdell". Andrés Laguna, refering to head cabbage as repollo murciano, provides an overview of the four varieties of cabbage known in $6^{\text {th }}$ Castile (Dubler 1955: 204).

53. també... vella] Agustí I6I7, 23v. Cf. “en luna vieja," $M$, 2IIv.

54. e gita... cascuna] $P, 57$ r. Mosta is a variant form of ambosta "the amount that can be taken between the hands' (See DCVB s.v. ambosta).

55. a·rrencar] Agustí r6r7. This reading is confirmed by $M$ (“y sy brotonaran fazen a descabesçar") even though $B$ and $P$ present "fan a regar". The latter is in error since here the objective is not to water but to thin out the plants that bolt (i.e., that send up flower stalk). 
Cols d'estiu que són bones en veremes e al setembre sembra-les de mig febrer fins $a^{56}$ mijant març en la luna vella e tresplanta-les hom sempre que són bones de tresplantar en luna vella. E volen molt fems al sembrar, mas al tresplantar ne volen molt més, axí com és dit de les altres. Axí mateix del reguar. E seran bones en venemes. ${ }^{57}$

\section{[4] De cols de Sicília}

Si vols fer planter de cols de Sicília, sembra-les a .viii. dies ans o aprés de sant Johan de juny e ti-les a prop de reguar. E com sien grans tresplanta-les e guarda que y fira lo sol tot lo dia..$^{8}$

\section{[5] De cols de capdell.}

De cols de capdell se volen ni pus ni més sembrar com les altres cols, però hull-te mostrar en qual manera, no tenint de aquella sement, en qual forma ne poràs fer prodoyr. Primerament, tu cavaràs hun troç de terra, tanta com de les dites cols volràs plantar o sembrar, e aquella faràs molt bé femar. E quant vinga a la festa de santa Justa e Rufina, qui és ha .xvii. de juliol, sembraràs aquella terra de sement de naps, molt espesa, tant que los huns estigen mesclats ab los altres, e rega'ls dos o tres vegades, emperò guardar en lo sembrar que la terra estiga de sahó, e no $•$ ls culles. E com vendrà en la luna plena de febrer com una exada tallant escabesaràs tots aquells naps e sembra sements de cols de qualsehulla natura. E puys sia cuberta aquella sement de terra [e] fem ben podrit, hun dit en groç, e rega-les en covinent e, despuys, un dia per altre ruxa-les ab algun vexell en asò bo fins a tant que sien exides, e despuys dona'ls aygua de dos en dos dies. E quan seran granetes, tresplanta-les e seran cols copades o de capdell. 59

[6] De erbolam de Pascha. ${ }^{6}$

56. de mig... a] Agustí I6I7, 23v.

57. e seran... venemes] $V, 95^{\text {r. }}$

58. tot lo dia] $P, 57 \mathrm{v}$.

59. $P\left(57^{\mathrm{V}-58 \mathrm{r})}\right.$ is the only witness containing this chapter. The anomalous use of first person singular ("hull-te mostrar") may suggest to some that this is a later accretion, to others it may show the primitive immediacy of authorship. We find the marvelous nature of the process described to be a significant departure from the norm in the Memòria traditions discovered so far. In addition, the seven month growing period prescribed here (July to February) seems suspect, for it far exceeds the average span of days to harvest for turnip (50-6o) when planted for its own sake; despite the crowded sowing this planting would most certainly run to seed well before February. Nonetheless, the verb escabesaràs 'you shall decapitate' (i.e., you shall drag a sharp hoe across the soil cutting away the green growth from the roots), as preposterous as the overall process may seem, does allow us to posit just such advanced maturity as the intended state of the crop. In addition, this chapter shares with another quite typical Memòria section (also related to turnips) its use of the feast of Saints Justa and Rufina as a point of reference in the yearly cultivation calendar, thus permitting it to cohere somewhat to the whole. For other references to this feast day, see "De naps" in $P, 6 \mathrm{IV}$ and in $B$, I2Ir, and Appendix, row I2I.

6o. Erbolam de Pascha is 'Easter salad mix' i.e., a mix of the seeds of various vegetable greens sown together for harvest and consumption around Easter time. In Miquel Agustí r6I7 this chapter 
Arbolam lo qual és bo al Pascuor, ${ }^{6}$ ço és, spinachs, colills, bledes e almolls e altres frasques ${ }^{62}$ sembra hom en la entrada de giner, e no y guarda luna qui no $\cdot \mathrm{s}$ vol. E volen molts fems e reguar sovint, e no $\cdot$ s tresplanten. ${ }^{63}$

\section{[7] De erbolam encara ${ }^{64}$}

Altre ${ }^{65}$ erbolam sembre hom per semblant mijant març, e ab molts fems y regar sovint ${ }^{66}$ e no s'hi guorda $[$ sic $]$ luna ni·s tresplanten. Tambe podreu fer altre ${ }^{67}$ erbolam, ço és, blets e bledes ab alguns grans d'espinachs ${ }^{68}$ sembra hom a la entrada de abril, e $\cdot$ s fan a femar e a rreguar e no·ls cal tresplantar ni guardar luna.

is entitled "Arbolam de pastors" (24r). We speculate that Agustí encountered in his Memòria source either the antiquated form pascor 'Easter' (found also in B pascuor, irgv), or perhaps even more likely, a copyist's error of pastor 'shepherd' for pascor, since misreadings of $-c$ - for $-t$ - are ubiquitous in many manuscripts of the period. In either case, in his attempt to make sense out of an unfamiliar word, Agustí mistakenly interpreted this salad mix to be typical not of Easter time but of shepherd's fare, whence his error "de pastors", his elaboration "y de companya", and his marginal note "Ortalisa per los pastors y moços". This misinterpretation results in "Arbolam de pastors, y de companya, fareu en la entrada del mes de janer...” (24r). In his Castilian translation of his own text this error solidifies itself further in the opening lines of the same section on arbolam: "Para la familia de la casa de campo, como són trabajadores, y pastores, hareys un arbolam en el principio del enero..." (8Ir). In $M$, the other Castilian translation of the Memòria, no reflex of the word erbolam occurs, and no rubric heads up this chapter.

6I. At this point we get the strongest evidence yet that a commentator has intervened in the Memoria transmitted in $P$, because in this witness we find here a somewhat confusing and unnecessary succession of two lists of the greens making up an arbolam 'mesclun, mix of salad greens'. It seems quite clear that an original author would not have allowed such a succession, which comes about because the copyist or commentator of $P$ first feels the need to gloss arbolam by giving a list of typical greens making up such a mix, and then returns to the text to faithfully copy the list of greens that comprise the specific arbolam presented in this chapter, i.e., the Easter arbolam: "Erbolam de Pasqua se entén la ensalada, ço és, morrito[r]t, ruques, julivert e altres erbes qui són bones per fer ansalada quant encara espinachs, bledes e altres frasques sembre hom a la entrada de jener..." ( $P, 5^{8}$ r; italics added to emphasize the gloss). Of the herbs mentioned in the gloss in $P$, morritot (morritort) is garden cress (Lepidium sativum); ruques (singular, ruca) is rocket or arugula (Eruca sativa); julivert is parsley. The greens making up Easter arbolam are spinach, colills (tender young cabbage leaves), bledes (Swiss chard, Beta vulgaris var. cicla) and almolls (orache, Atriplex hortensis). $M$ and $V$ conflate the sowing times for this and the arbolam (or erbolam) treated in the following chapter by prescribing both January and March or April sowings. However, the chapter title for this erbolam in our base text $B$ clearly distinguishes this mix of greens from other combinations of greens by their consumption around Easter time.

62. e altres frasques] $P, 58$ r. Frasques 'sprigs' (singular, frasca; DCVB: "branqueta prima; cast[ellà] ramita") here appears to mean 'salad greens' in a general sense.

63 . Found only in $M(2 \mathrm{I} 2 \mathrm{r})$ is the phrase "las espinacas solas quieren mucho estiercol" (only spinach requires a lot of manure). Rather than incorporate this phrase into our edition, we have chosen to consider it an anticipation on the part of the compiler of this codex of the treatment of spinach cultivation, which does in fact call for ample manuring (see chapter on spinach below).

64. De erbolam encara] $P,{ }_{5} 8 \mathrm{r}$.

65. Altre] Agustí I6I7, 24r. In our base text $(B)$ all three types of erbolam are treated in the same chapter and no labels are used to distinguish them from each other.

66. e regar sovint] Agustí i6r7, 24r.

67. Tambe... altre] Agustí I6I7, 24r.

68. ab... espinachs] Agustí I6I7, 24r. The copyist of the base text $(B)$ slips here, giving "spinachs e alguns grans". 
D’aquí avant no sembra hom spinachs fins a ${ }^{69}$ migant agost.

[8] De spinachs

Spinachs menja hom en l'Avent de Nadal. E haquests se volen sembrar ${ }^{70}$ mijant agost ab la luna vella ab molts fems, e fan a reguar a vagades com hom coneix que $o$ han ops. E aquests spinachs són bons de ivern [e] en Quaresma.

[9] De spinachs encara ${ }^{71}$

Encara, altres spinachs sembra hom mijant setembre tro mijant octubre en la luna vella. E regua'ls hom com ho han mester, e sembra'ls hom ab molts fems. E són bons de tota Quaresma, si és alta o baxa. ${ }^{72}$

[Io] De spinachs encara ${ }^{73}$

Alguns ortolans diuen ${ }^{74}$ que la lavor vella és millor que la de l'any mateix ${ }^{75} \mathrm{e}$ fan axí: meten la lavor en huna senalla e cusen-la, e puys, ab huna corda,$^{76}$ meten-la en hun pou en l'aygua e lexen star .vi. o .vii. jorns. En aprés, descusen-la e meten la lavor dins en altra ${ }^{77}$ senalla; puys tornen cosir la senalla e meten-la en lo pou en guisa que no toch en l'aygua e stigue-y .iiii. o .v. jorns. E lavors la lavor és grillada, e sembra-la hom ab molts fems e ixen tantost..$^{8}$

[II] [fol. I2Ov] De letugues

69. fins a] $P, 5^{8 \mathrm{r}}$.

7o. menja... sembrar] $P, 5^{8 r}$. The base text $(B)$ does not mention the practice of consuming spinach during Advent, although it does use the same phrase ("en l'Avent de Nadal") in the chapter on lettuce that follows.

7. encara] $P, 5^{8 \mathrm{v}}$.

72 . The harvest of this fall sowing of spinach lasts throughout Lent, whether the lenten season falls early (alta) or late (baxa). Cf. "Altes o baixes, a l'abril les Pasqües" (DCVB s.v. Pasqua).

73. encara] $P, 5^{8 \mathrm{v}}$.

74. Both the base text $B$ and $P$ make direct report here of what "some farmers say" ("alguns ortolans diuen...") regarding saving spinach seed and regarding the method they use ("e fan axí") of pre-soaking the seed, in this way reinforcing the claim made at the outset of the work (in $A$ ) that the agricultural practices of the Memòria are indeed taken from the best farmers of the region ("és presa dels milors ortolans de Barcelona, specialment qui pensen de orts qui-s reguen", $A$ Ir). Germination rates of viable spinach seed can vary widely depending on soil temperature, so presoaking is recommended and widely practiced in modern horticulture as well.

75. Agustí (I6I7) confirms this preference for aged spinach seed: "En açò fa molt al cas la edat de la llavor, (...) perquè, com tinc dit, que lo porro, cogombre, llimoners y toronger venen més prest de llavor nova que de vella y, al contrari, lo julivert, espinachs, morritort, orenga, seliandre venen millor de sement algun poch vella” (23r, italics added for emphasis).

76. ab huna corda] $P, 5^{8 \mathrm{v}}$.

77. altra] $P, 5^{8 \mathrm{v} \text {. }}$

78. e ixen tantost] $P, 5^{8 \mathrm{v}}$. 
Les letugues primarenques sembra hom mijant hagost o de ${ }^{79}$ setembre tro mijant octubre en la luna vella ab molt fems e fan a regar com ops ho han. E tresplanta-les hom en l'Avent de Nadal ab fems en la luna vella, ${ }^{80}$ e regua-les hom de .viii. en nou dies per amor de les jelades. ${ }^{8 \mathrm{r}}$

\section{[ı2] De letugues encara ${ }^{82}$}

Algunes letuges sembra hom de noembre tro a mijant deembre e tresplanta-les hom de giner. Al sembrar e al tresplantar guarda hom la luna vella perquè ne són pus saboroses. E met-hi hom ${ }^{83}$ molt fems, reguant quant ops o han. ${ }^{8_{4}}$

\section{[I3] De alls}

Alls planta hom mijant dehembre ${ }^{85}$ en la luna vella en terra ben cavada e guaretada menys de fems, e fan a reguar en loch de reguiu en manera que $\cdot$ s pugen regar ${ }^{86}$ de .viii. en .viii. jorns. E si no $\cdot 1$ s planta hom de dehembre, plante'ls hom de giner en la luna vella, mas més valen los primarenchs de dehembre per ço com la neula ${ }^{87}$ de maig no $\cdot 1$ s pot noure per ço com són ya crescuts. E no fan a plantar clars, ans deu haver de hun a altre .iiii. o .v. dits, no pus. ${ }^{88} \mathrm{E}$ quisvol bé pot sembrar entre los alls primarenchs alguns grans de spinachs e fan se fort bells, e de letugues e fanse belles. Si vols que.ls alls no grillen, fes que si los alls són plantats en luna vella, arranqua'ls en luna nova, e si són plantats en luna nova, arranqua'ls en luna vella. E nota com los plantaràs volen ésser solament hun gra d'all, e de gra en gra axí fan

79. hagost o de] $P, 5^{8 \mathrm{v}}$.

8o. vella] $P, 5^{8 \mathrm{v}}$.

8I. per... jelades $] P_{5} 8 \mathrm{v}$. $P$ is the only other witness that allows for sowing late season lettuce in August and the only one that establishes an explicit connection between watering and protection against frost ("regar-les has (...) per amor de les jelades"). Maintaining proper soil moisture can prevent damaging heat loss in the light frosts of Advent (December).

82. encara] $P, 59$ r.

83. guarda... met-hi hom] $P, 59$ r.

84. Following this chapter and preceding the next on garlic, $P$ inserts $\left(59^{r-v}\right)$ two long anomalous chapters attributed to Solomon the Wise ("lo savi Salamó"), one on how to grow an unusually large calabash and another on the propagation of mint by means of fly feces. We have opted to omit both since they appear to be accretions by the compiler of $P$. Transcriptions of these two chapters are offered in our synoptic edition (Appendix, row $5^{\mathrm{I}}$, footnote) and in Martí Escayol 2OI2: I23.

85. $P(6$ or $)$ and $B$ are the only witnesses that prescribe mid December for planting garlic; the other witnesses prescribe mid November. Agustí r6I7 (27v) contrasts the late planting in January with a November planting two months earlier.

86. en manera... regar] $P$, 6or.

87. $B$ has "luna" and $P$ "lluna" (6or), both in error; here low cloud cover and haze ("neula" 'fog' in the other witnesses; "niebla" in $M, 2$ I2r) are associated with May weather patterns and are blamed for the slow maturation of garlic planted in January.

88. o... pus $] N(54 \mathrm{v})$. There should be a space of about a hand's breadth between each garlic clove, an interval that is here considered a thick, not thin sowing ("no fan a plantar clars"). This is consonant with the spacing prescribed in $P$, "fan a plantar clars en modo que aja huna gran mà de la hu a l'altra" (6or). 
a plantar. ${ }^{89}$

\section{[I4] De scalunyes}

Si vols fer scalunyes, hages una ceba e tall les rahils e aprés leve'n la terça ${ }^{90}$ part de la ceba envés lo grill, en rodó, e fica-li grans de alls, .iii. o .iiii., e cobre-u de terra e hauràs scalunyes. ${ }^{91}$ Ítem, en aprés altre manera: prend[r]e les scalunyes, una mota, e lexa-les devall terra e en lo mes de maig trau-les de la mota, fe'n de cascuna scalunya sa part e planta cascuna per si e fer s’à de cascuna scalunya huna mota. $9^{2}$

89. E nota... plantar] $P, 6$ or. To close out this chapter on garlic, $P, 6$ or-6ov adds instructions on how to make garlic taste like mustard. We suspect this to be another accretion by the compiler of $P$ (see note 84 ) because of the anomalous instance of second person possessive ("e puys planta ton all") not found elsewhere, and because of this compiler's penchant for marvels and manipulations of nature (such as here, the insertion of a mustard seed into a garlic clove). Here is the full text: "E si per ventura volies fer de huna cabesa d'alls que vingués axí groça com lo puny o pus groça, pendràs lo gra de l'all e foradar-l'as ab huna estaqua que sia molt prima, però que lo forat no li pas, e puys dins aquell forat metràs hun gra de senapi e puys planta ton all e farà's molt gros. Però nota que sempre la sua sabor tira al senapi, però és molt bella cossa”.

9o. terça], $P 6$ ov; $B$ terra.

9r. This chapter on growing "scalunyes" by inserting garlic cloves into an onion qualifies as one of the "marvels of nature" of the dubious sort such as are so often encountered in medieval scientific literature. As such, it seems somewhat out of step with the objective horticultural practices of the rest of the text. However, our understanding of the passage hinges on the meaning of this "scalunyes" (s.v. ascalunya in $D C V B$ ). The term may here refer to immature onions, i.e., the greens or tender stems of the onion before bulb formation (in English, "scallions" or "green onions"), since, after all, the "grill" or shoot that emerges from a stored onion is indeed a type of "green onion". However, DCVB s.v. ascalunya gives the meaning 'shallot' ("Planta liliàcea: Allium ascalonicum L. (Cat[alunya]); cast[ellà] escaluña, chalote"). Botanically, the shallot is considered a variety of onion (Allium cepa var. aggregatum) which, like garlic, has bulbs consisting of numerous cloves; this similarity may have given rise to the process described. More likely, scalunya in this chapter refers to chives (Allium schoenoprasum) as in the $4_{4}^{\text {th }}$ century Sinonima ("Ynule galiçe, i. escalonas de çebollas muy pequennas", in Mensching r994: I6I), since the use of the words mota 'cluster, tuft' in $B$ and mata 'clump' in $P$ suggest the latter species' habit of growing in bunches (see also next footnote). Nonetheless, the process described is fraught with difficulty from a botanical standpoint, since garlic cloves (Allium sativum), even if inserted into a fresh onion, cannot themselves transform into separate species such as Allium schoenoprasum (chives) or Allium cepa (green onion). Whether the insertion of garlic cloves stimulates growth from an onion bulb that is somehow reminiscent of green onions is a matter for the horticultural laboratory. Note that $P$ has a different version of these instructions, although the process described is the same: "Si vols fer escalunyes, pendràs una seba e talla-li molt bé les rahels e aprés despulla-la en manera que la terça part ne vaga en aquella despulla, però que la seba començ a grillar, e despulla-la tant fins que lo grill te romanga redó, e puys pren grans d'alls e fiqua’ls en aquell grill en tant que n'i metes tres o quatre e cubri-los de terra, e axí auràs escalunyes" (6ov).

92. $P, 6$ ov implies that it is by means of the first process (inserting garlic cloves into an onion that has had two-thirds of its bulb peeled away from the core) that a gardener may achieve a cluster of "escalunyes": "E puys, com ne tingues una mata ne tendràs moltes, ço és, que tingues soterrada aquella planta dejús terra e com vinga en lo mes de maig trau-les e departex-les de cap en cap e puys planta cascun cap per si e de cascun cap auràs una planta. Cosa provada”. However, in $B$ the corresponding passage constitutes a second set of instructions separate from the first, applicable to those who wish to propagate "escalunyes" from an already established cluster. 
[I5] De porros e cebes

Porros e ceba porrera ${ }^{93}$ sembra hom en l'entrant de març en la luna vella tro mijant març, e no se poden cremar per lo fret, ${ }^{94} \mathrm{y}$ també de més primarenchs, en lo mes de janer y febrer. Per haver llavor de ells per tenir-ne en lo estiu, se plantaran en lo abril, maig o juny; per tenir-ne en lo hivern, se plantaran en lo agost, setembre y octubre. 95

La ceba fa a sembrar clareta per ço que faça més groça e bella $\mathrm{e}^{96}$ meta millor mata, e volen bon guoret e no massa fems, e fan a reguar de .ii. en .ii. dies la setmana o més si ops o han. Emperò, los porros volen molts fems. ${ }^{97} \mathrm{E}$ dien alguns que hom deu cavar la llevada, e ben plana e sembrada de bon fem ben podrit, e despuys sia homplit aquella llevada de aygua e ab aquella aygua sembra la llavor de la seba e vendran molt millor..$^{98} \mathrm{E}$ fan a tresplantar los porros, axí com la ceba porrera, de mijant agost fins mijant setembre ${ }^{99}$ en la luna vella.

Los porros volen molts ${ }^{\mathrm{IoO}}$ fems al tresplantar, mas a la ceba porrera ${ }^{\mathrm{IOI}}$ no cal fems, mas vol terra bé cavada. Com tresplanta hom los porros volen que hom los planta spessos, que no hage de hun a l'altre més de hun dit, ${ }^{\mathrm{IO2}} \mathrm{e}$ volen aygua de .iii. en .iii. dies tro sien presos.

La ceba deus tresplantar en maig fins migant lo mes de juny en luna plena e aprés la met dejús terra ab molt fem mesclat ab la terra ${ }^{103} \mathrm{No}^{\mathrm{N}} \cdot \mathrm{s}$ vol tresplantar tan spès mas bé vol que hom la plant spes covinentment. Mas puys són preses volen-se reguar .ii. vegades la setmana, [e] les primeres vegades se volen entrecavar molt. ${ }^{104}$ $\mathrm{E}$ los solchs dels porros sien ben amples ${ }^{\mathrm{I05}} \mathrm{E}$ de hun solch a altre hage un bon

93. ceba porrera] $V, 95$ r. $B$ gives "cebes e porella" ("Porros e cebes e porrella sembra hom..." I2OV), undoubtedly an error for cebes porreres, a variety of onion with a leek-like shape similar to the calçot, which is also known as ceba porrera (Vallès et al. 20I4: 260) because it too is elongated and does not form a bulb. It is of interest to the history of the calcot that the ceba porrera in this chapter, like the calçot, is hilled in order to more thoroughly blanch the tender stems. This chapter thus creates a distinction between onions without bulbs ("ceba porrera") and onions with bulbs ("ceba rodona"), the subject of the following chapter.

94. e no... fret] $P$, 6ov. Although onions are frost hardy when mature, seedlings cannot survive a frost.

95. y també... octubre] Agustí i6r7, 26r.

96. faça... bella e] $P, 6$ ov.

97. Emperò... fems] $V, 95^{\mathrm{r}}$.

98. E dien... molt millor] $P, 6$ Ir. The horticultural sense of llevada is akin to a raised bed or seedbed, i.e., a portion of ground, usually rectangular, destined for planting one or more vegetable crops. DCVB: "En els bancals, llenca de terra més o menys llarguera on sembren llegums sense fer cavallons (Massalcoreig); llenca d'hort entre dos cavallons, que es rega d'una vegada (Calasseit)".

99. los porros... setembre] $V, 95$ r.

IOO. molts] $V, 95$ r.

IOI. We have supplied "ceba porrera" here in keeping with the contrast in progress in this chapter between leeks and bulbless onions. In $B$ a blank space is left in this place ("Mas a la [blank] no cal fems").

IO2. $P$ recommends a less dense spacing (“e fes per manera que de hun porro a l'altre aja dos o tres dits", 6rr), which is much more in line with modern practice.

Io3. deus tresplantar... ab la terra] $P, 6 \mathrm{Ir}$.

IO4. les primeres... molt] $P, 6 \mathrm{Ir}$.

IO5. y los solchs... amples] $V, 95^{\mathrm{v}}$. As seen above, the author alternates between instructions for leeks and instructions for bulbless onions. As $B$ switches away from the transplanting regime for 
forch o una mà de una a l'altra e seran belles. ${ }^{106} \mathrm{E}$ quisvol pot plantar cols e ràvens e fan-se molt bé entre los porros. E los porros fan a entracavar [fol. I2Ir] e cubriri ${ }^{\mathrm{IO}}$ ab terra.

La lavor dels porros e de les cebes pot hom axí tenir: que là hon són tresplantats leix hom hun solch o dos, aytants com hom se vulla, los quals spiguen, e leix hom assahonar la lavor, e que hom l'astoig bé. ${ }^{108}$

[ı6] De cebes rodones de salvar

Ceba rodona de salvar sembra hom mijant giner en luna vella per ser primarenca, y se'n sembra de febrer y de mars, ${ }^{\text {109 }} \mathrm{e}$ en guaret ben fet ab molts fems. E rega’ls hom sovín e tresplanta-la hom com és creguda. Per guardar-la de fret y gelades fareu los remeys que tenim dits. ${ }^{\text {Iо }}$

cebes to that required by porros, he begins with the dubious phrase "E fan a plantar present [sic] los porro", which is omitted here.

Io6. un bon forch... belles] $P, 6 \mathrm{rr}$; forch is a linear measurement equal to the distance between the thumb and index finger fully extended ("Mida equivalent a la distància entre el cap del dit polze i el del dit índex, tan separats com sia possible" DCVB s.v. forc.)

IO7. In $B$ we find cullir, which we have corrected to cubrir 'to cover'. The full text of $B$ here is "E los porros fan a entracavar $[$ sic $]$ e cullir $[$ sic $]$ ab terra axi com los porros $[$ sic $]$ ". The final phrase "axi com los porros" represents another error on the part of the copyist, who has apparently omitted the last example of how the cultivation of bulbless onions compares with that of leeks.

Io8. Agustí I6I7 includes a detail not found in the other witnesses regarding the timing of leek plantings for seed collection: "per haver llavor de ells per tenir-ne en lo estiu, se plantaran en lo abril, maig o juny; per tenir-ne en lo hiuern, se plantaran en lo agost, setembre y octubre" (26r), but this note may derive from Agustí's personal experience or "obra personal" (as in Luna-Batlle 20I3: 69).

Note that at this point $P$ adds a paragraph on stimulating the swelling of onion bulbs and on preventing stored onions from sprouting that seems to represent a later accretion. The fact that the passage appears at the end of the chapter reinforces this judgment; the use of the first person prounoun in "yo he vist", the formulaic "e és provat" and the contrived borrowing from medicine of the cauterization process are features not prominent anywhere else in the corpus: "yo he vist que com són axí com la gruyxessa de hun bou les descalsen de la terra e fan-se’n molt groses, e és provat. E si vols que no grillen axí prest, com les enforcaràs per voler-les salvar leva'ls ab un gavinet totes les barbes, ço és, les rahels. E puys met hun ferro en lo foch e com serà molt e ben vermell, crema allà hon an estat les barbes, $\mathrm{e}$ puys met-les a salvar. E açò val molt [per] què no grillen axí prest” (fol. 6rr-6rv).

Io9. per ser... mars] Agustí ı6I7, 26r. Another detail offered by Agustí i6iz relates to the usefulness of fertilizing onions with manure tea made from pigeon and chicken dung. However, the presence of vocabulary uncharacteristic of the Memòria, such as samal (a receptacle for transporting goods on horseback) and the verb femar 'to fertilize'; and the very mention of specific animal sources for the manures prescribed suggest strongly that this passage is not original to our text and likely comes from Agustís own experience: "és molt bo destrempar ab aygua ab una samal fempta de coloms o de gallina y femar-ne la terra" (26r).

IIO. per guardar-la... dits] Agustí I6I7, 26r. The phrase "que tenim dits" we suspect is a vestige of the primitive organization of the Memòria, because Agustí has not mentioned previously any measures that protect young onions from frost, nor is there any such passage in the previous chapter on leeks, a closely related crop with similar susceptibilities. In fact, nowhere in this division of his work ("Secrets dels horts, y de les herbas y hortalisas de menjar. Cap. IIII", 2Ir) is there any mention of precautions to be taken against cold weather. 
E decontinent que hom veu que és bona a tresplantar, en abril o en maig-que quant mes primarenca és, ${ }^{\text {III }}$ mes val- fa a tresplantar en la luna vella, emperò lo Pal.ladi diu que en lluna que sia nova. ${ }^{\text {I2 }} \mathrm{E}$ fan a plantar ${ }^{\mathrm{II}} \mathrm{com}$ pus som pot hom, ${ }^{\text {II }}$ per ço com millor ceba met, e basta-li que solament sia cuberta de terra la caboça. ${ }^{\amalg 5}$ No vol fems al tresplantar, mas vol-ne al sembrar axí com damunt havem dit. E fa a reguar, pus és tresplantada, de .iii. en .iii. dies e de entracavar hun dia la setmana. Guardar-se deu hom com la regua que la hora sia clara, car fort li nou com se regua ab leig temps e no se'n fa tant bella ni tant bé.

Qui vol haver de la lavor, planta de les cebes grosses, de les pus belles que trops, mijant noembre e faran lavor. E leix-les hom assahonar e stoig-les hom tro al temps que les deu hom sembrar. E no hix pus és sembrada tro a .xxx. dies, ans stà dins terra los dits .xxx. dies. ${ }^{\text {I6 }}$

\section{[I7] De cebes rodones}

It is possible, but seems unlikely, that Agustí could be referring back to a previous chapter in his Secrets d'agricultura..., such as "Secrets per a saber en quin temps se han de sembrar los horts o

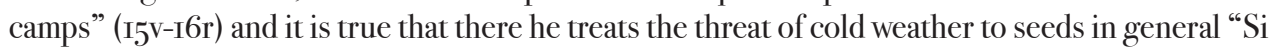
emperò tindreu temor que per respecte dels frets y gelades [las sements] se cremen, podreu-las cobrir ab palla y desota posareu vergues o canyes o serments entravessades, perquè tingan la palla mofla y anayrada" (Agustí ı6r7: I6r) but this reference seems too far removed in topic and page number to warrant an allusion such as this "que tenim dits". Barring this possibility, whatever these "remeys" may have been they have been lost in all the extant witnesses. See $§ 23$ for a similar instance of an empty reference (footnote I42).

III. que quant mes primarenca és,] Agustí I6I7, $26 \mathrm{v}$.

II2. $V$ has the contradiction "Emperò lo Pal-ladi diu que en lluna vella que sia nova" which we have corrected on the basis of $M$ "Empero el Palladio dize que en luna que sea nueva" (2I2v), which may be a reference to Palladius $\$ 3.24 .4$ "si minuente luna serantur, tenues et acriores proueniunt, si crescente, robustae et saboris umecti”.

At this point Agustí I6I 7 adds instructions on shaving off the roots of the onion transplants before setting them in the soil, along with the watering regimes to be used subsequent to this removal: "Quant la transplantareu, tallar-los totas las raels perquè ne fassen de novas, y regareulas. Si no• Is llevau las raels, quant las haureu plantades dexareu de regar-las deu o dotze dias y en estos dias las raels se'ls moriran, y aprés regau-les y posaran raels novas, y se faran molt millors" (26v). There is no sign of these instructions in any other witness, and their improbability and complexity suggest that they are a later accretion, so we have omitted them entirely.

II3. fan a plantar] Agustí I6r7, 26v.

II4. Luna-Batlle (2OII: 60) and Capuano (2OI4:39) misread the phrase "com pus som pot hom" ( $\left.B_{\mathrm{I} 2 \mathrm{Ir}}\right)$, correcting it unnecessarily and illogically to "com pus com pot hom" (as much as one can). The transcription of som 'shallow, close to the surface' should be respected as it stands, giving "com pus som pot hom" 'as close to the surface as one can'; som here is the adjective "superficial, poc profund” (DCVB) as is clear also from the corresponding passage in Agustí I6I7 "y fan a plantar molt somas, que basta la cabeça sia cuberta de terra" (26v).

II5. Luna-Batlle (2OII: 6o n. 93), citing the second edition of the DCVB, for the form cabossa from the Maestrat and from Northwestern Catalonia gives the meaning 'the thickest part of the onion' ("la part més ampla de la ceba").

II6. Agustí I6I7, 26v, adds the following, likely from his own experience: "Si voleu que las cebas se serven y que no $\cdot$ s grillen ni·s podrescan fins en lo mes de maig o de juny, procurau cullir-les lo mes de juliol o de agost o de setembre, quant estigan en sahó, dia axut y lluna vella, que no•s colpejan. Després les posareu en lo sol a axugar, que no·s banyen, y les posareu dins de una bota desfonsada de un cap, a sostres, posant a cada sostre cals viva, com si era sal. D'esta manera se salvaran com tinch dit". The curing process prescribed here involves instructions and vocabulary that depart from the usual style of the Memória. 
Ceba redona aquella que hom menge tendra al Pascuor ${ }^{\mathrm{II}}$ sembra hom en Agost ab ràvens ${ }^{118} \mathrm{e}$ són bones a sopar.

\section{[I8] De ràvens}

Ràvens se poden plantar per tot l'any, mas més valen aquells qui són plantats en lo mes de març y de joliol ${ }^{\text {п9 }} \mathrm{e}$ no volen fems, mas volen terra ben cavada e bé tova. Ràvens plantats en lo mes de juliol valen més e són millors de l'any. Los uns e los altres se volen regar a vegades. Ràvens no deu hom per ells triar terra $\operatorname{car}^{120}$ baste a hom qui no $\cdot$ ls vol vendre que en los crestes dels solchs ${ }^{122}$ de les cols ne fasa hom plantar.

\section{[ı] De pastanagues}

Pastanagues sembra hom en juliol en luna vella, aprés que ha fet lo ple en lo matex quart, ${ }^{122}$ en terra ben cavada pregon e ben guaretada; no volen fems,${ }^{123}$ mas volense reguar sovín e no·s tresplanten, y no $\cdot$ s volen sembrar molt espeses perquè se pugan fer ben grossas y belles, y estas seran bones en la Quaresma. També ne podeu sembrar en la primavera, pero són millors las de la tardor. Si voleu que la rael sia bella y grossa, convé que los aneu llevant las fulles per aclarir-les. ${ }^{124}$

[20] De naps

II7. We have inserted "al Pascuor" based on $M$ (“cebolla redonda para pastor..." (2I3r), where pastor is undoubtedly a scribal error for Pascor (see note 6o).

II8. For another example of interplanting (radishes with cabbages), see next chapter.

II9. y de joliol] $V, 95$ r.

I2O. car] $N, 54 \mathrm{~V}$. The sense of this difficult phrase is that it is not necessary to reserve a plot ("triar terra") specifically for radishes ("per ells "), since the typical homestead does not consume them in quantities as high as would be needed for market. See next note.

I2I. crestes... solchs] $N, 54$ V. $B$ gives "en los camps de les cols" (I2Ir) and Agustí I6I7 "als solchs de las cols, porros, y dels espinachs" (27r). The horticultural meaning of cresta from $N$ is given in $D C V B$ as "perfil superior de la terra que la rella talla o deixa en llaurar" and here may refer to the strip of earth that is turned up onto the turf lying adjacent to a garden plot when the plow makes its first pass in preparation for the cultivation of a crop. Cabbages are much slower to mature than radishes, so interplanting both crops would result in an economizing of cultivable space, and if we accept the reading from Miquel Agustí r6 7 , we see that such casual intercropping was used with leeks and spinach also. Herrera (I5I3) confirms the same practice with Swiss chard from his sources: "Puedenlas bien sembrar entre las otras ortalizas que no tienen necessidad de tener apartado por si lugar, sino o por los sulcos o entre las eras" (IO5v). The mass cultivation of radishes destined for market is quite another matter, and is described fully in Palladius $\$ 9.5$.

I22. aprés... quart] Agustí I6I7, 27v-28r, i.e., in the third quarter. This degree of specificity regarding the proper lunar phase for planting is not at all common in any of the manuscript witnesses, suggesting that this detail may be original to Agustí.

I23. Agustí I6I7 claims just the opposite: "vol la terra... ben femada". However, it is well known that the application of manure immediately before sowing is detrimental to the root development of carrots.

I24. y no $\cdot$ s ... aclarir-les] Agustí I6I7, 28r. Thinning carrot leaves allows for better air flow and sunlight, discouraging disease. This passage is unique to Agustí and may be original to this author. 
Naps sembra hom en juliol en luna vella axí com les pastanagues, e sie a la entrada del mes de juliol, per ço com més val que sien primarenchs que tardans; e aço se enten de tota ortaliça, que més val que sia primarencha que tardana. E diu l'eximpli del antich: ${ }^{125}$ "A sancta Justa e Rufina, sembra la tua nabina", ${ }^{126}$ la qual festa és .xvi. dies ${ }^{127}$ a la desexida de juliol.

Lo nap vol la terra ben fangada y novament moguda, y la llavor no ha de ser de més de tres anys, que si és més vella no produex sinó cols. ${ }^{128}$ Axí, quant los sembrareu, procurareu de sembrar-los ab terra prima, mesclada ab lo gra, perquè no $\cdot \mathrm{s}$ sembran massa espeços. Si a cas són massa espessos, los aveu de aclarir. Per sembrar-los, haveu de esperar que la terra sia estada regada primer, o del cel o manualment, perquè seran millors, y no los sembreu en lloch de hombra, perquè la hombra los és molt contrària, si no és que la terra sia bona y fèrtil. ${ }^{129}$

Alguns los sembren en la terra hon han arenquats alls e sebes, que s'i fan molt bons e ben saborosos e groços e no són corquats. Axí matex se planten $\mathrm{o} \cdot \mathrm{s}$ sembren les pastanagues. ${ }^{\mathrm{I} O}$

\section{[2I] [fol. I2IV] De xerevies}

I25. del antich] $P$, 6Iv.

I26. The preposition "a" in the phrase "a sancta Justa e Rufina" can be interpreted to mean 'by' this date; i.e., turnip seed should be planted not on but by the feast of Justa and Rufina. In $P$, however, the sowing period prescribed is a nineteen-day window, from nine days before until nine days after the saints" day ("Si vols sembrar naps, sembrar-los has .VIIII. dies abans de senta Justa e Rufina, qui és a .XVII. de juljol, o .VIIII. dies aprés”, $P$, 6rv). The more literal reading of this passage (to sow turnip on either of these two days, either nine days before or nine days after) is unlikely because of its impracticality and arbitrariness, both of which are uncharacteristic of the Memòria.

I27. The meaning of ".xvi. dies a la desexida de juliol" is "sixteen days before the end of July"; counting from August $\mathrm{I}^{\text {st }}$, the tally falls on July ${ }_{\mathrm{I}}$, the feast day of the $3^{\text {rd }}$ century martyrs Justa and Rufina, just as given in $P$ : “...santa Justa e Rufina, qui és a .xvii. de juljol...” (6rv). However, the base text $(B)$ gives ".vii. dies ala desexida de juliol", which we have corrected to ".xvi. dies..." to make the date fall on the $z^{\text {th }}$. This same witness $(P)$ gives a variant form of the horticultural proverb featured in this chapter, incorporating carrots into the prescription: "diu lo exemple de l'antich: 'A santa Justa e Rufina, planta pastanages e napina”" (6rv). Agustí r6r7, on the other hand, introduces a completely different adage "lo bon nap, per sanct Jaume ha de ser nat" (28r), i.e., by the feast of St. James, which is eight days later (July $25^{\text {th }}$ ), your turnip seed should have sprouted. Agustí I626 repeats this saint's day in yet another (Castilian) variant of the theme "El buen Nabo, por Santiago tiene cabo" (p. 9I). Turnip seed planted in the warm soil of July will germinate in as few as four days.

I28. Despite the botanical error of this statement, turnip greens and leaf cabbage are indeed remarkably similar in appearance. On the close relationship alleged between turnips (Brassica rapa var. rapa) and cabbages (Brassica oleracea), see the passage from $P$ above $(\$ 5)$, where cabbage seed, sown in the same bed where thickly sown turnip tops have been shaved away from their roots, supposedly develops into head cabbage. Conversely, $\mathrm{I} 6^{\text {th }}$ century writers such as Gabriel Alonso de Herrera (fol. Io8r), citing Ibn Wafid and Palladius (\$3.24.7); and Andrés Laguna (Dubler 1955: 205), citing Dioscorides, warn that cabbage seed four years old or older produces not cabbage but turnips. In the $4^{\text {th }}$ century Geoponika the degeneration is mutual "Turnip seed produces cabbage in the third year, and vice versa" (Dalby 20II: 259).

I29. Lo nap... bona y fèrtil] Agustí I6I7, 28r. The phrases used to treat precipitation and other growing conditions in this passage are quite dissimilar from any other witness and suggest that this passage may be original to, or adapted by, Agustí.

I30. Alguns... pastanagues] $P, 6 \mathrm{Iv}-62 \mathrm{r}$. 
Xerevies se sembren en la luna vella de giner aprés ha fet lo ple. ${ }^{\mathrm{II}} \mathrm{E}$ deuen-se sembrar en terra freda ben cavada y femada, ${ }^{132}$ que $\cdot 1 s$ fems sien bé podrits. E deuen-se sembrar clares per ço que millor se façen. També ne podreu sembrar tots los mesos de l'any, emperò las del mes de mars són las millors y de més virtut, y estan tot lo any en la terra. ${ }^{133}$ Ítem, si tu has dels grans ${ }^{134}$ de les xarovies, que són rahils de les xerovies, e si és massa gros parteix-lo en algunes parts e cascuna part mit-la devall terra, sol que tinga dos dits de terra desús, e hauràs de les xerevies. $\mathrm{E}$ volen-se fer en loch fret e que no $\cdot 1$ s do massa lo sol. ${ }^{135}$

\section{[22] De xufes}

Xufes fan a sembrar en maig. Deuen-se collir en agost. Deuen ésser reguades en la hora que n'hagen mester. Ítem, volen ésser sembrades en bona terra, car com en millor terra seran sembrades, millors seran. ${ }^{\mathrm{I} 36}$

\section{[23] De carabaces}

Carabaces sembra hom mijant giner tro a mijant febrer, ço és, que planta hom lo gra en la luna nova. ${ }^{137}$ E met-hi hom molt fems, bé mig palm de alt, e sobre los fems mit los grans e cobre'ls hom ab una poqua de terra mesclada ab los fems, que sols estigan cuberts un través de dit. ${ }^{13} \mathrm{E}$ han ops loch hon toch lo sol tots dies e

I3I. aprés ha fet lo ple] Agustí I6I7, 28r.

I32. ben... femada] Agustí I6I7, 28r.

I33. També... terra] Agustí i6r7, 28r.

I34. $B$ gives "grams" which we have corrected. The word gra (plural, grans) commonly refers to 'seed' or 'pip' (as in the chapter below on calabash), but here refers to small pieces of the parsnip root ( $D C V B$ s.v., meaning 4, "tros petit de qualsevol matèria...") which can be used as cuttings as an alternative method of propagation.

I35. Only two other witnesses include a chapter on planting xirivia ('parsnip'), and neither coincides with $B$. It is significant that in $P$ the Memória material has come to an end; its chapter "De plantar cherevies", along with another on artificially coloring and seasoning fruit ("De donar color e sabor") immediately precede the Catalan translation of Ibn Wafid's Tractat d'agricultura in this codex (here titled "De agricultura: altra obra" 62r), which suggests that both these final chapters in $P$ are later accretions from a different source altogether. In Miquel Agustí the passage on parsnips (28r) coincides with $B$ only in one detail, that they should be planted in a waning moon; with $P$, not at all.

I36. No other witness includes a chapter on the $x$ ufa 'yellow nutsedge, tiger nut sedge' (Cyperus esculentus), source of the tuber used to make orxata.

I37. For the first time in this text, a waxing moon ("luna nova") is prescribed. This is in keeping with the general rule of thumb that crops developing underground should be planted in the waning moon (when the moon's power to cause downward growth is at its highest), and those developing above ground should be planted in the waxing moon, when the moon's power to augment is greatest. The author of the Memòria made a deliberate departure from this rule when he prescribed a waning moon for leafy vegetables (cabbages, spinach, lettuce, mesclun, etc.), reasoning that the diminishing moon would forestall bolting (upward growth) in these crops and thus prolong their usefulness. In the case of calabash, there is no need to forestall flowering, whence the return to the traditional lunar planting prescription.

I38. que sols... dit] Agustí I6I7, 29r. 
no y pusque toquar gran vent. E si fahie gran fret com deuen exir, cobri-les hom ab draps o ab stores en guisa que 1 fret no y mogue. E fan a reguar de .iii. en .iii. jorns, e com pus sovín les regue hom, pus tost se fan, e si l'aygua era calenta del sol, hi valria més.

Los grans de les carabaces fan a remullar ab ayga tèbea, quisvol, e seran pus tost exides de .iiii. o .v. dies, e com seran remullades plant-les hom en la manera desusdite. Ops és que ls grans de les carabaces, ans que sien mesos a remullar, sien ben sechs, e si no eren ben sechs, seque'ls al sol e puys remulla'ls axí com demunt és dit. [E diu lo] eximpli: "per sancta Àgatha sembra ta carabaça, si vols que bé te fasa”, la qual festa és a .v. ${ }^{139}$ dies de febrer. Emperò, les carabasses novelles que voldreu transplantar ${ }^{1 / 0}$ fan a tresplantar en lo mes de abril, en la luna nova, hon toque bé lo sol, ab molts fems, y fan a regar sovint, ${ }^{\mathrm{I} / \mathrm{I}} \mathrm{y}$ si fa fret o gelades, les cubrireu ab draps o estores o ab los remeys [que] tenim dits. ${ }^{1{ }^{12} 2} \mathrm{E}$ planta-les hom axí: fa hom hun clot que hage bé dos o tres palms o més d'ample e de pregon hun palm e mig, e fa-li hom entorn lo clot orle de terra e puys, en mig loch, posa hom molt fems mesclat[s] ab terra e fa-li hom un mont alt en mig del clot e plante-y hom tres planters de carabaces. E açò fa hom per ço que lo clot omple hom d'aygua al reguar de la mota de mig, per tal que aygua no toch a l'ull de la carabaça, car menys ne valria, e regue-les hom de .iii. en .iii. dies, de sesta, ab calor, tro que sien ben preses. E si per ventura fahia gran fret, cobre-les hom.

\section{[24] De carabaces primarenques ${ }^{143}$}

Si vols haver carabaces primarenques abans de sent Johan de juny, ajes bon fem d'estable que sia ben podrit he solegat e mesclat en bona terra graça. Allí sien

I39. The feast of St. Agatha, $3^{\text {rd }}$ century virgin and martyr, is universally celebrated on February $5^{\text {th }} . B$ gives February $\mathrm{IO}^{\text {th }}$, in error.

I40. que voldreu trasplantar] Agustí I6I7, 29r. Note that in addition to the direct sowing of calabash prescribed above, the transplanting of seedlings was likewise practiced.

I4I. hon... sovint] $V, 95^{\mathrm{V}}$.

I42. y si fa... dits] Agustí I6I7, 29r. The phrase "los remeys [que] tenim dits" ("the countermeasures we have mentioned”) is strong evidence that this passage from Miquel Agustí is original to the Memòria. Since no remedial measures have yet been mentioned in this chapter (titled "Secrets de les carabaces y cogombres"), Agustí must have been copying a text that contained this phrase. The reference here is to the safeguards to be used against cold weather damage to seedlings, given in the prior passage on direct sowing: "cobri-les hom ab draps o ab stores". However, these instructions do not appear in Miquel Agustí, rendering illogical the phrase "[que] tenim dits".

I43. The three witnesses that give instructions for early calabash diverge significantly. The base text chooses to abbreviate this chapter ("sembra-les segons que en lo capítol desús és dit”, $B$, I2IV), and because $P$ does in fact repeat much of the sowing instructions of the previous chapter, our emendations are based on this source. As always, these emendations incorporate the text of $P$ verbatim, except that here we have intentionally omitted the phrase "com pose en lo capítol del fem" (6IV; "as I stated in the chapter on manure"), in which the compiler of the codex refers back to the chapter "Del millor fem" (55r) of a previous text in the codex ("De agricultura Paladi" 3ov). Miquel Agustí's instructions for early calabash (Agustí I6I7: 29r-29v) bear no resemblance to those of $B$ or $P$, but rather involve sowing seed in pots and moving the pots each evening back into the house to protect them from the cold, echoing instructions given in the ancient Geoponika (Dalby 20II: 257). 
sembrades les carabases lo jorn de sent Valentí, qui és a .xiiii. de febrer. E sien plantades en loch de sol, per mesura, e sien regades sovint. ${ }^{\mathrm{I} 44} \mathrm{E}$ com seran exides no les regues ab aygua, mas regua-les ab leyt de vaques o de ovelles o de cabres, e hauràs carabaces molt primarenques. Ha voler-les hun poch pus tardanes, se volen sembrar en lo mes de març, com aquell mes sia la mare de les semençes. ${ }^{\mathrm{I} / 5}$

\section{[25] De melons, albudeques, cíndries, cogombres e albergínies}

Cogombres, melons, cíndries, albudeques e albergínies sembra hom mijant febrer e per tot lo dit mes, ${ }^{\mathrm{I}}{ }^{6} 6 \mathrm{ab}$ luna nova, e ab molts fems, bé [fol. I22r] mig palm d'alt o més, axí com les carabaces, e no fan a cobrir guayre, mas tan solament que los grans sien cuberts de terra mesclada ab fems. E volen-se reguar sovín, de .iii. en .iii. dies. E volen que lla hon són sembrats los grans que’ls hi toch lo sol tot lo dia o la major partida. E tresplanten-se en abril. ${ }^{\mathrm{I} z} \mathrm{E}$ volen se reguar de .iii. en .iii. jorns, exceptat quant ${ }^{\mathrm{t} 4^{8}} \operatorname{los}$ melons e les albudeques e les cíndries començen a madurar no $\cdot$ s volen regar ${ }^{1 / 49}$ si donchs no vehia hom que mester ho haguessen. E pot-los hom sembrar en loch que no les cal tresplantar, si hom no·s vol. E si per ventura fahia fret, abrich-les hom axí com les carabaces.

La lavor dels melons e cíndries e de albergínies, de cogombres e de albudeques, ans que hom les sembre, deu ésser remullada ab aygua .ii. o .iii. dies. Les albudeques, cogombres, melons, cíndries e albergínies deuen esser sembrades per tot febrer, e ha spay deles dites dues lavors ales altres dues .xx. o .xxx. jorns. Specialment, lo millor temps de sembrar albudeques o melons o cíndries és entorn la festa de sancta Maria de març, en la manera que dit és. ${ }^{150}$

I44. abans de sent Johan... regades sovint] $P$, 6rv.

I 45. Ha voler-les... semençes] $P$, 6 rv.

I46. The manuscript witnesses seem to misrepresent the timing for sowing these warm-weather crops. The original probably read "sembra hom de mijant ffebrer e per tot lo mes de marc".

I47. E tresplanten-se en abril] $V, 95^{\mathrm{v}}$.

I48. quant] $V, 95^{\mathrm{v}}$.

I49. començen a madurar no $\cdot$ s volen regar] $V, 95^{\mathrm{v}}$.

I5O. It is unclear in this passage which of the five crops are contrasted by the phrase "E ha spay entre les dites dues lavors ales altres dues" (i.e., there's an interval between [the sowing of] the first two crops and the other two) because one of the five seems to be inexplicably omitted here, and even if we emend the passage to read ".... les altres tres" it remains unclear which sowings should precede the others. However, based on the final sentence, it is possible that the author is lumping together the sowing done for melon, watermelon and albudeques (a variety of insipid watermelon, Citrullus lanatus var. citroides) and another sowing, 20-30 days earlier, for eggplant and cucumbers. The aqueous nature shared by the three former favors this interpretation. The text seems to allow that, even with a twenty-day lag between the two plantings, all five crops may be sown in February, except that the former (the three melon types) prefer a later sowing in March. Agustí I6r7 gives a separate chapter on growing melons all year that does not correspond to any other witness: "Secrets dels melons de tot lo any y de las albudecas. Albudecas y melons de tot lo any sembrareu com està dit ab los altres melons, per lo que són tots de una espècie y axí volen lo matex regiment, sinó que estos maduran un poch més en la mare en lo camp, y per ço los melons, quant veureu que seran grossos [y] grochs, los cullireu sens colpejar; las albudecas, quant veureu alguna grogor entre la gran verdor que té-y, los servareu ab palla de ordi o penjats al sostre fins los voldreu menjar" (3or). 
[26] De sembrar juhivert

Si sembres lavor de juhivert en lo mes de març no spiguarà tro en lo segon any..$^{15}$

\author{
[27] Faves
}

Faves comunament se planten $0 \cdot \mathrm{s}$ sembren a sant Miquel. Qui les vol primerenques planta-les hom en agost o en setembre, en la primera setmana. ${ }^{152}$

I5I. Parsley, being a biennial, always flowers in the second year regardless of the month in which it is planted. The brevity of this chapter suggests that it was a later accretion. It is unique to our base text $B$, and seems out of place: following the pattern of treating together all vegetables grown for their aerial parts (as shown by Capuano 2015: 62), this chapter would be expected among the first eleven vegetables grown for their above ground parts. However, its placement here may represent an acknowledgement of the dual purpose of the parsley crop, which in the medieval period was grown for its root as well as its leaves. In this regard see Libro de medecina llamado macer (Valladolid I527, f. I4v3-6) and Alonso de Herrera Herrera's Obra de agricultura: "Del perexil. (...) muchos lo siembran por amor de las rayzes y los tales o lo siembren ralo o lo traspongan quando chico" (I5I3: II8r).

I52. Faves. Faves... setmana] $N$, 54v. The feast of St. Michael the Archangel (Michaelmas) is September 29. This chapter on fava beans occurs immediately following the two on lettuce in $N$ $(54 \mathrm{~V})$, and this proximity to the chapters on vegetables seems to buttress its place in the Memòria. However, $N$ is the sole witness containing this chapter. Ordinarily, agricultural writings of the period treat fava beans and other legumes not as vegetable crops but together with grains as field crops, as demonstrated in a separate work in codex $V$, an untitled agricultural miscellany: "Tota sement que·s dega sembrar per tal que faça gra, axí com ordi, forment, avena, faves, siurons, pèsols, fesols y altres sements, se deuen sembrar en lluna crexent..." (Capuano 20o9: I4). Ancient writers on agronomy extoll fava beans and other legumes for their virtue as a green manure in preparation for field crops, as in the Opus agriculturae of Palladius (§ I2.I), and in the Tratado de agricultura of Ibn Wafid: “El .ix”. capítulo es de senbrar el trigo e la çevada e las legunbres. Deven senbrar el trigo en la buena tierra e la çevada e el lino en la mediana e las havas e los garvanços en la tierra húmida e las legunbres tienplan la tierra..." (5v). In our corpus, the chapter "Secrets delas favas" in Agustí r6r7 (83v) appears in his Chapter 22 "Dels secrets de la cultivacion dels grans, dels forments y llegums en terras cultivades” (77r), far removed from his treatment of vegetable gardens, and thus far from the sections where Martí Escayol (2008) first discovered the embedded Memòria material. Closer in time to several of our witnesses, "Capitulo XVIII. De las hauas" (I6v) in Gabriel Alonso de Herrera’s Obra de agricultura (I5I3) presents instructions on cultivating fava beans (along with lentils, peas, and other legumes) not in Book IV on vegetable gardens (fol. 99r) but rather in Book I, which treats, inter alia, "toda manera de pan y legumbres" (fol. 3v). It should likewise be recalled that like grains, fava beans and other legumes were ground into flour in the medieval period and this flour was used as both food and medicine, further aligning favas with field crops. Nevertheless, we find in this chapter on favas no features of style or language divergent from the style and language of the Memòria, so we have included it in the present edition. We do so under the assumption that alongside large-scale field sowings, fava beans and other legumes had a place in the homestead garden as well. However, our witnesses provide little evidence that the cultivation of any other legumes (such as beans and peas) were contained in the Memoria. Although chapters on beans and peas and other legumes appear in Agustí and in $P$, in both they find their place far removed from the Memòria material: in Agustí i6 I 7 some fifty folios later under the heading "Dels grans que se fa pa" $(83 r)$ and in $P$ in the section that precedes the Memória material, titled ( $\left.5^{\mathrm{IV}}\right)$ "Del libre quart paladi". We interpret this placement as evidence that legumes were not a part of the original Memòria, with the possible exception of favas. 


\section{${ }_{3}$ English Translation}

[I] In the name of God, Amen. This is an account of the cultivation customs, of planting and of sowing and other considerations to be applied to all vegetables, and this account has been taken from the best gardeners of Barcelona, especially from those who deal with irrigated gardens.

We begin first with cabbages, since we use them more than any other vegetable.

First, regarding cabbages for the winter, that is, that are consumed then, you should sow them from the middle of June to the middle of July in a waning moon right after it has been full, and in well-worked soil separated into beds and with the proper amount of manure, not too much; and water them often. They should be transplanted from the middle of August to the middle of September in a waning moon so they won't bolt or become leggy. The amount of manure should be moderate, much more when transplanting than when sowing. Water them as soon as they're planted and every three or four days thereafter. Later, once you see they're established, they should be watered twice a week. Don't set them too deeply or they won't do so well, but after three weeks hill around them with soil and manure. The reason why they should be planted in a waning moon is so that they won't bolt as soon as they would in the new moon, or get leggy or have long straggly stems. If some of your cabbage sets aren't as vigorous as the others transplant them first ahead of the others. A late planting will be ready by Easter. If your plants are leggy when it's time to set them out, transplant them with their stems on the side that the water comes from when irrigated, and they'll straighten up with the moisture. These cabbages are good for Lent and for the Christmas season.

\section{[2] Easter cabbages}

If you want cabbages that are ready by Easter sow them in August or toward the end of September through October and November if you like, but do so in a waning moon, and transplant them as soon as you see they're ready, also in the waning moon. Use well-rotted manure when setting out the plants and also when transplanting, as we said above regarding the previous planting, adding two double handfuls of manure to the roots of each one. Water at once. These cabbages should be planted thickly since there will be some that bolt, and these should be pulled up as soon as you see them start to form the stem.

\section{[3] Summer cabbages}

Summer cabbages that are ready by vintage time and by September should be sown from the middle of February to the middle of March in a waning moon, and transplant them when they're big enough also in the waning moon. They want lots of manure in the seedbed but even more when transplanting, as we said about the previous cabbage plantings. Water them the same way also, and they'll be ready by vintage time.

\section{[4] Sicilian cabbage}

To make Sicilian cabbage sets, plant the seed the week before or after St. John’s Day in June, and be 
sure they are watered regularly. When they're big enough transplant them and be sure they have full sun all day.

\section{[5] Head cabbage}

Head-forming cabbage should be sown exactly like other cabbages, but if you don't have any seed, I want to show you how you can produce it. First, hoe up a plot of soil big enough for the amount of head cabbage you want to plant and manure it well. On the feast of Saints Justa and Rufina, which is the $\mathrm{I}^{\text {th }}$ of July, plant turnip seeds in that plot, sowing them so thickly that the seedlings grow entangled with each other, and water them two or three times. But be sure when you sow the seed that the soil is just right. Don't thin them; and on the full moon of February scrape away all those turnips as with a sharp hoe, and sow cabbage seed of whatever type you want. Cover the seed with about a finger-width of soil and well rotted manure and water it thoroughly. After that, sprinkle them every other day with a watering can until they have sprouted. Thereafter, water them every two days. When they're big enough transplant them and they'll grow into head cabbages.

\section{[6] Easter spring mix}

Spring mix for Easter time, that is, spinach, young cabbage, chard, orache and other greens should be sown in the beginning of January, and there's no need to observe lunar phase. They need lots of manure and frequent watering. Transplanting is not recommended.

\section{[7] Other types of spring mix}

Another spring mix can be sown in the middle of March in the same way, with lots of manure and frequent watering, and there's no need to observe the lunar phase, nor should they be transplanted. Yet another mix, of purple amaranth and chard mixed with a few spinach seeds should be sown in the beginning of April. Manure it and water it. Transplanting is not recommended, and lunar phase doesn't matter. There is no further sowing of spinach after this until the middle of August.

\section{[8] Spinach}

Spinach is consumed during Advent. This planting is done in the middle of August in a waning moon with lots of manure. Water it occasionally when it looks like it's drying out. This crop can be harvested in winter and in Lent.

\section{[9] Another spinach planting}

Another spinach planting can be made from the middle of September to the middle of October in a waning moon. Water as necessary and and use lots of manure with the sowing and they will be ready for the entire lenten season, whether it comes early or late.

[Io] More on spinach 
Some gardeners say that old seed is better than the current year's seed, and this is what they do: they put the seed into a basket, stitch it closed and then lower it on a rope into a well and leave it in the water for six or seven days. Then they undo the stitches and put the seed in another basket and sew it up and put it in the well again but this time just above the water level and they leave it there four or five days more and by then the seed has sprouted. They sow this seed with lots of manure and it emerges right away.

\section{[II] Lettuce}

Early lettuce is sown in the middle of August or September until the middle of October in a waning moon with lots of manure. Water as needed and transplant it during Advent with manure in a waning moon and water every eight or nine days to protect it from the frost.

\section{[i2] More on lettuce}

Some lettuce plantings are made from November to the middle of December with transplanting in January. When sowing and transplanting, be sure to do so in waning moon because they are more flavorful that way. Add lots of manure and water as needed.

\section{[I3] Garlic}

Garlic is planted in the middle of December in a waning moon in well worked fallow soil without manure. In irrigated locales, provide for watering once a week. If not planted in December, they can be planted in January in waning moon, but the early December planting is better because the cloudy conditions of May can't slow their growth since they're further along by then. Don't space them too far apart; rather, there should be no more than about a handbreadth or slightly less between each plant. If desired, it's good to plant a few spinach seeds in among the early garlic because they will do very well, and lettuce, which likewise will flourish. To keep garlic from sending up shoots in storage, those planted in a waning moon should be dug up in a waxing moon, and those planted in a waxing moon should be dug up in a waning moon. When you set them out plant just one garlic clove at a time, that is, each clove is planted separately.

\section{[I4] Scallions}

If you want to make scallions, take an onion and cut away the roots and then remove a third of the upper part of the onion in a circle around where the leaves emerge and insert there three or four cloves of garlic, cover it with soil and you will have scallions. Another way to get scallions is by taking a clump of them and leave them under soil. Then in the month of May take each scallion away from the bunch and plant each one individually and each scallion will in turn produce a cluster.

\section{[I5] Leeks and Onions}

Leeks and long onions sown in a waning moon from the beginning to the middle of March will escape frost damage. For an earlier harvest sow in January and February. To obtain their seed for a summer sowing, plant them in April, May or June; if for a winter sowing plant them in August, 
September and October.

Onions should be sown rather thinly so they'll swell more and have better foliage. They need well-worked soil without too much manure, and they should be watered every other day, more often if needed. Leeks, on the other hand, do require a lot of manure. Some say that if you hoe a leek bed so it's good and level and thoroughly mixed with good, well-rotted manure, and then drench the bed with water and sow the onion seeds in that moisture they will do much better. Transplant both leeks and long onions from the middle of August to the middle of September in a waning moon.

Leeks prefer plenty of manure when transplanted, but long onions don't, although they do need well-worked soil. When transplanting leeks space them thickly so that there's no more than one finger's width between them, and they need watering every three days until they're established.

Onions should be transplanted from May until the middle of the month of June in a full moon, setting them below the surface of the soil with a lot of manure mixed in. They should not be transplanted as thickly, but they do prefer a somewhat thick planting. Once they're established they should be watered twice a week, and cultivate well around them the first few times.

There should be ample space between the leek rows; between each furrow be sure there's at least a full hand's breadth and they'll do well. If desired, you can plant cabbage and radishes among the leeks and they do very well. As you hoe around the leeks cover them with soil.

The seed of leeks and onions can be collected right where they're transplanted by leaving in the ground a row or two or as much as you think you may need. These will send up a scape; allow the seed to fully mature and store it well.

\section{[I6] Round onions for storage}

Round onions for storing are sown in a waning moon in the middle of January for an early harvest, but can also be sown in February and March, in well-worked soil with plenty of manure mixed in. Water them frequently and transplant them when they're grown and you see that they're ready for transplanting. To protect them from the cold and frost take the measures described above.

As soon as you see that they are ready for transplanting, in April or in May - the earlier the better - transplant them in a waning moon, although Palladius says in a new moon. Plant them as shallowly as possible so they'll develop a good round bulb, covering only the head of the onion with soil. Don't add manure when transplanting, only when sowing as indicated above. Water them after transplanting every three days and hoe around them once a week. Be sure to water them only in clear weather; they suffer if they are irrigated when it's overcast and they won't turn out so nice or develop so well.

If you want to collect seed, choose the nicest and biggest onions and plant them in the middle of November and they'll go to seed. Let them mature, then store them until it's time for sowing. Onion seeds will not sprout for thirty days after they're planted; rather, they just lay in the soil for those thirty days.

\section{[I7] Round onions}

Round onions, tender and ready for Easter time should be sown in August with radishes, and they make a good evening meal. 
[I8] Radishes

Radishes can be planted all year long but the best are those planted in March and in July. They don't need manure but the soil should be well worked and loose. Radishes planted in the month of July are the best of the whole year, but they need to be watered at times, as do those planted in March. Unless you're raising them to sell at market there's no need to reserve garden space just for radishes; they can simply be planted along the edges of the cabbage bed.

\section{[I9] Carrots}

Carrots are sown in July in a waning moon during the third quarter in deeply worked, fallow soil. They don't need manuring but water them often. They don't take transplanting, and should not be planted too thickly so they have room to expand and thrive. They will be ready by Lent. They can also be sown in the spring, but fall carrots are better. If you want a nice, fat root, you should thin away frequently some of their leaves.

[20] Turnips

Turnips are sown in July in waning moon just like carrots, and more specifically in the beginning of the month of July, since they are always better planted early than late, and the same goes for all vegetables, not just turnips: early plantings are always better than late ones. As the old saying goes "Have your turnip sowing completed, by the feast of Saints Justa and Rufina". This feast day falls on the $\mathrm{I} \mathrm{t}^{\text {th }}$ of July.

Turnips prefer well-manured, recently tilled soil. Seed should be no older than three years, because older seed just produces cabbage. To avoid sowing too thickly, mix the seed with fine soil, but wherever they come up too thickly, be sure to thin. Don't sow until the soil has been sufficiently moistened, either by rains or by watering, because they turn out better that way, and avoid shady locations. Turnips do not do well in shade, unless the soil is fertile and of exceptional quality.

Some sow turnips in plots where garlic and onions have been harvested and they do very well and are quite tasty and plump and not gnarled. Carrots are planted or sown in the same way.

\section{[2I] Parsnips}

Parsnips are sown in a waning moon in January, right after the full moon. They should be sown in cool soil mixed with well-rotted manure, and so they'll do better they should be well spaced. They can be sown any month of the year, although March parsnips, which are in the ground for the entire year, are the best and the most nutritious. If you take pieces of the parsnip root, cutting the bigger chunks into smaller pieces, and plant each piece at a depth of about two fingers' width, you'll get parsnips that way too. They prefer shady spots and cooler regions.

\section{[22] Nutsedge (tiger nut)}

Nutsedge should be sown in May and harvested in August. They should be watered whenever they need it. Also, they should be sown in good soil, for the better the soil of the seedbed, the better they'll turn out. 


\section{[23] Calabash}

Calabash are sown from the middle of January till the middle of February in a waxing moon. Make a hill of manure a good half handspan high and place the seeds on top, covering them with a little soil mixed with manure, but only a finger width deep. They need a position of full sun all day long with protection from strong winds. If cold weather is expected when they're about to sprout, cover them with cloth or rush mats so they're not so exposed to the cold. Water them every three days; the more frequent the waterings, the sooner the fruit will set, and it's even better if the water has been warmed by the sun.

Pre-soak the calabash seeds in lukewarm water if you wish, so they'll emerge sooner, within four or five days, and pre-soaked seeds should be planted as indicated above. Before soaking the seed, be sure that it's good and dry; if it's not, dry it in the sun then soak it as above. As the saying goes, "Your calabash will be great, if sown by Saint Agatha's day". This feast day is February $5{ }^{\text {th }}$. However, young calabash sets that you wish to transplant should be transplanted in the month of April in a waxing moon in full sun with plenty of manure and watered frequently. If cold or frost is expected, cover them with cloth or mats or use the protective measures we've mentioned. Plant them like this: make a hole two or three handspans wide, and one and a half handspans deep. Around the hole make a ridge of earth and then form a hill by shoveling in plenty of manure mixed with soil and then set in three young calabash plants. Do it this way so when irrigated the hole fills up with water from the trench around the hill but the water doesn't come in contact with the main stem, because this would harm the plant. Water every three days, in the afternoon when it's hot until well established. If very cold weather should come cover them.

\section{[24] Early calabash}

If you want early calabash before St. John's day in June, plant your seeds in good, well-rotted stable manure that has been sun dried and mixed with good, rich soil. Plant them on St. Valentine's day, which is the fourteenth of February, in an open sunny location and water them frequently. Once they've sprouted don't water them, but rather give them cow's milk, sheep or goat's milk, and you'll get very early calabash. If you want a slightly later harvest plant them in March, since March is the foremost month for sowing in general.

[25] Muskmelon, citron melon, watermelon, cucumber and eggplant

Cucumber, muskmelon, watermelon, citron melon and eggplant are sown from the middle of February and throughout this month in a waxing moon and with lots of manure a good half handspan high or more, as with calabash, and the seeds should be just barely covered with soil mixed with manure. They should be watered often, every three days. The spot where they're sown should get sun all day long, or most of the day. Transplant them in April and water them every three days, except for muskmelons, citron melons and watermelons, which shouldn't be watered at all once they start to mature, unless you can see that they need it. They can be direct sown so you don't need to transplant if desired. As with calabash, if the weather is cold cover them.

The seeds of muskmelons, watermelons, eggplant, cucumbers and citron melons should be soaked for two or three days in water and then sown. Citron melon, cucumber, muskmelon, watermelon and eggplant should be sown throughout the month of February. There is an interval of twenty or thirty days between these two sowings; in particular, the best time to sow citron melon, 
muskmelon and watermelon is around the feast of St. Mary of March, following the instructions given.

[26] Parsley

If you plant parsley seed in the month of March, it won’t flower until the following year.

[27] Fava beans

Fava beans are commonly planted or sown around Michaelmas. If you want an early harvest plant them in August, or in the first week of September. 


\section{Works Cited}

Agustí, Miquel. r6I7. Llibre dels secrets de agricultura, casa rustica y pastoril (Barcelona: Estampa de Esteue Liberôs) < $\underline{\text { http://links.uv.es/ClFtruf }>}$

Agustín, Miguel. I626. Libro de los secretos de agricultura, casa de campo y pastoril: traduzido de lengua catalana en castellano por Fr[ay] Miguel Agustín (Perpiñan: Luys Roure) $<\underline{\text { http://links. }}$ uv.es/leHYUog>

Banqueri, Josef Antoni (ed.). I802. Abu Ibn al-Awwam Libro de agricultura, 2 vols (Madrid: Imprenta Real) $\langle\underline{h t t p}: / /$ links.uv.es/JozAE $7 \mathrm{~N}>$

Benavent, Júlia. 2007. Biblioteca dispersa: manuscrits i incunables valencians dels segles XIV al XVII (València: Universitat de València)

BETA (Bibliografía Española de Textos Antiguos), ed. by Charles B. Faulhaber (Berkeley: The Bancroft Library, University of California, I997-) $<$ http://bancroft.berkeley.edu/philobiblon/ beta en.html> [accessed I9-I2-20I8]

BITECA (Bibliografia de Textos Antics Catalans, Valencians i Balears), ed. by Gemma Avenoza, Lourdes Soriano, and Vicenç Beltran (Berkeley: The Bancroft Library, University of California, I997-) <http://bancroft.berkeley.edu/philobiblon/biteca en.html > [accessed I9-I2-2OI8]

Burgos, Vicente de (trans.). I494. De las propriedades de las cosas. (Toulouse: H. Mayer)

Calendari dels pagesos. 20I7 (Barcelona: Publicacions Tomàs)

Capuano, Thomas M. 1987. 'Era in Berceo’s Vida de Santo Domingo de Silos 476d', Romance Notes, 27: 19I-I96

Capuano, Thomas M. (ed.). I99o. Palladius Rutilius Taurus Aemilianus Obra de agricultura traducida y comentada en 1385 por Ferrer Sayol (Madison: Hispanic Seminary of Medieval Studies)

Capuano, Thomas M. 1994. 'The agricultural Texts Appended to the Fourteenth-Century Iberian Translations of Palladius', Manuscripta: A Journal for Manuscript Research, 38.3: 253-263

Capuano, Thomas M. 1998. 'Capitols singulars deles llauors que deuras sembrar: A Late Medieval Planting Guide for the Spanish Levant', Catalan Review, I2.I: 23-35

Capuano, Thomas M. 2006. 'Una nueva versión catalana del Opus agriculturae de Palladius', Romance Philology, 59: 23I-240 <https://doi.org/IO.I484/J.RPH.2.30325I $>$

Capuano, Thomas M. 2009. 'Medieval Agricultural Lore in the Untitled Miscellany of MS 6437, Biblioteca Municipal de València (Fons Serrano Morales)', Catalan Review, 23: 9-16

Capuano, Thomas M. 20II. 'The Romance Translations of Geoffrey of Franconia’s Pelzbuch', Mediaevistik: Internationale Zeitschrift für Interdisziplinäre Mittelalterforschung, 24: 175-2I7

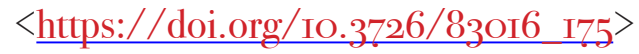

Capuano, Thomas M. (ed.). 20I3. 'Tratado de agricultura' by Ibn Wafid, Nine Technical Treatises for the Practical Professions in Spain: Transcriptions and Concordances of Representative Texts on Agriculture, Commerce, and Medicine, 1400-1777, Spanish Series I52 (New York: Hispanic Seminary of Medieval Studies)

Capuano, Thomas M. 20I4. Early Catalan Agricultural Writing and the 'Libre o regla o 
ensanyament de plantar o senbrar vinyes e arbres.. , in Sciencia.cat < $\underline{\text { http://links.uv.es/ }}$ $\underline{\mathrm{Jkd}_{4} \mathrm{Zuu}>}$

Capuano, Thomas M. 20I5. 'La Memòria de les maneres de les laurons en el corpus medieval de los scriptores rei rusticae catalanohablantes', Manuscrits: Revista d'Història Moderna, 33: 51-65 $<\underline{\text { https://doi.org/IO.5565/rev/manuscrits.69> }}$

Carril Ramos, Ángel. I988. 'Etnometeorología en Castilla y León (acercamiento a los conocimientos populares a través de la previsión del tiempo, su mundo y contexto cultural)', Revista de Dialectología y Tradiciones Populares, 43: II9-I3I

Catalogo dei manoscritti della Biblioteca Brancacciana, Biblioteca Nazionale di Napoli (Biblioteca

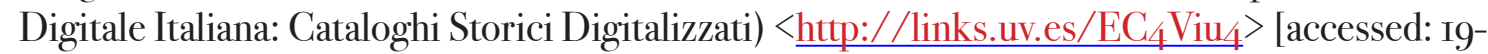
I2-20I8]

Cifuentes i Comamala, Lluís. 20OI. La ciència en català a l'edat mitjana i el Renaixement (Barcelona: Universitat de Barcelona)

Cifuentes i Comamala, Lluís. 2OI3-20I4. Els sabers útils al món rural català medieval: Agricultura, menescalia, medicina i conservació dels aliments', Études Rousillonnaises: Revue d'Histoire et Archéologie Méditerranéennes, 26: 33-50

Crescenzi, Pietro de. I538. De omnibus agriculturae partibus et de plantarum et animalium generibus (Basileae: Henricum Petrum) <http://links.uv.es/opAykD8> [accessed: IO-O4-20I9]

Dalby, Andrew (trans.). 20II. Geoponika, Farm Work: A Modern Translation of the Roman and Byzantine Farming Handbook (Devon: Prospect Books)

DCVB. 1993. Diccionari català-valencià-balear, Io vols, ed. by Antoni Maria Alcover and Francesc

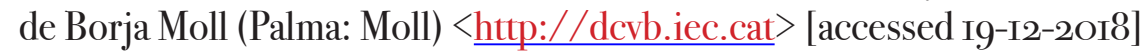

Dubler, Cesar E. (ed.). 1955. La 'Materia medica'de Dioscórides: transmisión medievaly renacentista, 6 vols (Barcelona: Emporium), III: La 'Materia medica' de Dioscórides traducida y comentada por D. Andrés de Laguna (texto crítico)

Estienne, Charles. I572. L'Agriculture et maison rustique (Paris: Iaques de Puis) < http://links.uv.es/ DhqC8nz> [accessed I9-I2-20I8]

Favà i Agud, Xavier. 200I. Diccionari dels noms de ceps i raïms: l'ampelonímia catalana (Barcelona: Institut d'Estudis Catalans)

García Sánchez, Expiración. I993-I994. 'Traducciones catalanas de textos científicos andalusíes en la Corona de Aragón', Sharq Al-Andalus IO-II: 385-40I < https://doi.org/IO.I4Ig8/ ShAnd.I993-I994.IO-II.25>

Giner Sánchez, Anna J. I989. 'Notes sobre la traducció catalana del Tractat d'agricultura de Pal-ladi feta per Ferrer Sayol', in Segon Congrés Internacional de la Llengua Catalana (Barcelona: Generalitat de Catalunya), VIII: 513-5I8

Giner, Anna J.; Trenchs, Josep. I988. 'Ferrer Sayol i el manuscrit Tractat d'agricultura de l'Arxiu Municipal de València', in Estudis sobre història de la institució notarial a Catalunya en honor de Raimon Noguera (Barcelona: Fundació Noguera), pp. I47-I53

Giralt, Emili. 2002. 'Les fonts del Llibre dels secrets de agricultura (I6I7) de fra Miquel Agusti', Mélanges offerts à Charles Leselbaum (Paris: Sorbonne, Centre d’Études Ibériques et LatinoAméricanes), pp. 327-329 
Goujaud, Émilie. 2OIO. 'Les Libres en usage à Perpignan aux XIV-XV' siècles d'après les sources notariales: Entre pluralité littéraire et linguistique', Domitia: Études et Travaux sur le Roussillon du Moyen Age à Nos Jours, II: 5-24

Harduinus, Joannes, ed. I74I. Caï Plinï Secundi Historiae Naturalis Libri XXXVII, 2 vols (Paris: Impensis Societatis) <http://links.uv.es/O5p2EKP>

Herrera, Gabriel Alonso de. I5I3. Obra de agricultura (Alcalá: Arnao Guillén de Brocar)

Hooper, Willam Davis; Ash, Harrison Boyd (trans.). 1936. Marcus Porcius Cato On Agriculture. Marcus Terentius Varro On Agriculture. (Cambridge, Mass.: Harvard University Press)

Libro de medecina llamado macer. I527. (Valladolid: Miguel de Eguía)

Llabrés, Gabriel. I895. 'Libre de agricultura segons Paladi'. Boletín de la Sociedad Arqueológica Luliana, 5-6: I5-I53

Luna-Batlle, Xavier. 20II. Libre de plantarvinyes e arbres... (Tractat d'agricultura dels. XV) (Barcelona: Publicacions de l'Abadia de Montserrat)

Luna-Batlle, Xavier. 20I3. 'El Llibre dels secrets d'agricultura, casa rústica i pastoril (1617) de Miquel Agustí: un llibre no del tot obert', Manuscrits: Revista d'Història Moderna 31: $65^{-8} 7$ (Universitat

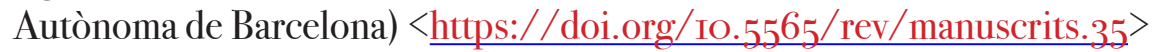

Luna-Batlle, Xavier. 20I7. 'Els Secrets d'agricultura de Miquel Agustí (I6I7): fonts i llengua', in Actes del XVIIè Col-loqui de l'AILLC, València, 2015, pp. III-I24 <https://doi. org/IO.2436/I5.8090.0I.8>

Martí Escayol, Maria Antònia. 2008. 'Les fonts del Llibre dels secrets d'agricultura de Miquel Agustí: el MS754 de la Biblioteca de Catalunya i el MS29I de la Bibliothèque Nationale de France', Afers 6o: 289-3II $\langle\underline{\text { http://links.uv.es/AIHO } 7 w d>}$

Martí Escayol, Maria Antònia. 20I2. De re rustica (Vilafranca del Penedès: Edicions i Propostes Culturals Andana)

McFadden, Lucas (ed.). 20I6. The Almanac for Farmers \& City Folk (Las Vegas: S. Doucette)

Mateu y Llopis, Felipe. 1946. Glosario hispánico de numismática (Barcelona. Consejo Superior de Investigaciones Científicas, Sección de Estudios Medievales de Barcelona)

Mensching, Guido (ed.). 1994. La sinonima delos nonbres delas medeçinas griegos e latynos e arauigos (Madrid: Arco Libros)

Meyer, Ernst (ed.). I867. Albertus Magnus De vegetabilibus libri VII(Berolini: Georgii Reimeri) <http://bibdigital.rjb.csic.es/ing/Libro.php?Libro=3900 $>$

Millás Vallicrosa, José María (ed.). 1943. 'La traducción castellana del Tratado de agricultura de Ibn Wafid', Al-Andalus 8: 28I-332

Pablo Núñez, Luis. 2007-2008. 'Ediciones e historia textual del Libro de los secretos de agricultura de Miguel Agustín’, Butlletí de la Real Acadèmia de Bones Lletres de Barcelona 5I: 199-223

Rodgers, Robert H. 1975. Palladii Rvtilii Tavri Aemiliani Viri Inlvstris Opvs agricvltvrae, De veterinaria medicina, De insitione (Leipzig: Teubner) $<$ https://doi. org/IO.I5 I5/9783IIOg66206.I $>$

Ruiz, Teófilo. 2007. Spain's Centuries of Crisis: 1300-1474 (Oxford: Blackwell)

Schiff, Mario.I9O5. La Bibliothèque du Marquis de Santillane: Étude historique et bibliographique 
de la collection de livres manuscrits de don Íñigo López de Mendoza, 1398-1458, marquès de Santillana, conde del Real de Manzanares humaniste et auteur espagnol célèbre (Paris: E. Bouillon)

Sciència.cat DB. 20I2-. Ed. by Lluís Cifuentes (Barcelona: Universitat de Barcelona) $<\underline{\text { http://www. }}$ sciencia.cat/scienciacat-db $>$ [accessed 04-O4-2OI9]

Thomas, Robert B. I799. The Farmer's Almanack: Calculated on a New and Improved Plan for the Year of our Lord, 1799 (Boston: Manning and Loring for John West)

Vallès, Joan; Veny, Joan; Vigo, Josep et al. 2OI4. Noms de plantes: Corpus de fitonímia catalana (Barcelona: Universitat Barcelona) 


\section{Appendix I: Synoptic Edition of the Seven Witnesses of the Memòria de les maneres de les llaurons}

The following chart provides a parallel transcription of the seven texts that comprise the Memòria corpus. Each is transcribed diplomatically, except that all scribal suppressions are expanded and some punctuation is added.

For ease of comparison, each chapter heading, and each conceptual unit within each chapter, is contained in its own consecutively numbered horizontal row. It should be borne in mind, however, that the witnesses differ slightly from each other in the order in which the chapters are presented; see Capuano 20I5: 6o-6r for a table demonstrating this divergence.

Folio and page indications are given at the beginning of each chapter. Note that when a cell is not introduced by a folio indication, it is understood to be a continuation of the folio side last indicated in that column. Boldface is used for rubrics and headings, even when these are not set apart from the rest of the text in the witness. Note that to economize space, not all unique material is given its own cell.

\begin{tabular}{|c|c|c|c|c|c|c|}
\hline $\begin{array}{l}M \text { (Madrid) } \\
\text { BNE IO2II }\end{array}$ & $\begin{array}{l}V \text { (Valencia) } \\
\text { BMSM 6437 }\end{array}$ & $\begin{array}{l}A \text { (Annapo- } \\
\text { lis) MS Gwara }\end{array}$ & $\begin{array}{l}P \text { (Paris) BnF } \\
\text { esp. 29I }\end{array}$ & $\begin{array}{l}B \text { (Barcelo- } \\
\text { na) BCB } 754\end{array}$ & $\begin{array}{l}N \text { (Naples) } \\
\text { Branc III AII }\end{array}$ & $\begin{array}{l}\text { Miquel } \\
\text { Agustí I6I7 }\end{array}$ \\
\hline $\begin{array}{l}\text { [fol. 2IIV3] [no } \\
\text { rubric, but the } \\
\text { text begins } \\
\text { a new para- } \\
\text { graph] }\end{array}$ & $\begin{array}{l}\text { [fol. 95r9] De } \\
\text { la ortalisa } \\
\text { quant se deu } \\
\text { sembrar }\end{array}$ & $\begin{array}{l}\text { [fol. rr] En } \\
\text { nom de deu } \\
\text { sia. Asso es } \\
\text { mamorja } \\
\text { deles maneres } \\
\text { deles laurons, } \\
\text { de plantar \& } \\
\text { de sembrar e } \\
\text { de pensar que } \\
\text { hom deu fer a } \\
\text { tota ortalissa } \\
\text { laqual } \\
\text { memorja } \\
\text { es presa } \\
\text { dels mjlors } \\
\text { ortolans de } \\
\text { barchinona } \\
\text { specialment } \\
\text { qui pensen } \\
\text { de orts quis } \\
\text { reguen. }\end{array}$ & $\begin{array}{l}\left.\text { [fol. } 5^{6 \mathrm{v}}\right] \text { Del } \\
\text { libre quint } \\
\text { Palladi. Lo } \\
\text { qual trachta } \\
\text { de sembrar } \\
\text { e plantar } \\
\text { moltes } \\
\text { maneres de } \\
\text { ortaliçes }\end{array}$ & $\begin{array}{l}\text { [IIgv6] Libre } \\
\text { quint o } \\
\text { quinta part } \\
\text { del libre en lo } \\
\text { qual se tracta } \\
\text { de sembrar } \\
\text { e plantar } \\
\text { cols e moltes } \\
\text { natures de } \\
\text { ortalices. }\end{array}$ & $\begin{array}{l}{[54 \mathrm{r}]} \\
\text { Memorial per } \\
\text { lo exercici del } \\
\text { conrear. }\end{array}$ & $\begin{array}{l}\text { [fol. } 23 r] \\
\text { Secrets pera } \\
\text { fer cols per } \\
\text { lo hiuern, } \\
\text { Pascua, y } \\
\text { temps de } \\
\text { Varemas. }\end{array}$ \\
\hline $\begin{array}{l}\text { La simjente } \\
\text { delas coles } \\
\text { verdes de } \\
\text { jnujerno }\end{array}$ & $\begin{array}{l}\text { Lauor de cols } \\
\text { verts de yuern }\end{array}$ & $\begin{array}{l}\text { E primera- } \\
\text { ment parlem } \\
\text { de cols per } \\
\text { so com mes } \\
\text { ne usam que } \\
\text { daltre. Cols } \\
\text { quj son bones } \\
\text { djuern }\end{array}$ & $\begin{array}{l}\text { e primerament } \\
\text { de cols de } \\
\text { yuern }\end{array}$ & $\begin{array}{l}\text { [5.I] }]^{153} \text { De } \\
\text { cols de Juern. } \\
\text { Primerament } \\
\text { de cols que } \\
\text { son bones } \\
\text { d'ivern }\end{array}$ & $\begin{array}{l}\text { De Cols. } \\
\text { Primerament } \\
\text { les Cols que } \\
\text { hom vol que } \\
\text { sien bones per } \\
\text { ljuern }\end{array}$ & $\begin{array}{l}\text { Si voleu } \\
\text { menjar Cols } \\
\text { en lo hiuern, }\end{array}$ \\
\hline
\end{tabular}

I53. Paragraph numbers given for BCB 754 correspond to the numbering used in the 2014 edition of this text (Capuano 20I4). 


\begin{tabular}{|c|c|c|c|c|c|c|}
\hline $\begin{array}{l}\text { M(Madrid) } \\
\text { BNE IO2II }\end{array}$ & $\begin{array}{l}\text { V(Valencia) } \\
\text { BMSM 6437 }\end{array}$ & $\begin{array}{l}\text { A (Annapo- } \\
\text { lis) MS Gwara }\end{array}$ & $\begin{array}{l}P(\text { Paris) BnF } \\
\text { esp. 29I }\end{array}$ & $\begin{array}{l}B \text { (Barcelo- } \\
\text { na) BCB } 754\end{array}$ & $\begin{array}{l}N \text { (Naples) } \\
\text { Branc III AII }\end{array}$ & $\begin{array}{l}\text { Miquel } \\
\text { Agustí I6I7 }\end{array}$ \\
\hline 3 & & $\begin{array}{l}\text { ço es que hom } \\
\text { les menja en } \\
\text { aquell temps, }\end{array}$ & & $\begin{array}{l}\text { ço es que hom } \\
\text { les menge en } \\
\text { aquell temps, }\end{array}$ & & \\
\hline $\begin{array}{l}\text { se siembran de } \\
\text { mediant junjo } \\
\text { fasta a mediant } \\
\text { julio } \\
4\end{array}$ & $\begin{array}{l}\text { se sembren de } \\
\text { mijant Juny a } \\
\text { mijant Joliol }\end{array}$ & $\begin{array}{l}\text { sembra hom } \\
\text { mjgant juny ho } \\
\text { entorn }\end{array}$ & $\begin{array}{l}\text { los quals fan } \\
\text { a sembrar } \\
\text { migant juny }\end{array}$ & $\begin{array}{l}\text { sembra les } \\
\text { hom mijant } \\
\text { juny }\end{array}$ & $\begin{array}{l}\text { sembrar les } \\
\text { mijant Juny e } \\
\text { en Juliol }\end{array}$ & $\begin{array}{l}\text { se sembran en } \\
\text { lo Iuny }\end{array}$ \\
\hline en luna vieja. & & en luna vella, & en luna vella & en la luna vella & en luna vella & $\begin{array}{l}\text { en Lluna vella, } \\
\text { apres que } \\
\text { haura fet lo } \\
\text { ple, }\end{array}$ \\
\hline 6 & & $\begin{array}{l}\text { e que agen } \\
\text { bon goret, fet } \\
\text { ab eras \& ab } \\
\text { molts fems no } \\
\text { massa empero } \\
\text { mas per } \\
\text { comjnalesa, } \\
\text { e fan a regar } \\
\text { souen, }\end{array}$ & $\begin{array}{l}\text { Equey aja } \\
\text { e stia ben } \\
\text { barbeytada } \\
\text { cauada e } \\
\text { femada la } \\
\text { terra pero } \\
\text { ab mesura lo } \\
\text { femar, ni maça } \\
\text { ni poch e fan a } \\
\text { regar soujnt }\end{array}$ & $\begin{array}{l}\text { e quey hage } \\
\text { bon guaret } \\
\text { feyt ab vores } \\
\text { e ab fems } \\
\text { covinentment, } \\
\text { no massa. E } \\
\text { fan a reguar } \\
\text { sovin }\end{array}$ & $\begin{array}{l}\text { e que hagen } \\
\text { bon goret fet } \\
\text { ab eres }\end{array}$ & $\begin{array}{l}\text { fent-los bon } \\
\text { goret, ab } \\
\text { molt fems, } \\
\text { ben podrits } \\
\text { y reposats, } \\
\text { hanse de regar } \\
\text { souint, }\end{array}$ \\
\hline $\begin{array}{l}\text { E deuen se } \\
\text { trasplantar } \\
\text { de mediante } \\
\text { agosto fasta } \\
\text { a mediante } \\
\text { setiembre } \\
7\end{array}$ & $\begin{array}{l}\text { y deuen se } \\
\text { tresplantar } \\
\text { de mijant } \\
\text { agost fins } \\
\text { a mijant } \\
\text { dehembre }\end{array}$ & $\begin{array}{l}\text { \& deu les hom } \\
\text { tresplentar } \\
\text { de migant } \\
\text { agost tro } \\
\text { migant } \\
\text { setembre }\end{array}$ & $\begin{array}{l}\text { he deuen se } \\
\text { tresplantar } \\
\text { de migant } \\
\text { agost fins } \\
\text { migant } \\
\text { setembre }\end{array}$ & $\begin{array}{l}\text { e deuen-se } \\
\text { tresplantar } \\
\text { de mijant } \\
\text { agost a mijant } \\
\text { setembre }\end{array}$ & $\begin{array}{l}\text { fan a } \\
\text { transplantar } \\
\text { de mijant } \\
\text { Agost tro } \\
\text { a mijant } \\
\text { setembre }\end{array}$ & $\begin{array}{l}\text { trasplantantlas } \\
\text { à mig Agost, } \\
\text { fins à mig } \\
\text { Setembre, }\end{array}$ \\
\hline $\begin{array}{l}\text { con mucho } \\
\text { estiercol. } \\
8\end{array}$ & ab molts fems & & & & & \\
\hline En luna vieja & en lluna vella & en luna vella, & $\begin{array}{l}\text { en luna que sia } \\
\text { vella }\end{array}$ & en la luna vella & $\begin{array}{l}\text { en luna vella } \\
\text { e no spiguen } \\
\text { ne son tan } \\
\text { longues }\end{array}$ & \\
\hline [see row 8] & [See row 8] & $\begin{array}{l}\text { \& volen } \\
\text { molts fems al } \\
\text { tresplentar } \\
\text { mes que al } \\
\text { sembrar. }\end{array}$ & $\begin{array}{l}\text { e no volen } \\
\text { masa fem } \\
\text { be que en lo } \\
\text { tresplantar ne } \\
\text { volen molt mes } \\
\text { que al sembrar }\end{array}$ & $\begin{array}{l}\text { e no volen } \\
\text { molts fems, e } \\
\text { al tresplantar } \\
\text { molt mes que } \\
\text { al sembrar }\end{array}$ & $\begin{array}{l}\text { e volen } \\
\text { molts fems al } \\
\text { transplantar } \\
\text { molt mes que } \\
\text { no al sembrar. }\end{array}$ & \\
\hline II & & & & & & $\begin{array}{l}\text { apres al } \\
\text { cap detres } \\
\text { setmanas } \\
\text { collarles ab } \\
\text { fems y terra. }\end{array}$ \\
\hline
\end{tabular}




\begin{tabular}{|c|c|c|c|c|c|c|}
\hline $\begin{array}{l}M \text { (Madrid) } \\
\text { BNE IO2II }\end{array}$ & $\begin{array}{l}V \text { (Valencia) } \\
\text { BMSM 6437 }\end{array}$ & $\begin{array}{l}A \text { (Annapo- } \\
\text { lis) MS Gwara }\end{array}$ & $\begin{array}{l}P \text { (Paris) BnF } \\
\text { esp. 29I }\end{array}$ & $\begin{array}{l}B \text { (Barcelo- } \\
\text { na) BCB } 754\end{array}$ & $\begin{array}{l}N \text { (Naples) } \\
\text { Branc III AII }\end{array}$ & $\begin{array}{l}\text { Miquel } \\
\text { Agustí I6I7 }\end{array}$ \\
\hline I2 & & & & & & $\begin{array}{l}\text { Lo tresplantar } \\
\text { tambe ha de } \\
\text { ser en Lluna } \\
\text { vella, que en la } \\
\text { noua posarian } \\
\text { molt argull, } \\
\text { y espigarian } \\
\text { prest: }\end{array}$ \\
\hline $\begin{array}{l}\text { fazen a rregar } \\
\text { I3 }\end{array}$ & y fan a regar & $\begin{array}{l}\text { Ede[u] les } \\
\text { hom regar }\end{array}$ & e regales & e reguen-se & E regales hom & $\begin{array}{l}\text { se han de } \\
\text { regar }\end{array}$ \\
\hline $\begin{array}{l}\text { de tres en tres } \\
\text { dias. fasta } \\
\text { tanto que ayan } \\
\text { tomado. }\end{array}$ & $\begin{array}{l}\text { de .iij. en .iij. } \\
\text { dies fins que } \\
\text { sien preses }\end{array}$ & $\begin{array}{l}\text { de tres en tres } \\
\text { dies tro que } \\
\text { son preses, }\end{array}$ & $\begin{array}{l}\text { dos vegades la } \\
\text { sepmana entro } \\
\text { que sien ben } \\
\text { preses }\end{array}$ & $\begin{array}{l}\text { de IIII en IIII } \\
\text { tro son ben } \\
\text { preses }\end{array}$ & $\begin{array}{l}\text { tantost com } \\
\text { son plantades } \\
\text { e despuys de } \\
\text { tres en quart } \\
\text { dies. Despuys } \\
\text { que sien } \\
\text { preses }\end{array}$ & $\begin{array}{l}\text { de [fol. 23v] } \\
\text { tres en tres } \\
\text { dias, fins sian } \\
\text { agafades, y } \\
\text { vnides ab la } \\
\text { terra, }\end{array}$ \\
\hline $\begin{array}{l}\text { E despues } \\
\text { segunt } \\
\text { que avran } \\
\text { menester. } \\
\text { I5 }\end{array}$ & $\begin{array}{l}\text { y apres segons } \\
\text { quen haura } \\
\text { mester }\end{array}$ & $\begin{array}{l}\text { e p[u]ys com } \\
\text { hom veu que } \\
\text { son preses se } \\
\text { deuen regar } \\
\text { dues uegades } \\
\text { la setmana, }\end{array}$ & & $\begin{array}{l}\text { puys fan a } \\
\text { reguar dues } \\
\text { vegades la } \\
\text { setmana }\end{array}$ & $\begin{array}{l}\text { fan a regar } \\
\text { dues voltes la } \\
\text { setmana }\end{array}$ & $\begin{array}{l}{[\text { fol. } 23 \mathrm{v}] \text { y }} \\
\text { quant veureu } \\
\text { ò hauran } \\
\text { menester. }\end{array}$ \\
\hline I6 & & $\begin{array}{l}\& \text { no les deu } \\
\text { hom massa } \\
\text { pregant metre, }\end{array}$ & $\begin{array}{l}\text { e nos deuen } \\
\text { plantar maça } \\
\text { fondes }\end{array}$ & $\begin{array}{l}\text { e nos deuen } \\
\text { metre massa } \\
\text { pregon }\end{array}$ & $\begin{array}{l}\text { No metreles } \\
\text { maça pregon }\end{array}$ & \\
\hline $\mathrm{I} 7$ & & $\begin{array}{l}\text { cor no sen fan } \\
\text { ten be, }\end{array}$ & $\begin{array}{l}\text { per que nos } \\
\text { fan tan bones }\end{array}$ & $\begin{array}{l}\text { car no sen fan } \\
\text { tant be, }\end{array}$ & $\begin{array}{l}\text { que no sen fan } \\
\text { tan be }\end{array}$ & \\
\hline I8 & & $\begin{array}{l}\text { e per ço les } \\
\text { deu hom } \\
\text { sembrar e } \\
\text { plantar en } \\
\text { luna vella, que } \\
\text { no spiguen } \\
\text { tentost com } \\
\text { farien sis } \\
\text { senbrauen } \\
\text { es plantauen } \\
\text { en luna noua } \\
\text { \& no poden } \\
\text { metre tant } \\
\text { argul de (...) } \\
\text { en alt ho en } \\
\text { lonch; }\end{array}$ & $\begin{array}{l}\text { per aso se } \\
\text { sembren en } \\
\text { luna vella he } \\
\text { sis tresplanten } \\
\text { no espigan } \\
\text { tantost com } \\
\text { farien en } \\
\text { luna noua nj } \\
\text { ergullen tant } \\
\text { en crexer en } \\
\text { alt nis fan tant } \\
\text { longues com } \\
\text { serien }\end{array}$ & $\begin{array}{l}\text { per ço se } \\
\text { sembren en } \\
\text { la luna vella. } \\
\text { si tresplanten } \\
\text { que no } \\
\text { spiguen } \\
\text { tantost como } \\
\text { ferien en la } \\
\text { luna nova, ni } \\
\text { argullen tant } \\
\text { de crexer en } \\
\text { alt, ni son tant } \\
\text { longues com } \\
\text { serien. }\end{array}$ & [see 9] & [see I2] \\
\hline
\end{tabular}




\begin{tabular}{|c|c|c|c|c|c|c|}
\hline $\begin{array}{l}M \text { (Madrid) } \\
\text { BNE IO2II }\end{array}$ & $\begin{array}{l}V \text { (Valencia) } \\
\text { BMSM 6437 }\end{array}$ & $\begin{array}{l}\text { A (Annapo- } \\
\text { lis) MS Gwara }\end{array}$ & $\begin{array}{l}P \text { (Paris) BnF } \\
\text { esp. 29I }\end{array}$ & $\begin{array}{l}B \text { (Barcelo- } \\
\text { na) BCB } 754\end{array}$ & $\begin{array}{l}N \text { (Naples) } \\
\text { Branc III AII }\end{array}$ & $\begin{array}{l}\text { Miquel } \\
\text { Agustí I6I7 }\end{array}$ \\
\hline 19 & & $\begin{array}{l}\text { e si per } \\
\text { ventura h(...) } \\
\text { qui no fos bo a } \\
\text { plantar ab les } \\
\text { altres, plan(...) } \\
\text { [fol. rv] }\end{array}$ & $\begin{array}{l}\text { E si per } \\
\text { ventura hi } \\
\text { romania } \\
\text { planter que } \\
\text { no fos bo [fol. } \\
\text { 57r] [tras?] } \\
\text { plantar ab les } \\
\text { altres plantales } \\
\text { hom avant } \\
\text { tota hora que } \\
\text { san a plantar } \\
\text { e seran bones } \\
\text { a pasqua si } \\
\text { seran tantost } \\
\text { plantades } \\
\end{array}$ & $\begin{array}{l}\text { E si per } \\
\text { ventura hi } \\
\text { romania } \\
\text { planter que } \\
\text { no fos bo ab } \\
\text { les altres, } \\
\text { plantales hom } \\
\text { avant tota } \\
\text { hora que sia a } \\
\text { plantar e seran } \\
\text { bones a Pascha } \\
\text { si seran tart } \\
\text { plantades. }\end{array}$ & & \\
\hline E sy & y si & & $\begin{array}{l}\text { e si les dites } \\
\text { cols }\end{array}$ & $\begin{array}{l}\text { E si les dites } \\
\text { cols }\end{array}$ & e si & $\begin{array}{l}\text { [fol. 23v] } \\
\text { Si quant } \\
\text { trasplantareu } \\
\text { les Cols }\end{array}$ \\
\hline $\begin{array}{l}\text { la planta es } \\
\text { en tan grant } \\
\text { quantidat } \\
\text { 2I }\end{array}$ & $\begin{array}{l}\text { lo planter es } \\
\text { molt gran }\end{array}$ & & $\begin{array}{l}\text { an la cama } \\
\text { maça larga al } \\
\text { plantar o que } \\
\text { tinguen la } \\
\text { quama torta }\end{array}$ & $\begin{array}{l}\text { han la cama } \\
\text { massa longa al } \\
\text { plantar, }\end{array}$ & $\begin{array}{l}\text { truen la cama } \\
\text { larga }\end{array}$ & $\begin{array}{l}\text { [fol. 23v] } \\
\text { tenen la cama } \\
\text { llarga, }\end{array}$ \\
\hline $\begin{array}{l}\text { deuelo } \\
\text { hombre fazer } \\
\text { yazer por el } \\
\text { surco. Asy } \\
\text { que tengan } \\
\text { las fojas de } \\
\text { aquella parte } \\
\text { por do les } \\
\text { viene el agua. } \\
22\end{array}$ & $\begin{array}{l}\text { deu lo hom } \\
\text { fer Jaure per } \\
\text { lo solch axi } \\
\text { que tinga les } \\
\text { fulles daquella } \\
\text { part hon los ve } \\
\text { laygua. }\end{array}$ & & $\begin{array}{l}\text { fes [en?] } \\
\text { manera que } \\
\text { com vinga al } \\
\text { plantar sien } \\
\text { apuntalades }\end{array}$ & $\begin{array}{l}\text { façeles hom } \\
\text { que de aquella } \\
\text { part hon deu } \\
\text { venir l'aygua } \\
\text { al regar tenga } \\
\text { lull }\end{array}$ & $\begin{array}{l}\text { feles Jaure } \\
\text { que truguen } \\
\text { lull dela part } \\
\text { hon los vendra } \\
\text { laygua. }\end{array}$ & $\begin{array}{l}\text { [fol. 23v] las } \\
\text { fareu jaure de } \\
\text { aquella part de } \\
\text { hont los ha de } \\
\text { venir la aygua } \\
\text { al regar, }\end{array}$ \\
\hline 23 & & & $\begin{array}{l}\text { e puys laygua } \\
\text { les hadresara e } \\
\text { agualara } \\
\end{array}$ & \begin{tabular}{|l} 
car vinent \\
l'aygua les \\
dreçe \\
\end{tabular} & & $\begin{array}{l}\text { [fol. 23v] y las } \\
\text { adresa. }\end{array}$ \\
\hline $\begin{array}{l}\text { Mas yo digo } \\
\text { que mas vale } \\
\text { quelas rrayzes } \\
\text { se bueluan } \\
\text { cara el agua. } \\
24\end{array}$ & $\begin{array}{l}\text { Mas yo dich } \\
\text { que mes val } \\
\text { quels giren les } \\
\text { rahels a laygua }\end{array}$ & & & & & \\
\hline $\begin{array}{l}\text { E aquestas } \\
\text { solas son } \\
\text { buenas en } \\
\text { quaresma e } \\
\text { antes de nadal. } \\
25\end{array}$ & \begin{tabular}{|l} 
y aquestes \\
son bones en \\
quaresma y \\
ans de nadal
\end{tabular} & & & & & \\
\hline
\end{tabular}




\begin{tabular}{|c|c|c|c|c|c|c|}
\hline $\begin{array}{l}\text { M(Madrid) } \\
\text { BNE Io2II }\end{array}$ & $\begin{array}{l}V \text { (Valencia) } \\
\text { BMSM 6437 }\end{array}$ & $\begin{array}{l}A \text { (Annapo- } \\
\text { lis) MS Gwara }\end{array}$ & $\begin{array}{l}\text { P(Paris) BnF } \\
\text { esp. 29I }\end{array}$ & $\begin{array}{l}B \text { (Barcelo- } \\
\text { na) BCB } 754\end{array}$ & $\begin{array}{l}N \text { (Naples) } \\
\text { Branc III AII }\end{array}$ & $\begin{array}{l}\text { Miquel } \\
\text { Agustí I6I? }\end{array}$ \\
\hline $\begin{array}{l}\text { Coles verdes } \\
\text { que son } \\
\text { buenas a } \\
\text { pasqua }\end{array}$ & $\begin{array}{l}\text { Cols verts que } \\
\text { son bones a } \\
\text { pasqua }\end{array}$ & & $\begin{array}{l}\text { De cols de } \\
\text { pasqua. Si } \\
\text { vols bones cols } \\
\text { a pasqua }\end{array}$ & $\begin{array}{l}\text { [5.2] De cols } \\
\text { de pascha. } \mathrm{Si} \\
\text { vols cols bones } \\
\text { al pascuor }\end{array}$ & & $\begin{array}{l}\text { [fol. } 23 \mathrm{v} \text {, in } \\
\text { margin: Cols } \\
\text { pera Pascua] } \\
\text { Si voleu fer } \\
\text { Cols, que sian } \\
\text { bones per } \\
\text { Pasqua, }\end{array}$ \\
\hline $\begin{array}{l}\text { se deuen } \\
\text { sembrar en } \\
\text { octubre } \\
\\
27\end{array}$ & $\begin{array}{l}\text { se deuen } \\
\text { sembrar en } \\
\text { octubre }\end{array}$ & & $\begin{array}{l}\text { sembrales en } \\
\text { la desexida } \\
\text { dagost o en } \\
\text { la exida de } \\
\text { setembre fins } \\
\text { per tot lo mes } \\
\text { de octubre e } \\
\text { de noembre }\end{array}$ & $\begin{array}{l}\text { sembra les en } \\
\text { lagost o en la } \\
\text { desexida de } \\
\text { setembre fins } \\
\text { per tot lo mes } \\
\text { de octubre e } \\
\text { de noembre, } \\
\text { quis vol }\end{array}$ & & $\begin{array}{l}\text { [fol. } 23^{\mathrm{v}} \text { ] las } \\
\text { sembrareu à la } \\
\text { fi de Setembre } \\
\text { ò per tot lo } \\
\text { Octubre }\end{array}$ \\
\hline $\begin{array}{l}\text { en luna vieja. } \\
28 \\
28\end{array}$ & enla lluna vella & & $\begin{array}{l}\text { empero en la } \\
\text { luna vella }\end{array}$ & $\begin{array}{l}\text { empero en la } \\
\text { luna vella, }\end{array}$ & & $\begin{array}{l}\text { [fol. 23v] en } \\
\text { Lluna vella à la } \\
\text { quarta haura } \\
\text { fet lo ple, }{ }^{54}\end{array}$ \\
\hline $\begin{array}{l}\text { E trasplantar } \\
\text { en Noujem- } \\
\text { bre }\end{array}$ & $\begin{array}{l}\text { e tresplantar } \\
\text { en nohembre }\end{array}$ & & $\begin{array}{l}\text { e tresplantales } \\
\text { hom tantost } \\
\text { que hom } \\
\text { conex que } \\
\text { son bones a } \\
\text { trasplantar }\end{array}$ & $\begin{array}{l}\text { e tresplant les } \\
\text { hom tantost } \\
\text { que hom } \\
\text { coneix que } \\
\text { son bones a } \\
\text { trasplantar }\end{array}$ & & $\begin{array}{l}\text { y les } \\
\text { transplantareu } \\
\text { [fol. 23v] } \\
\text { quant } \\
\text { conexereu } \\
\text { seran prou } \\
\text { grosses. }\end{array}$ \\
\hline $\begin{array}{l}\text { En luna vieja } \\
30\end{array}$ & & & & & & $\begin{array}{l}{\left[\text { fol. } 23^{v}\right]} \\
\text { Tambe en } \\
\text { Lluna vella, }\end{array}$ \\
\hline $3^{\mathrm{I}}$ & & & $\begin{array}{l}\text { ab molt fem } \\
\text { al plantar e } \\
\text { tresplantar }\end{array}$ & $\begin{array}{l}\text { ab fems al } \\
\text { plantar e al } \\
\text { tresplantar }\end{array}$ & & \\
\hline $\begin{array}{l}\text { [see row } 34 \text { ] } \\
3^{2}\end{array}$ & [see row 34] & & & $\begin{array}{l}\text { axi com havem } \\
\text { dit en les } \\
\text { altres. }\end{array}$ & & $\begin{array}{l}\text { [fol. 23v] lo } \\
\text { demes fareu } \\
\text { com esta dit, } \\
\text { ab les altres, }\end{array}$ \\
\hline 33 & & & $\begin{array}{l}\text { E gita del fem } \\
\text { en la rahel dela } \\
\text { col dos mostes } \\
\text { ha cascuna }\end{array}$ & & & \\
\hline
\end{tabular}

I54. Agusti I6I7 is the only witness that specifies the lunar quarter (immediately following the full moon). This is perhaps an elaboration of his own, since his horticultural theory prioritizes such precision, as demonstrated by the complex graphic "Taula pera conexer lo temps en lo qual se pot sembrar moltes maneras de llauor de herbas". (I6v-I8r). Notably, however, Agustí r626 omits the phrase specifying lunar quarter. 


\begin{tabular}{|c|c|c|c|c|c|c|}
\hline $\begin{array}{l}\text { M(Madrid) } \\
\text { BNE IO2II }\end{array}$ & $\begin{array}{l}\text { V(Valencia) } \\
\text { BMSM 6437 }\end{array}$ & $\begin{array}{l}A \text { (Annapo- } \\
\text { lis) MS Gwara }\end{array}$ & $\begin{array}{l}P(\text { Paris) BnF } \\
\text { esp. 29I }\end{array}$ & $\begin{array}{l}B \text { (Barcelo- } \\
\text { na) BCB } 754\end{array}$ & $\begin{array}{l}N \text { (Naples) } \\
\text { Branc III AII }\end{array}$ & $\begin{array}{l}\text { Miquel } \\
\text { Agustí I6I7 }\end{array}$ \\
\hline $\begin{array}{l}\text { fazen a rregar } \\
\text { segunt que de } \\
\text { suso avemos } \\
\text { dicho } \\
34\end{array}$ & $\begin{array}{l}\text { y fan a regar } \\
\text { segons que } \\
\text { damunt hauem } \\
\text { dit }\end{array}$ & & $\begin{array}{l}\text { E axi fan a } \\
\text { regar }\end{array}$ & $\begin{array}{l}\text { E axj fan } \\
\text { arreguar }\end{array}$ & & \\
\hline $\begin{array}{l}\text { Esy } \\
\text { brotonaran } \\
\text { fazen a } \\
\text { descabes-çar. }\end{array}$ & & & $\begin{array}{l}\text { e a tresplantar } \\
\text { mes espeses } \\
\text { que les altres } \\
\text { per que de } \\
\text { tals nja que } \\
\text { spiguen les } \\
\text { quals fan a } \\
\text { regar primeres } \\
\text { quant hom les } \\
\text { veu espigar }\end{array}$ & $\begin{array}{l}\text { mas aquestes } \\
\text { fan a plantar } \\
\text { spesses per } \\
\text { ço com de } \\
\text { tals nj ha } \\
\text { que spiguen } \\
\text { Les quals } \\
\text { fan areguar } \\
\text { primes [sic] } \\
\text { com hom les } \\
\text { veu spiguar }\end{array}$ & & $\begin{array}{l}\text { [fol. 23v] } \\
\text { acceptat, que } \\
\text { aquestes se } \\
\text { volen trans- } \\
\text { plantar mes } \\
\text { espeses, per } \\
\text { lo que ni ha } \\
\text { algu-nes que } \\
\text { espigan, les } \\
\text { quals fan } \\
\text { arrencar, } \\
\text { quant veureu } \\
\text { espigan, antes } \\
\text { ques perdian. }\end{array}$ \\
\hline $\begin{array}{l}\text { Simjente de } \\
\text { Coles verdes } \\
\text { que son } \\
\text { buenas en } \\
\text { setiembre o } \\
\text { en octubre se } \\
\text { deuen sembrar } \\
\text { en febrero o } \\
\text { en março. E } \\
\text { trasplantar } \\
\text { en abril o en } \\
\text { mayo en luna } \\
\text { vieja. E seran } \\
\text { buenas en } \\
\text { vendimjas. }\end{array}$ & $\begin{array}{l}\text { llauor de cols } \\
\text { verts que } \\
\text { son bones en } \\
\text { setembre o } \\
\text { en octubre se } \\
\text { deuen sembrar } \\
\text { en febrer o } \\
\text { en març y } \\
\text { tresplantar en } \\
\text { abril o en maig } \\
\text { en lluna vella y } \\
\text { seran bones en } \\
\text { vene-mes. }{ }^{55}\end{array}$ & & $\begin{array}{l}\text { De cols per } \\
\text { lo estiu. En } \\
\text { fer bones } \\
\text { cols destiu se } \\
\text { volen sembrar } \\
\text { migant març } \\
\text { en la luna vella } \\
\text { e tresplantales } \\
\text { en luna vella } \\
\text { e volen molt } \\
\text { fem al sembrar } \\
\text { e molt mes al } \\
\text { tresplantar } \\
\text { e fan a regar } \\
\text { axj com dich } \\
\text { amunt. }\end{array}$ & $\begin{array}{l}\text { [fol. I2Or] } \\
\text { [5·3] De cols } \\
\text { de Stiu. Cols } \\
\text { destiu que } \\
\text { son bones } \\
\text { en veremes e } \\
\text { al Setembre } \\
\text { sembra les } \\
\text { mijant març en } \\
\text { la Luna vella e } \\
\text { tresplanta les } \\
\text { hom sempre } \\
\text { que son bones } \\
\text { de tresplantar } \\
\text { en Luna } \\
\text { vella e volen } \\
\text { molt fems al } \\
\text { sembrar Mas } \\
\text { al tresplantar } \\
\text { ne valen molt } \\
\text { mes axi com es } \\
\text { dit deles altres } \\
\text { axj mateix del } \\
\text { reguar }\end{array}$ & $\begin{array}{l}\text { Cols per a } \\
\text { veremes. } \\
\text { Si vols } \\
\text { cols perles } \\
\text { venemes } \\
\text { sembreles } \\
\text { mijant ffebrer } \\
\text { tro mijant } \\
\text { Mars en la } \\
\text { luna vella ab } \\
\text { fems axicom } \\
\text { dessus es dit. e } \\
\text { transplantales } \\
\text { com seran } \\
\text { sofficients en } \\
\text { luna vella. }\end{array}$ & $\begin{array}{l}\text { [fol. 23v, in } \\
\text { margin: Cols } \\
\text { per lo temps } \\
\text { de varemas] } \\
\text { Si voleu fer } \\
\text { Cols que } \\
\text { seran bones } \\
\text { en temps de } \\
\text { varemas, les } \\
\text { sembrareu de } \\
\text { mig Fabrer, } \\
\text { fins à mig } \\
\text { Mars, en Lluna } \\
\text { vella, com } \\
\text { esta dit de les } \\
\text { altres, y las } \\
\text { transplantareu } \\
\text { quant } \\
\text { conexereu } \\
\text { seran } \\
\text { bones pera } \\
\text { transplantar, } \\
\text { tambe ab } \\
\text { Lluna vella } \\
\text { ab fems, al } \\
\text { sembrar y } \\
\text { trasplantar, } \\
\text { regantles com } \\
\text { esta dalt dit } \\
\text { de las altras. } \\
\text { (...) })^{156}\end{array}$ \\
\hline
\end{tabular}




\begin{tabular}{|c|c|c|c|c|c|c|}
\hline $\begin{array}{l}\text { M(Madrid) } \\
\text { BNE IO2II }\end{array}$ & $\begin{array}{l}\text { V(Valencia) } \\
\text { BMSM 6437 }\end{array}$ & $\begin{array}{l}A \text { (Annapo- } \\
\text { lis) MS Gwara }\end{array}$ & $\begin{array}{l}P(\text { Paris) BnF } \\
\text { esp. 29I }\end{array}$ & $\begin{array}{l}B \text { (Barcelo- } \\
\text { na) BCB } 754\end{array}$ & $\begin{array}{l}N \text { (Naples) } \\
\text { Branc III AII }\end{array}$ & $\begin{array}{l}\text { Miquel } \\
\text { Agustí I6I7 }\end{array}$ \\
\hline 37 & & & $\begin{array}{l}\text { [fol. 57v] De } \\
\text { cols deSicilia. } \\
\text { Si vols plantar } \\
\text { cols de Seçjlia } \\
\text { sembrales } \\
\text { ha .viiij. dies } \\
\text { abans o apres } \\
\text { de sent Johan } \\
\text { de juny. E } \\
\text { tenjrlas a prop } \\
\text { de regar. E } \\
\text { tresplantales } \\
\text { quant seran } \\
\text { hun poch } \\
\text { crescudes. E } \\
\text { fes quey fira lo } \\
\text { sol tot lo dia. }\end{array}$ & $\begin{array}{l}\text { [5.4] De Cols } \\
\text { de Sicilia. Si } \\
\text { vols fer planter } \\
\text { de cols de } \\
\text { Sicilia sembra } \\
\text { les a .viij. dies } \\
\text { ans o apres } \\
\text { de Sant Johan } \\
\text { de Juny e ti } \\
\text { les a prop de } \\
\text { reguar e com } \\
\text { sien grans } \\
\text { tresplanta les } \\
\text { e guarda quey } \\
\text { fira lo sol. }\end{array}$ & & \\
\hline $3^{8}$ & & & $\begin{array}{l}\text { De cols de } \\
\text { capdell. }{ }^{57}\end{array}$ & & & \\
\hline $\begin{array}{l}\text { Spinacas, } \\
\text { Armuelles, } \\
\text { bledas, \& } \\
\text { bretons }\end{array}$ & $\begin{array}{l}\text { Spinax blets y } \\
\text { bledes }\end{array}$ & & $\begin{array}{l}\text { [fol. } 5^{8 r} \text { De } \\
\text { arbolam } \\
\text { de Pasqua. } \\
\text { Erbolam } \\
\text { de Pasqua } \\
\text { se enten la } \\
\text { ensalada ço } \\
\text { es morritot, } \\
\text { ruques, } \\
\text { julivert e altres } \\
\text { erbes quj son } \\
\text { bones per } \\
\text { fer ansalada } \\
\text { quant encara } \\
\text { espinachs, } \\
\text { bledes e altres } \\
\text { frasques }\end{array}$ & $\begin{array}{l}{[5 \cdot 5] \text { De }} \\
\text { erbolam } \\
\text { de pascha. } \\
\text { Arbolam lo } \\
\text { qual es bo al } \\
\text { pascuor ço } \\
\text { es spinachs } \\
\text { colills bledes e } \\
\text { almolls }\end{array}$ & & $\begin{array}{l}{[\text { fol. } 24 \mathrm{r}] \text { Per }} \\
\text { fer arbolam } \\
\text { de pastors. } \\
\text { Arbolam de } \\
\text { Pastors, y de } \\
\text { Companya, }\end{array}$ \\
\hline
\end{tabular}

I55. In Capuano (2015: 6o table) this passage from BMV 6437 "llauor de cols verts" (95r) was misconstrued as unique to this ms. In fact, it corresponds, as shown here, to the chapter on the September cabbage crop.

I56. (...) is used in this column to indicate the intervention of material in Agustís compilation taken from sources other than the Memòria.

I57. $P$ is the only witness that gives this chapter: "De cols de capdell se volen nj pus nj mes sembrar com les altres cols pero hull te mostrar en qual manera no tenint de aquella sement en qual forma ne poras fer prodoyr. Primerament tu cauaras hun troç de terra tanta com deles dites cols volras plantar o sembrar e aquella faras molt be femar e quant vinga ala festa de Santa Justa e Rufina quj es ha .xvij. de juljol sembraras aquella terra de sement de naps molt espesa tam que los huns estigen mesclats ab los altres e regals dos o tres vegades empero guardar en lo sembrar que la terra estiga de saho e nols culles e com vendra en la luna plena de febrer com vna exada tallant escabesaras tots aquells naps e sembra sements de cols de qual se hulla natura e puys sia cuberta aquella sement de terra [e] fem ben podrit hun dit en groç e regales en coujnent e despuys hun dia pert [sic] altre ruxales ab algun vexell en aso bo fins atant que sien exides. [fol. $5^{8 r}$ ] E despuys donals aygua de dos en dos dies e quant seran granetes tresplantales e seran cols copades e

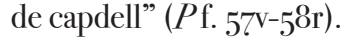




\begin{tabular}{|c|c|c|c|c|c|c|}
\hline $\begin{array}{l}\text { M(Madrid) } \\
\text { BNE IO2II }\end{array}$ & $\begin{array}{l}V \text { (Valencia) } \\
\text { BMSM 6437 }\end{array}$ & $\begin{array}{l}A \text { (Annapo- } \\
\text { lis) MS Gwara }\end{array}$ & $\begin{array}{l}P \text { (Paris) BnF } \\
\text { esp. 29I }\end{array}$ & $\begin{array}{l}B \text { (Barcelo- } \\
\text { na) BCB } 754\end{array}$ & $\begin{array}{l}N \text { (Naples) } \\
\text { Branc III AII }\end{array}$ & $\begin{array}{l}\text { Miquel } \\
\text { Agustí I6I? }\end{array}$ \\
\hline $\begin{array}{l}\text { siembra } \\
\text { hombre en } \\
\text { enero \& en } \\
\text { março E en } \\
\text { abril [fol. 2I2r] } \\
\text { en qual se } \\
\text { quiera luna E } \\
\text { non qujeren } \\
\text { mucho } \\
\text { estiercol si } \\
\text { non agua E } \\
\text { non se quieren } \\
\text { trasplan-tar. } \\
\text { 40 }\end{array}$ & $\begin{array}{l}\text { sembra hom } \\
\text { en giner y } \\
\text { en març y en } \\
\text { abril en qual } \\
\text { seuol lluna y } \\
\text { no volen molts } \\
\text { fems mas } \\
\text { volen aygua } \\
\text { y nos volen } \\
\text { tresplantar }\end{array}$ & & $\begin{array}{l}\text { sembre hom } \\
\text { a la entrada } \\
\text { de jener e noy } \\
\text { guarda hom } \\
\text { luna que noy } \\
\text { cal e volen } \\
\text { molt fem e } \\
\text { regar souent } \\
\text { e no les cal } \\
\text { tresplantar. }\end{array}$ & $\begin{array}{l}\text { sembra hom } \\
\text { en la entrada } \\
\text { de Giner E noy } \\
\text { guarda luna } \\
\text { quj nos vol e } \\
\text { volen molts } \\
\text { fems e reguar } \\
\text { souint e nos } \\
\text { tresplanten }\end{array}$ & & $\begin{array}{l}\text { fareu en la } \\
\text { entrada del } \\
\text { mes de Ianer, } \\
\text { en qualseuol } \\
\text { Lluna, de gra } \\
\text { de Espinachs, } \\
\text { y de Colets } \\
\text { tot mesclat, } \\
\text { femantlas } \\
\text { molt, y regar } \\
\text { souint, sens } \\
\text { trasplan- } \\
\text { tarles. }\end{array}$ \\
\hline \multicolumn{7}{|l|}{$\begin{array}{l}\text { Las espinacas } \\
\text { solas quieren } \\
\text { mucho } \\
\text { estiercol. } \\
\text { 4I }\end{array}$} \\
\hline [see row 40] & [see row 40] & & $\begin{array}{l}\text { De erbolam } \\
\text { encara. } \\
\text { Sembra } \\
\text { enquara hom } \\
\text { erbolam } \\
\text { migant març } \\
\text { ab molt fem e } \\
\text { no si guarda } \\
\text { luna. }\end{array}$ & $\begin{array}{l}\text { [5.6] } \\
\text { Erbolam. } \\
\text { Erbolam } \\
\text { sembre hom } \\
\text { per semblant } \\
\text { mijant Marc } \\
\text { ab molts fems } \\
\text { e no si guorda } \\
\text { Luna njs } \\
\text { tresplanten }\end{array}$ & & $\begin{array}{l}\text { Altre Arbolam } \\
\text { podreu fer, y } \\
\text { sembrar, a mig } \\
\text { mes de Mars, } \\
\text { sens guardar } \\
\text { Lluna, ab molt } \\
\text { fems, y regar } \\
\text { souint. }\end{array}$ \\
\hline [see row 40] & [see row 40] & & & \begin{tabular}{|l|} 
[5.7] De \\
erbolam. \\
Erbolam ço es \\
blets e bledes \\
spinachs e \\
alguns grans \\
sembra hom \\
ala entrada \\
de Abril es \\
fan afemar e \\
arreguar e nols \\
cal tresplantar \\
nj guardar \\
Luna
\end{tabular} & & $\begin{array}{l}\text { Tambe podreu } \\
\text { fer altre } \\
\text { Arbolam, } \\
\text { prenent grans } \\
\text { de Blets, y } \\
\text { de Bledas, ab } \\
\text { alguns grans } \\
\text { de Espinachs, } \\
\text { tot a la mescla, } \\
\text { los sembrareu } \\
\text { en la entrada } \\
\text { del mes de } \\
\text { Abril, los } \\
\text { famareu y } \\
\text { regareu com } \\
\text { laltre, y nols } \\
\text { trasplantareu, } \\
\text { ni aguardareu } \\
\text { Lluna. }\end{array}$ \\
\hline
\end{tabular}




\begin{tabular}{|c|c|c|c|c|c|c|}
\hline $\begin{array}{l}\text { M(Madrid) } \\
\text { BNE IO2II }\end{array}$ & $\begin{array}{l}V \text { (Valencia) } \\
\text { BMSM 6437 }\end{array}$ & $\begin{array}{l}A \text { (Annapo- } \\
\text { lis) MS Gwara }\end{array}$ & $\begin{array}{l}P(\text { Paris) BnF } \\
\text { esp. 29I }\end{array}$ & $\begin{array}{l}B \text { (Barcelo- } \\
\text { na) BCB } 754\end{array}$ & $\begin{array}{l}N \text { (Naples) } \\
\text { Branc III AII }\end{array}$ & $\begin{array}{l}\text { Miquel } \\
\text { Agustí I6I7 }\end{array}$ \\
\hline 44 & & & $\begin{array}{l}\text { daquj auant } \\
\text { fins ha migant } \\
\text { agost no } \\
\text { sembra hom } \\
\text { espinachs } \\
\text { bledes e blets } \\
\text { verts } \\
\end{array}$ & $\begin{array}{l}\text { e daquiauant } \\
\text { no sembra hom } \\
\text { spinachs mijant } \\
\text { Agost [sic] }\end{array}$ & & \\
\hline 45 & & & $\begin{array}{l}\text { De spinachs } \\
\text { Spinachs menja } \\
\text { hom en lavent } \\
\text { de Nadal. }\end{array}$ & $\begin{array}{l}\text { [5.8] De } \\
\text { spinachs. }\end{array}$ & & $\begin{array}{l}\text { [fol. } 24 \mathrm{r}] \text { Per } \\
\text { fer espinachs } \\
\text { qve seran bons } \\
\text { en lo Iuerny } \\
\text { Quaresma. } \\
\text { Si voleu fer } \\
\text { Espinachs que } \\
\text { seran bons } \\
\text { en lo Iuern y } \\
\text { Quaresma, }\end{array}$ \\
\hline 46 & & & \begin{tabular}{|l|} 
E haquets se \\
volen sembrar \\
en la vella \\
luna de agost \\
migant aquell \\
mes ab molt \\
fem. E fan a \\
regar a vegades \\
axj como [sic] \\
conexeras ho \\
auran mester. \\
\end{tabular} & $\begin{array}{l}\text { Spinachs } \\
\text { sembre hom } \\
\text { mijant Agost } \\
\text { ab la Luna vella } \\
\text { ab molts fems } \\
\text { e fan areguar } \\
\text { auagades com } \\
\text { hom coneix } \\
\text { que o han ops }\end{array}$ & & $\begin{array}{l}\text { los sembrareu } \\
\text { en lo mes } \\
\text { de Agost en } \\
\text { Lluna vella, } \\
\text { ab molt fems, } \\
\text { y fan a regar } \\
\text { quant veureu } \\
\text { ho auran } \\
\text { menester, }\end{array}$ \\
\hline 47 & & & & $\begin{array}{l}\text { e aquests } \\
\text { spinachs } \\
\text { son bons de } \\
\text { Juern [e] en } \\
\text { quaresma }\end{array}$ & & $\begin{array}{l}\text { y axi seran } \\
\text { bons de Iuern y } \\
\text { Quaresma. }\end{array}$ \\
\hline $\begin{array}{l}\text { Spinacas se } \\
\text { siembran } \\
\text { de mediant } \\
\text { setiembre } \\
\text { fasta a mediant } \\
\text { octubre. E } \\
\text { avn fasta en } \\
\text { noujembre } \\
\text { en luna vieja } \\
\text { con mucho } \\
\text { estiercol \& a } \\
\text { menudo rregar } \\
\text { son mucho } \\
\text { buenas en la } \\
\text { quaresma. }\end{array}$ & $\begin{array}{l}\text { Spinax se } \\
\text { sembren } \\
\text { de mijant } \\
\text { setembre } \\
\text { fins a mijant } \\
\text { octubre } \\
\text { encara fins en } \\
\text { nohembre en } \\
\text { lluna vella ab } \\
\text { molts fems y } \\
\text { souint regar }\end{array}$ & & $\begin{array}{l}{\left[\text { fol. } 5^{8 \mathrm{v}]} \text { De }\right.} \\
\text { spinachs } \\
\text { encara. } \\
\text { Encara en altra } \\
\text { manera se } \\
\text { volen sembrar } \\
\text { migant } \\
\text { setembre en } \\
\text { luna vella. } \\
\text { E regals axj } \\
\text { como han } \\
\text { mester. E } \\
\text { sembra los } \\
\text { hom ab molt } \\
\text { fem. E son } \\
\text { bons en la } \\
\text { quaresma }\end{array}$ & $\begin{array}{l}\text { [5.9] De } \\
\text { spinachs. } \\
\text { Encara altres } \\
\text { spinachs } \\
\text { sembra } \\
\text { hom mijant } \\
\text { Setembre } \\
\text { tro mijant } \\
\text { Octubre en } \\
\text { la Luna vella } \\
\text { e reguals } \\
\text { hom com ho } \\
\text { han mester e } \\
\text { sembrals hom } \\
\text { ab molts fems } \\
\text { e son bons de } \\
\text { tota quaresma } \\
\text { si es alta o } \\
\text { baxa }\end{array}$ & & $\begin{array}{l}\text { Altres } \\
\text { Espinachs } \\
\text { podreu fer per } \\
\text { la Quaresma, } \\
\text { o sia alta, o } \\
\text { baxa, si los } \\
\text { sembrau a } \\
\text { mig mes de } \\
\text { Setembra, } \\
\text { fins en mig de } \\
\text { Octubre, en } \\
\text { Lluna vella, ab } \\
\text { molt fems, y } \\
\text { regarlos com } \\
\text { los altres, }\end{array}$ \\
\hline
\end{tabular}




\begin{tabular}{|c|c|c|c|c|c|c|}
\hline $\begin{array}{l}\text { M(Madrid) } \\
\text { BNE IO2II }\end{array}$ & $\begin{array}{l}\text { V(Valencia) } \\
\text { BMSM 6437 }\end{array}$ & $\begin{array}{l}A \text { (Annapo- } \\
\text { lis) MS Gwara }\end{array}$ & $\begin{array}{l}P(\text { Paris) BnF } \\
\text { esp. 29I }\end{array}$ & $\begin{array}{l}B \text { (Barcelo- } \\
\text { na) BCB } 754\end{array}$ & $\begin{array}{l}N \text { (Naples) } \\
\text { Branc III AII }\end{array}$ & $\begin{array}{l}\text { Miquel } \\
\text { Agustí I6I? }\end{array}$ \\
\hline 49 & & & $\begin{array}{l}\text { De espinachs } \\
\text { encara. } \\
\text { Alguns } \\
\text { hortolans } \\
\text { dien que la } \\
\text { sement vella es } \\
\text { mjllor que la } \\
\text { del any. E fan } \\
\text { ho en aquesta } \\
\text { manera, que } \\
\text { meten la } \\
\text { sement en } \\
\text { hun cabaç e } \\
\text { puys cusen } \\
\text { lo cabas. E } \\
\text { puys ab huna } \\
\text { corda a calenlo } \\
\text { en hun pou } \\
\text { dins laygua } \\
\text { e lexenloy } \\
\text { estar sis o set } \\
\text { dies. E apres } \\
\text { traenlo de } \\
\text { aquell cabaç } \\
\text { e metlo en } \\
\text { altre e tornel } \\
\text { a metre en lo } \\
\text { pou per espay } \\
\text { de .iij. o .iiij. } \\
\text { jorns encara } \\
\text {.v. e la hora la } \\
\text { sement grilla. } \\
\text { E llauors } \\
\text { sembra la hom } \\
\text { ab molt fem e } \\
\text { ixen tantost. }\end{array}$ & $\begin{array}{l}\text { [5.Io] De } \\
\text { spinachs } \\
\text { Alguns } \\
\text { ortolans diuen } \\
\text { quela lauor } \\
\text { vella es millor } \\
\text { que la del any } \\
\text { mateix e fan } \\
\text { axi meten } \\
\text { la lauor en } \\
\text { huna senalla } \\
\text { e cusen la e } \\
\text { puys meten la } \\
\text { en hun pou en } \\
\text { laygua e lexen } \\
\text { star vj. o vij. } \\
\text { jorns en apres } \\
\text { descusen la } \\
\text { e meten la } \\
\text { lauor dins en } \\
\text { la senalla puys } \\
\text { tornen cosir } \\
\text { la senalla e } \\
\text { meten la en lo } \\
\text { pou en guisa } \\
\text { que no toch } \\
\text { en laygua e } \\
\text { stiguey.iiij. } \\
\text { o v. jorns e } \\
\text { lauors la lauor } \\
\text { es grillada e } \\
\text { sembra la hom } \\
\text { ab molts fems }\end{array}$ & & $\begin{array}{l}\text { y se fan millors } \\
\text { de sement } \\
\text { vella. (...) }\end{array}$ \\
\hline
\end{tabular}




\begin{tabular}{|c|c|c|c|c|c|c|}
\hline $\begin{array}{l}\text { M(Madrid) } \\
\text { BNE IO2II }\end{array}$ & $\begin{array}{l}\text { V(Valencia) } \\
\text { BMSM 6437 }\end{array}$ & $\begin{array}{l}A \text { (Annapo- } \\
\text { lis) MS Gwara }\end{array}$ & $\begin{array}{l}P(\text { Paris) BnF } \\
\text { esp. 29I }\end{array}$ & $\begin{array}{l}B \text { (Barcelo- } \\
\text { na) BCB } 754\end{array}$ & $\begin{array}{l}N \text { (Naples) } \\
\text { Branc III AII }\end{array}$ & $\begin{array}{l}\text { Miquel } \\
\text { Agustí I6I7 }\end{array}$ \\
\hline $\begin{array}{l}\text { Lechugas } \\
\text { tempranas } \\
\text { se siembran } \\
\text { enla luna vieja } \\
\text { de mediant } \\
\text { setiembre } \\
\text { fasta mediado } \\
\text { de octubre E } \\
\text { fazen a rregar } \\
\text { quando lo han } \\
\text { menester E } \\
\text { trasplantan se } \\
\text { antes de nadal } \\
\text { con estiercol. } \\
\text { E fazen a } \\
\text { rregar. }\end{array}$ & $\begin{array}{l}\text { Letugues } \\
\text { primerenques } \\
\text { se sembren } \\
\text { en la lluna } \\
\text { vella de mijant } \\
\text { setembre } \\
\text { fins mijant } \\
\text { octubre y fan } \\
\text { a tresplantar } \\
\text { ans de nedal } \\
\text { ab fems y fan a } \\
\text { regar }\end{array}$ & & $\begin{array}{l}\text { De letugues } \\
\text { Letugues } \\
\text { primerenques } \\
\text { sembra hom } \\
\text { migant hagost } \\
\text { o de setembre } \\
\text { entro migant } \\
\text { ochtubre en } \\
\text { luna vella ab } \\
\text { molt fem. E } \\
\text { fan a regar axj } \\
\text { com veuras } \\
\text { auran mester. } \\
\text { E tresplantales } \\
\text { en la auent de } \\
\text { nadal ab molt } \\
\text { fem en luna } \\
\text { vella e regar } \\
\text { les has de.viii. } \\
\text { en nou dies } \\
\text { per amor deles } \\
\text { jelades. }\end{array}$ & $\begin{array}{l}\text { [5.II] De } \\
\text { Letugues. } \\
\text { Les letugues } \\
\text { primarenques } \\
\text { sembra } \\
\text { hom mijant } \\
\text { Setembre } \\
\text { tro mijant } \\
\text { Octubre en la } \\
\text { Luna vella ab } \\
\text { molt fems e } \\
\text { fan aregar com } \\
\text { ops ho han e } \\
\text { tresplanta les } \\
\text { hom en lauent } \\
\text { de Nadal ab } \\
\text { fems en la luna } \\
\text { [blank space] } \\
\text { e regua les } \\
\text { hom com ops } \\
\text { o han }\end{array}$ & $\begin{array}{l}\text { [54v] } \\
\text { Lentugues } \\
{[\text { sic]. }} \\
\text { Letugues } \\
\text { primerenques } \\
\text { sembre } \\
\text { hom mijant } \\
\text { setembre tro a } \\
\text { mijant } \\
\text { Octubre en } \\
\text { luna vella } \\
\text { ab molts } \\
\text { fems e fan a } \\
\text { regar com } \\
\text { veu hom que } \\
\text { obs ho han e } \\
\text { transplantales } \\
\text { hom en lauent } \\
\text { en luna vella } \\
\text { ab fems. }\end{array}$ & $\begin{array}{l}\text { [fol. } 24 \text { r] } \\
\text { Secrets per } \\
\text { fer lletvgues } \\
\text { de moltes } \\
\text { maneras. } \\
\text { Lletvgves } \\
\text { primarencas, } \\
\text { y mes } \\
\text { derrarencas, } \\
\text { fareu si les } \\
\text { sembrau de } \\
\text { mig Setembra, } \\
\text { fins en mig } \\
\text { mes de } \\
\text { Octubre en } \\
\text { Lluna vella, } \\
\text { ab molt fems, } \\
\text { y regarles } \\
\text { sempra } \\
\text { ho auran } \\
\text { menester, y } \\
\text { trasplantarles } \\
\text { en lo Aduent, } \\
\text { en la Lluna } \\
\text { vella, ab } \\
\text { molt fems, } \\
\text { regantlas com } \\
\text { esta dit. }\end{array}$ \\
\hline $\begin{array}{l}\text { E semejante } \\
\text { mente puede } \\
\text { hombre } \\
\text { sembrar en } \\
\text { Noujembre o } \\
\text { en deziembre. }\end{array}$ & $\begin{array}{l}\text { per semblant } \\
\text { ne pot hom } \\
\text { sembrar en } \\
\text { nohembre y en } \\
\text { dehembre }\end{array}$ & & $\begin{array}{l}\text { [fol. 59r] De } \\
\text { lletugues } \\
\text { enquara. } \\
\text { Alguns } \\
\text { sembren } \\
\text { letuges en } \\
\text { lo mes de } \\
\text { noembre } \\
\text { entro mjgant } \\
\text { dehembre e } \\
\text { tresplantales } \\
\text { en jener. Al } \\
\text { sembrar e al } \\
\text { collir per a } \\
\text { tresplantar } \\
\text { guarda hom la } \\
\text { luna vella per } \\
\text { que ne son } \\
\text { pus saboroses. } \\
\text { E met hi } \\
\text { hom molt } \\
\text { fem. E sien } \\
\text { regades axj } \\
\text { com ho auran } \\
\text { mester.158 }\end{array}$ & $\begin{array}{l}\text { [5.I2] De } \\
\text { letugues. } \\
\text { Algunes } \\
\text { letuges } \\
\text { sembra hom } \\
\text { de Noembre } \\
\text { tro amijant } \\
\text { deembre e } \\
\text { tresplanta les } \\
\text { hom de Giner } \\
\text { al sembrar e al } \\
\text { tresplantar en } \\
\text { la Luna vella } \\
\text { ab molt fems } \\
\text { reguant quant } \\
\text { ops o han }\end{array}$ & $\begin{array}{l}{[54 \mathrm{v}]} \\
\text { Letugues. } \\
\text { Letugues } \\
\text { per lestiu } \\
\text { sembre hom } \\
\text { en noembre } \\
\text { tro a mijant } \\
\text { deembre e } \\
\text { traspantales } \\
\text { [sic] hom en } \\
\text { Janer ab molts } \\
\text { fems. Regales } \\
\text { hom com hom } \\
\text { coneix ho } \\
\text { hagen ops. }{ }^{159}\end{array}$ & $\begin{array}{l}\text { Altres } \\
\text { Lletugues mes } \\
\text { derrarencas } \\
\text { haureu, si las } \\
\text { sembrau de } \\
\text { Noembra, } \\
\text { fins en mig } \\
\text { Desembra, } \\
\text { y les } \\
\text { trasplantareu } \\
\text { de Ianer, o de } \\
\text { Fabrer, tot en } \\
\text { Lluna vella, ab } \\
\text { molt fems, y } \\
\text { regar com esta } \\
\text { dit. (.... })^{\text {r6o }}\end{array}$ \\
\hline
\end{tabular}




\begin{tabular}{|c|c|c|c|c|c|c|}
\hline $\begin{array}{l}\text { M(Madrid) } \\
\text { BNE IO2II }\end{array}$ & $\begin{array}{l}\text { V(Valencia) } \\
\text { BMSM 6437 }\end{array}$ & $\begin{array}{l}\text { A (Annapo- } \\
\text { lis) MS Gwara }\end{array}$ & $\begin{array}{l}P(\text { Paris }) \mathrm{BnF} \\
\text { esp. 29I }\end{array}$ & $\begin{array}{l}B \text { (Barcelo- } \\
\text { na) BCB } 754\end{array}$ & $\begin{array}{l}N \text { (Naples) } \\
\text { Branc III AII }\end{array}$ & $\begin{array}{l}\text { Miquel } \\
\text { Agustí I6I7 }\end{array}$ \\
\hline $\begin{array}{l}\text { Ajos se } \\
\text { plantan en } \\
\text { luna vieja. E } \\
\text { en Noujembre } \\
\text { menos de } \\
\text { estiercol bien } \\
\text { cauada la } \\
\text { tierra }\end{array}$ & $\begin{array}{l}\text { Alls se planten } \\
\text { en lluna vella } \\
\text { en nohembre } \\
\text { sens fems } \\
\text { en terra ben } \\
\text { cauada }\end{array}$ & & $\begin{array}{l}\text { [fol. 59v] De } \\
\text { plantar alls. } \\
\text { [fol. 6or] } \\
\text { Alls planta } \\
\text { hom migant } \\
\text { deembre en } \\
\text { luna vella } \\
\text { en terra ben } \\
\text { cauada e ben } \\
\text { barbeytada e } \\
\text { menys de fem. }\end{array}$ & $\begin{array}{l}\text { [5.r3] De alls. } \\
\text { Alls planta } \\
\text { hom mijant } \\
\text { dehembre } \\
\text { en la Luna } \\
\text { vella en terra } \\
\text { ben cauada } \\
\text { e guaretada } \\
\text { menys de fems }\end{array}$ & $\begin{array}{l}\text { [54v] Ayls. } \\
\text { Ayls planta } \\
\text { hom mijant } \\
\text { Noembre en } \\
\text { luna vella e } \\
\text { volen terra } \\
\text { ben cauada e } \\
\text { goretada sens } \\
\text { fems. }\end{array}$ & $\begin{array}{l}\text { [fol. 27v] De } \\
\text { secrets dels } \\
\text { alls. Alls } \\
\text { se han de } \\
\text { sembrar à mig } \\
\text { Nouembra, } \\
\text { en la Lluna } \\
\text { vella, volen } \\
\text { terra seca, no } \\
\text { humida, ni } \\
\text { molt grassa, }\end{array}$ \\
\hline 53 & & & $\begin{array}{l}\text { E fan a plantar } \\
\text { en loch de } \\
\text { regadiu en } \\
\text { manera ques } \\
\text { pugen regar } \\
\text { de .viiij. en } \\
\text { viiij. dies }\end{array}$ & $\begin{array}{l}\text { e fan areguar } \\
\text { en loch de } \\
\text { reguiu de viij. } \\
\text { en viij. jorns }\end{array}$ & $\begin{array}{l}\text { fan a regar de } \\
\text {.viij. en .viij. } \\
\text { dies }\end{array}$ & \\
\hline
\end{tabular}

I58. At this point $P$ inserts two anomolous chapters attributed to Solomon: "De carabaçes. Diu salamo que si tu vols fer vna gran carabaça molt larga, pren dela sement deles carabaçes redones e en vna canasta que sia plena de fem podrit e alli planta aquella sement en lo mes de febrer. E quant seran exides que seran de .iiij. o .v. fulles tresplantaras a cascuna a sa part ab molt fem e regales souent. E quant hi aura dos o tres carabaçes axj com lo puny colljrles has totes sino aquella quit parra molt bella e tu volras jaqujr per ferla molt largua. E puys fes hun gran clot en terra e met la carabaça damunt algun faix de sarments e que tinga lo cul la volta del clot fet en terra e puys cobre la carabaça de frasques e barumballa per manera que lo sol nj fret noli faça mal e lexa la estar axj que si lo clot es fons vna cana se fara longa la carabaça. Mas guarda enlo clot noy entre aygua mas rega la planta dela carabaça. E aço es prouat moltes vegades. Mas nota que en totes les plantes o planta noy aja altra carabaça sino aquella. De fer menta. Encara posa lo sauj Salamo que quj vol fer menta, o erba de senta marja, la qual menta com hes manifest a tot lo mon no fa may semença, e no podent aver dela sua semença o natura, mostra açj Salamo en qual manera se pot fer. Diu que si es presa vna corda despart e com vjngua enlo mes de maig o de juny sia huntada aquella de mel e posala en lloch hon hi puguen venjr mosques a mengar aquella mel, e com veus aquella es la condiçjo della mosca que alla hon ve a menjar alli caga moltes voltes e com aquella corda sia ben plena deles caguadures deles mosques sotarrarlas [sic] de jus terra e regar las e en continent a pochs dies auras molta erba de santa marja o menta ques nomena en hulguar. E es sertament cosa prouada" ( $P$ f. $\left.59^{-}-59 v\right)$.

I59. Immediately following this second chapter on lettuce $(54 \mathrm{v}), N$ includes a chapter on fava beans not found in any other witness: "Faues. Ffaues comunament se planten os sembren a Sant Miquel. Quj les vol primerenques plantales hom en Agost o en setembre en la prjmera setmana". All the chapters that follow these brief instructions on fava cultivation treat non-horticultural topics (grafting, planting trees, etc.).

I6o. After the first two paragraphs on lettuce (24r), Agustí I6I7 cites extensively other authors on the same crop and its medicinal uses $(24 \mathrm{~V})$, then four other chapters follow, none of which correspond to any of the Memòria texts known so far: one on "Secrets pera fer las bledas blancas y grossas" $(25$ r) taken from sources named in the margin as Sossio, Mizaldo, and Esteua; one on "Secret per fer que lo iulivert fassa las fullas molt amples..." (25r) citing other sources; one on "Secrets pera fer naxer molts esparechs..." (25v), citing still other sources, and one on "De sembrar lo canem y lo lli” (25v), which cites no source. Agustí r626 has three chapters (on borrajas 'borage', oruca 'arugula' and cardos 'artichoke') in place of these last two. The Memòria material then resumes, with the chapter on leeks in Agustí I6I7 (25v, see below) and on onions in Agustí I626 (p. 86). 


\begin{tabular}{|c|c|c|c|c|c|c|}
\hline $\begin{array}{l}\text { M(Madrid) } \\
\text { BNE IO2II }\end{array}$ & $\begin{array}{l}V \text { (Valencia) } \\
\text { BMSM 6437 }\end{array}$ & $\begin{array}{l}A \text { (Annapo- } \\
\text { lis) MS Gwara }\end{array}$ & $\begin{array}{l}P \text { (Paris) BnF } \\
\text { esp. 29I }\end{array}$ & $\begin{array}{l}B \text { (Barcelo- } \\
\text { na) BCB } 754\end{array}$ & $\begin{array}{l}N \text { (Naples) } \\
\text { Branc III AII }\end{array}$ & $\begin{array}{l}\text { Miquel } \\
\text { Agustí I6I? }\end{array}$ \\
\hline $\begin{array}{l}\text { E pueden se } \\
\text { trasplantar } \\
\text { en enero } \\
\text { o plantar. } \\
\text { Empero los } \\
\text { tempranos han } \\
\text { avantaja que } \\
\text { se fazen mas } \\
\text { bellos \& no } \\
\text { temen tanto la } \\
\text { Niebla de mayo } \\
\text { como los otros. } \\
\\
54\end{array}$ & $\begin{array}{l}\text { y podense } \\
\text { tresplantar en } \\
\text { giner o plantar } \\
\text { empero los } \\
\text { primerenchs se } \\
\text { fan pus bells }\end{array}$ & & \begin{tabular}{|l|} 
e si nols \\
plantaues \\
en deembre \\
plantals en \\
jener en luna \\
vella, \\
mas mes valen \\
los primers per \\
que la lluna \\
de maig molt \\
los pot noure \\
e per aço val \\
molt que sien ja \\
crescuts \\
\end{tabular} & \begin{tabular}{|l|} 
E si nols \\
planta hom \\
de dehembre \\
planteles hom \\
de Giner en la \\
Luna vella \\
mas mes \\
valen los \\
primarenchs de \\
dehembre per \\
ço com la Luna \\
de maig nols \\
pot noure per \\
ço com son ya \\
crescuts \\
\end{tabular} & \begin{tabular}{|l} 
e si son \\
plantats \\
prjmerenchs \\
valen mes e no \\
temen la neula \\
de Maig.
\end{tabular} & $\begin{array}{l}\text { sinols plantau } \\
\text { de Nouembra } \\
\text { los podreu } \\
\text { plantar de } \\
\text { Ianer, } \\
\text { pero valen } \\
\text { molt mes los } \\
\text { primarenchs: } \\
\text { perque la } \\
\text { neula, que fa de } \\
\text { Maig, nols pot } \\
\text { danyar, per ser } \\
\text { ya grans, }\end{array}$ \\
\hline 55 & & & \begin{tabular}{|l|} 
e si entre ells \\
vols plantar \\
o sembrar \\
alguns grans \\
despinachs \\
fançj molt \\
bells. Axj \\
mateix algunes \\
lletugues, e fan \\
si molt belles. \\
\end{tabular} & \begin{tabular}{|l} 
E quis vol be \\
pot sembrar \\
entre los alls \\
primarenchs \\
alguns grans \\
de spinachs e \\
fan se fort bells \\
e de letugues e \\
fan se belles
\end{tabular} & & $\begin{array}{l}\text { Ab los } \\
\text { primarenchs } \\
\text { de Nouembra, } \\
\text { podeu } \\
\text { sembrar gra } \\
\text { de Espinachs, } \\
\text { ò de Lletugas, } \\
\text { que si fan molt } \\
\text { be entre ells. } \\
(\ldots . .)\end{array}$ \\
\hline $5^{6}$ & & & \begin{tabular}{|l|} 
e si vols que \\
los alls no \\
grjllen fes que \\
sien plantats \\
en luna vella e \\
arencalos en \\
luna noua e si \\
son plantats \\
en luna noua \\
arencalos en \\
luna vella
\end{tabular} & $\begin{array}{l}\text { Si vols quels } \\
\text { alls no grilen } \\
\text { fes que si } \\
\text { los alls son } \\
\text { plantats en } \\
\text { Luna vella } \\
\text { arranquals en } \\
\text { Luna noua e } \\
\text { si son plantats } \\
\text { en Luna noua } \\
\text { arranquals en } \\
\text { Luna vella } \\
\end{array}$ & & \\
\hline 57 & & & \begin{tabular}{|l|} 
E nota que com \\
los plantaras \\
volen esser \\
solament hun \\
gra dall e de \\
gra en gra axj \\
fan a plantar ${ }^{6 \mathrm{r}}$ \\
\end{tabular} & & & \\
\hline
\end{tabular}

I6r. Here $P$ inserts (f. 6or-6ov): "E si per ventura voljes fer de huna cabesa dalls que vjngues axj groça com lo puny o pus gros pendras lo gra del all e foradarlas ab huna estaqua que sia molt prima pero que lo forat nolj pas e puys dins aquell forat metras [fol. 6ov] hun gra de senapi e puys planta ton all e faras molt gros. Pero nota que sempre la sua sabor tira al senapi pero es molt bella cossa". 


\begin{tabular}{|c|c|c|c|c|c|c|}
\hline $\begin{array}{l}\text { M(Madrid) } \\
\text { BNE IO2II }\end{array}$ & $\begin{array}{l}V \text { (Valencia) } \\
\text { BMSM 6437 }\end{array}$ & $\begin{array}{l}A \text { (Annapo- } \\
\text { lis) MS Gwara }\end{array}$ & $\begin{array}{l}\text { P(Paris) BnF } \\
\text { esp. 29I }\end{array}$ & $\begin{array}{l}B \text { (Barcelo- } \\
\text { na) BCB } 754\end{array}$ & $\begin{array}{l}N \text { (Naples) } \\
\text { Branc III AII }\end{array}$ & $\begin{array}{l}\text { Miquel } \\
\text { Agustí I6I? }\end{array}$ \\
\hline $5^{8}$ & & & $\begin{array}{l}\text { De plantar } \\
\text { scalunyes. } \\
\text { Si vols fer } \\
\text { escalunyes } \\
\text { pendras una } \\
\text { seba e talla } \\
\text { lj molt be les } \\
\text { rahels e apres } \\
\text { despulla la } \\
\text { en manera } \\
\text { que la terça } \\
\text { part ne vaga } \\
\text { en aquella } \\
\text { despulla } \\
\text { pero que la } \\
\text { seba començ } \\
\text { agrillar e } \\
\text { despulla la } \\
\text { tant fins que } \\
\text { lo grill te } \\
\text { romanga redo } \\
\text { e puys pren } \\
\text { grans dalls } \\
\text { e fiquals en } \\
\text { aquell grill } \\
\text { en tant que nj } \\
\text { metes tres o } \\
\text { quatre e cubrj } \\
\text { los de terra } \\
\text { e axj auras } \\
\text { escalunyes. }\end{array}$ & $\begin{array}{l}\text { [5.I4] Si vols } \\
\text { fer scalunyes } \\
\text { hages vna } \\
\text { ceba e tall les } \\
\text { rahils e apres } \\
\text { leuen la terra } \\
\text { part dela ceba } \\
\text { enues lo grill } \\
\text { en rodo e ficalj } \\
\text { grans de alls } \\
\text {.iij. o.iiij. e } \\
\text { cobren de } \\
\text { terra e hauras } \\
\text { scalunyes }\end{array}$ & & \\
\hline 59 & & & $\begin{array}{l}\text { E puys com } \\
\text { ne tingues } \\
\text { una mata } \\
\text { ne tendras } \\
\text { moltes, ço es, } \\
\text { que tingues } \\
\text { soterrada } \\
\text { aquella planta } \\
\text { dejus terra } \\
\text { e com vinga } \\
\text { en lo mes de } \\
\text { maig traules } \\
\text { e departexles } \\
\text { de cap en cap } \\
\text { e puys planta } \\
\text { cascun cap per } \\
\text { si e de cascun } \\
\text { cap auras una } \\
\text { planta. Cosa } \\
\text { provada. }\end{array}$ & $\begin{array}{l}\text { Jtem en apres } \\
\text { altre manera } \\
\text { pren deles } \\
\text { scalunyes vna } \\
\text { mota e lexa les } \\
\text { deuall terra e } \\
\text { en lo mes de } \\
\text { Maig trau les } \\
\text { dela mota fen } \\
\text { de cascuna } \\
\text { scalunya sa } \\
\text { part e planta } \\
\text { cascuna per } \\
\text { si e fer sa } \\
\text { de cascuna } \\
\text { scalunya huna } \\
\text { mota }\end{array}$ & & \\
\hline
\end{tabular}




\begin{tabular}{|c|c|c|c|c|c|c|}
\hline $\begin{array}{l}\text { M(Madrid) } \\
\text { BNE IO2II }\end{array}$ & $\begin{array}{l}V \text { (Valencia) } \\
\text { BMSM 6437 }\end{array}$ & $\begin{array}{l}A \text { (Annapo- } \\
\text { lis) MS Gwara }\end{array}$ & $\begin{array}{l}P \text { (Paris) BnF } \\
\text { esp. 29I }\end{array}$ & $\begin{array}{l}B \text { (Barcelo- } \\
\text { na) BCB } 754\end{array}$ & $\begin{array}{l}N \text { (Naples) } \\
\text { Branc III AII }\end{array}$ & $\begin{array}{l}\text { Miquel } \\
\text { Agustí I6I7 }\end{array}$ \\
\hline $\begin{array}{l}\text { Rauanos } \\
\text { planta } \\
\text { hombre todo } \\
\text { el Añyo. mas } \\
\text { en espeçial } \\
\text { quieren quelos } \\
\text { planten en } \\
\text { março \& } \\
\text { en julio. E } \\
\text { quieren tierra } \\
\text { bien labrada } \\
\text { menos de } \\
\text { estiercol. }\end{array}$ & $\begin{array}{l}\text { Rauens planta } \\
\text { hom tot lany } \\
\text { en especial } \\
\text { valen mes } \\
\text { aquells ques } \\
\text { planten en } \\
\text { març y de } \\
\text { Joliol y volen } \\
\text { terra ben } \\
\text { llaurada sens } \\
\text { fems }\end{array}$ & & & $\begin{array}{l}\text { [5.I8] De } \\
\text { Rauens. } \\
\text { Rauens se } \\
\text { poden plantar } \\
\text { per tot lany } \\
\text { mas mes valen } \\
\text { aquells quj son } \\
\text { plantats en lo } \\
\text { mes de març e } \\
\text { no volen fems } \\
\text { mas volen } \\
\text { terra ben } \\
\text { cauada e be } \\
\text { toua Rauens } \\
\text { plantats en lo } \\
\text { mes de Juliol } \\
\text { valen mes e } \\
\text { son millors del } \\
\text { any Los vns } \\
\text { e los altres se } \\
\text { volen reguar } \\
\text { aueguades } \\
\text { Rauens no deu } \\
\text { hom per ells } \\
\text { triar terra com } \\
\text { baste a hom } \\
\text { qui nols vol } \\
\text { vendre que en } \\
\text { los camps de } \\
\text { les cols ne fasa } \\
\text { hom plantar }\end{array}$ & $\begin{array}{l}{\left[54^{\mathrm{v}]} \text { Rauens }\right.} \\
\text { bons. Rauens } \\
\text { podets plantar } \\
\text { tot lany en } \\
\text { special en lo } \\
\text { mes de mars } \\
\text { mas mes valen } \\
\text { aquells que } \\
\text { son plantats } \\
\text { en lo mes de } \\
\text { Juliol. No } \\
\text { volen fems } \\
\text { mas terra ben } \\
\text { cauada. E } \\
\text { deuen regar } \\
\text { a vegades. E } \\
\text { es cert quels } \\
\text { millors rauens } \\
\text { de tot lany } \\
\text { son aquells } \\
\text { quis planten } \\
\text { en Juliol. Per } \\
\text { rauens no cal } \\
\text { triar terra car } \\
\text { basten per } \\
\text { acasa qui non } \\
\text { vol vendre } \\
\text { quen mete } \\
\text { hom enels } \\
\text { crestes dels } \\
\text { solchs deles } \\
\text { cols. }\end{array}$ & $\begin{array}{l}\text { [fol. } 27 \mathrm{r}] \\
\text { Secrets } \\
\text { dels ravens. } \\
\text { Sembrar } \\
\text { poreu tot lo } \\
\text { any Rauens, } \\
\text { pero son } \\
\text { millors los que } \\
\text { sembrareu de } \\
\text { Iuliol, apres } \\
\text { los de Mars, } \\
\text { no volen fems, } \\
\text { sino terra ben } \\
\text { cauada, se han } \\
\text { de sembrar } \\
\text { en Lluna } \\
\text { vella, y qui } \\
\text { nols vol pera } \\
\text { vendre, basta } \\
\text { sembrarne } \\
\text { als solchs } \\
\text { de las Cols, } \\
\text { Porros, y dels } \\
\text { Espinachs. } \\
\text { (...) }\end{array}$ \\
\hline $\begin{array}{l}\text { Puerros } \\
\text { \& çebolla } \\
\text { porrera } \\
\text { siembra } \\
\text { hombre en } \\
\text { luna vieja } \\
\text { de mediante } \\
\text { março fasta a } \\
\text { mediant mayo }\end{array}$ & $\begin{array}{l}\text { Porros y } \\
\text { çeba porrera } \\
\text { se senbra a } \\
\text { mijant març }\end{array}$ & & $\begin{array}{l}\text { De plantar } \\
\text { e sembrar } \\
\text { porros. } \\
\text { La sement } \\
\text { dels porros } \\
\text { e de sebes } \\
\text { sembra hom } \\
\text { a l'entrant de } \\
\text { marc en luna } \\
\text { vella fins al } \\
\text { migant del dit } \\
\text { mes e no se } \\
\text { poden cremar } \\
\text { per lo fret. }\end{array}$ & $\begin{array}{l}\text { [5.I5] Porros } \\
\text { e cebes e } \\
\text { porrella } \\
\text { sembra hom } \\
\text { en lentrant de } \\
\text { març en la luna } \\
\text { vella tro mijant } \\
\text { març }\end{array}$ & & $\begin{array}{l}\text { [fol. } 25 \mathrm{v}] \\
\text { Secrets de } \\
\text { las raels de } \\
\text { las herbas } \\
\text { de Ortalisas. } \\
\text { Cap. V. } \\
\text { Secrets dels } \\
\text { Porrosy } \\
\text { del temps } \\
\text { que se han } \\
\text { de sembrar } \\
\text { y plantar. } \\
\text { [fol. } 26 r \text { r Los } \\
\text { Porros se han } \\
\text { de sembrar en } \\
\text { lo mes de Mars }\end{array}$ \\
\hline
\end{tabular}




\begin{tabular}{|c|c|c|c|c|c|c|}
\hline $\begin{array}{l}\text { M(Madrid) } \\
\text { BNE IO2II }\end{array}$ & $\begin{array}{l}V \text { (Valencia) } \\
\text { BMSM 6437 }\end{array}$ & $\begin{array}{l}A \text { (Annapo- } \\
\text { lis) MS Gwara }\end{array}$ & $\begin{array}{l}P \text { (Paris) BnF } \\
\text { esp. 29I }\end{array}$ & $\begin{array}{l}B \text { (Barcelo- } \\
\text { na) BCB } 754\end{array}$ & $\begin{array}{l}N \text { (Naples) } \\
\text { Branc III AII }\end{array}$ & $\begin{array}{l}\text { Miquel } \\
\text { Agustí I6I7 }\end{array}$ \\
\hline $\begin{array}{l}\text { Empero la } \\
\text { çebolla faze } \\
\text { a sembrar } \\
\text { rralota } \\
62\end{array}$ & $\begin{array}{l}\text { Empero } \\
\text { la çeba fa } \\
\text { a sembrar } \\
\text { clareta }\end{array}$ & & $\begin{array}{l}\text { Empero la } \\
\text { seba se vol } \\
\text { sembrar } \\
\text { clareta }\end{array}$ & $\begin{array}{l}\text { La ceba fa } \\
\text { a sembrar } \\
\text { clareta }\end{array}$ & & \\
\hline 63 & & & $\begin{array}{l}\text { per que faça } \\
\text { mes groça [fol. } \\
\text { 6rr] e bella e } \\
\text { fa molt bella } \\
\text { mata }\end{array}$ & $\begin{array}{l}\text { per ço que } \\
\text { meta mjllor } \\
\text { mata }\end{array}$ & & \\
\hline $\begin{array}{l}\text { en buena era } \\
\text { con estiercol } \\
\text { conuenjente } \\
\text { mente \& non } \\
\text { mucho. E faze } \\
\text { rregar dos dias } \\
\text { enla semana o } \\
\text { tres. } \\
64 \\
\end{array}$ & $\begin{array}{l}\text { en bon guaret } \\
\text { ab fems } \\
\text { couinentment } \\
\text { y fa a regar } \\
\text {.ij. dies en la } \\
\text { setmana }\end{array}$ & & $\begin{array}{l}\text { e vol bona } \\
\text { terra e de bona } \\
\text { gujssa lo fem. } \\
\text { E fan a regar } \\
\text { de dos en dos } \\
\text { dies }\end{array}$ & $\begin{array}{l}\text { e volen bon } \\
\text { guoret e no } \\
\text { massa fems e } \\
\text { fan a reguar de } \\
\text {.ij. en .ij djes la } \\
\text { setmana }\end{array}$ & & $\begin{array}{l}\text { [fol. } 25 \mathrm{v}] \text { en } \\
\text { terra ben } \\
\text { cauada, y } \\
\text { ab fems, no } \\
\text { desmasiats en } \\
\text { Lluna vella, }{ }^{162}\end{array}$ \\
\hline 65 & & & \begin{tabular}{|l} 
e mes si \\
mester ho \\
auran. ${ }^{6}{ }^{63}$ \\
\end{tabular} & $\begin{array}{l}\text { o mes si ops o } \\
\text { han. }\end{array}$ & & \\
\hline $\begin{array}{l}\text { empero los } \\
\text { puerros } \\
\text { quieren } \\
\text { mucho } \\
\text { estiercol } \\
66 \\
\end{array}$ & $\begin{array}{l}\text { empero los } \\
\text { porros volen } \\
\text { molts fems }\end{array}$ & & & & & \\
\hline $\begin{array}{l}\text { E fazen a } \\
\text { trasplantar } \\
\text { los puerros } \\
\text { Asy como } \\
\text { la çebolla } \\
\text { porrera de } \\
\text { mediante } \\
\text { Agosto fasta } \\
\text { mediante } \\
\text { setiembre en } \\
\text { luna vieja. } \\
67\end{array}$ & $\begin{array}{l}\text { y fan a } \\
\text { tresplantar } \\
\text { los porros axi } \\
\text { com la çeba } \\
\text { porrera de } \\
\text { mijant agost } \\
\text { fins mijant } \\
\text { setembre en } \\
\text { lluna vella }\end{array}$ & & $\begin{array}{l}\text { E puys fan a } \\
\text { tresplantar en } \\
\text { maig o en juny } \\
\text { en luna vella }\end{array}$ & $\begin{array}{l}\text { E fan a } \\
\text { tresplantar } \\
\text { mijant Agost } \\
\text { en la Luna } \\
\text { vella. }\end{array}$ & & \\
\hline
\end{tabular}

I62. Here Agustí I6Iz inserts (f. 25v) “y tambe de mes primarenchs en lo mes de Ianer y Febrer: per hauer llauor de ells per tenirne en lo estiu, se plantaran en lo Abril, Maig, ó Iuny: per tenirne en lo hiuern se plantaran en lo Agost, Setembre y Octubre. (...)"

I63 Here $P$ inserts (6Ir): "E dien alguns que hom deu cauar la lleuada e ben plana e sembrada de bon fem ben podrit, e despuys sia homplit aquella leuada de aygua e ab aquella aygua sembra la llauor dela seba e vendran molt millor". 


\begin{tabular}{|c|c|c|c|c|c|c|}
\hline $\begin{array}{l}\text { M(Madrid) } \\
\text { BNE IO2II }\end{array}$ & $\begin{array}{l}V \text { (Valencia) } \\
\text { BMSM 6437 }\end{array}$ & $\begin{array}{l}A \text { (Annapo- } \\
\text { lis) MS Gwara }\end{array}$ & $\begin{array}{l}\text { P(Paris) BnF } \\
\text { esp. 29I }\end{array}$ & $\begin{array}{l}B \text { (Barcelo- } \\
\text { na) BCB } 754\end{array}$ & $\begin{array}{l}N \text { (Naples) } \\
\text { Branc III AII }\end{array}$ & $\begin{array}{l}\text { Miquel } \\
\text { Agustí I6I? }\end{array}$ \\
\hline $\begin{array}{l}\text { E los puerros } \\
\text { al trasplan- } \\
\text { tar quieren } \\
\text { mucho } \\
\text { estiercol } \\
68\end{array}$ & $\begin{array}{l}\text { y los porros } \\
\text { al tresplantar } \\
\text { volen molts } \\
\text { fems }\end{array}$ & & $\begin{array}{l}\text { mas si vols } \\
\text { bons porros } \\
\text { tresplantalos } \\
\text { en maig e } \\
\text { alagost quant } \\
\text { los volras } \\
\text { tresplantar } \\
\text { seran bells e } \\
\text { groços apres } \\
\text { met hi hom } \\
\text { molt fem }\end{array}$ & $\begin{array}{l}\text { Los porros } \\
\text { volen fems al } \\
\text { tresplantar }\end{array}$ & & \\
\hline 69 & & & & $\begin{array}{l}\text { Mas ala [space } \\
\text { left blank] no } \\
\text { cal fems mas } \\
\text { vol terra be } \\
\text { cauada }\end{array}$ & & \\
\hline $\begin{array}{l}\text { Eque sean } \\
\text { espesos. } \\
70\end{array}$ & $\begin{array}{l}\text { y que sien } \\
\text { espessos }\end{array}$ & & & $\begin{array}{l}\text { com tresplanta } \\
\text { hom los } \\
\text { porros volen } \\
\text { que hom los } \\
\text { planta spessos }\end{array}$ & & \\
\hline 7I & & & $\begin{array}{l}\text { e fes per } \\
\text { manera que de } \\
\text { hun porro a } \\
\text { laltre aja dos o } \\
\text { tres dits }\end{array}$ & $\begin{array}{l}\text { que no hage } \\
\text { de hun al altre } \\
\text { mes de hun djt }\end{array}$ & & \\
\hline $\begin{array}{l}\text { E que ayan } \\
\text { agua de tres en } \\
\text { tres dias. fasta } \\
\text { tanto que sean } \\
\text { presos. } \\
7^{2}\end{array}$ & $\begin{array}{l}\text { y que hagen } \\
\text { aygua de iij. en } \\
\text { iij. [dies] [fol. } \\
95 \text { v] fins que } \\
\text { sien preses }\end{array}$ & & $\begin{array}{l}\text { e sien regats } \\
\text { hun dia pert } \\
{[s i c] \text { altre }} \\
\text { fins a tres } \\
\text { regadures. }\end{array}$ & $\begin{array}{l}\text { e volen aygua } \\
\text { de .iij. en iij. } \\
\text { djes tro sien } \\
\text { presos. }\end{array}$ & & \\
\hline Las cebollas & les çebes & & $\begin{array}{l}\text { La seba deus } \\
\text { tresplantar } \\
\text { en maig fins } \\
\text { mggant lo mes } \\
\text { de juny en } \\
\text { luna plena e } \\
\text { apres la met } \\
\text { dejus terra } \\
\text { ab molt fem } \\
\text { mesclat ab la } \\
\text { terra }\end{array}$ & La ceba & & \\
\hline $\begin{array}{l}\text { non qujeren } \\
\text { mucho } \\
\text { estiercol } \\
\text { synon que } \\
\text { sean rralas } \\
\text { mas quelos } \\
\text { puerros } \\
74\end{array}$ & $\begin{array}{l}\text { no volen molts } \\
\text { fems que sien } \\
\text { clares mes } \\
\text { quels porros }\end{array}$ & & & $\begin{array}{l}\text { nos vol } \\
\text { tresplantar tan } \\
\text { spes mas be } \\
\text { vol que hom } \\
\text { la plant spes } \\
\text { coujnentment }\end{array}$ & & \\
\hline
\end{tabular}




\begin{tabular}{|c|c|c|c|c|c|c|}
\hline $\begin{array}{l}\text { M(Madrid) } \\
\text { BNE IO2II }\end{array}$ & $\begin{array}{l}V \text { (Valencia) } \\
\text { BMSM 6437 }\end{array}$ & $\begin{array}{l}A \text { (Annapo- } \\
\text { lis) MS Gwara }\end{array}$ & $\begin{array}{l}\text { P(Paris) BnF } \\
\text { esp. 29I }\end{array}$ & $\begin{array}{l}B \text { (Barcelo- } \\
\text { na) BCB } 754\end{array}$ & $\begin{array}{l}N \text { (Naples) } \\
\text { Branc III AII }\end{array}$ & $\begin{array}{l}\text { Miquel } \\
\text { Agustí I6I? }\end{array}$ \\
\hline 75 & & & & $\begin{array}{l}\text { mas puys son } \\
\text { preses }\end{array}$ & & \\
\hline $\begin{array}{l}\text { E agua dos } \\
\text { vezes en la } \\
\text { semana. } \\
{ }_{7} 6\end{array}$ & $\begin{array}{l}\text { y aygua dos } \\
\text { vegades la } \\
\text { setmana }\end{array}$ & & $\begin{array}{l}\text { e regales de } \\
\text { dos en dos } \\
\text { dies. }\end{array}$ & $\begin{array}{l}\text { volen se reguar } \\
\text { ij. vegades la } \\
\text { setmana }\end{array}$ & & \\
\hline 77 & & & $\begin{array}{l}\text { Les primeres } \\
\text { vegades } \\
\text { se volen } \\
\text { entrecauar } \\
\text { molt }\end{array}$ & & & \\
\hline $7^{8}$ & & & & $\begin{array}{l}\text { E fan a plantar } \\
\text { present }[s i c] \\
\text { los porros } \\
\end{array}$ & & \\
\hline $\begin{array}{l}\text { E los surcos } \\
\text { delos puerros } \\
\text { sean bien } \\
\text { anchos. } \\
79\end{array}$ & $\begin{array}{l}\text { y los solchs } \\
\text { dels porros } \\
\text { sien ben } \\
\text { amples }\end{array}$ & & $\begin{array}{l}\text { e tresplantales } \\
\text { que aja hun } \\
\text { bon forch o } \\
\text { una ma de una } \\
\text { al altra e seran } \\
\text { belles }^{16_{4}}\end{array}$ & $\begin{array}{l}\text { e de hun solch } \\
\text { a altre hage dos } \\
\text { palms }\end{array}$ & & \\
\hline $\begin{array}{l}\text { E pueden } \\
\text { sembrar por } \\
\text { medio delos } \\
\text { rrauanos. } \\
80 \\
\end{array}$ & $\begin{array}{l}\text { E poden } \\
\text { sembrar per } \\
\text { mig dells } \\
\text { rauens }\end{array}$ & & & $\begin{array}{l}\text { E quis vol pot } \\
\text { plantar cols e } \\
\text { rauens e fan se } \\
\text { molt be entre } \\
\text { los porros }\end{array}$ & & \\
\hline 8I & & & & $\begin{array}{l}\text { E los } \\
\text { porros fan a } \\
\text { entracauar [fol. } \\
\text { I2Ir] e cullir ab } \\
\text { terra axi com } \\
\text { los porros }{ }^{165} \\
\end{array}$ & & \\
\hline \begin{tabular}{l|} 
Cebolla \\
rredonda \\
de saluar se \\
deue sembrar \\
en luna vieja \\
mediante enero \\
en buenas eras \\
bien cauadas \& \\
con estiercol. \\
82 \\
2
\end{tabular} & $\begin{array}{l}\text { Ceba redona } \\
\text { de saluar se } \\
\text { deu sembrar } \\
\text { en lluna vella } \\
\text { mijant giner en } \\
\text { bon guaret ab } \\
\text { fems }\end{array}$ & & & \begin{tabular}{|l|} 
[5.16] De \\
cebes rodones \\
de Saluar. \\
Ceba rodona \\
de saluar \\
sembra hom \\
mijant Giner en \\
Luna Vella e en \\
guaret ben fet \\
ab molts fems \\
\end{tabular} & & $\begin{array}{l}\text { [fol. } 26 \mathrm{r}] \\
\text { Secrets de la } \\
\text { ceba rodona } \\
\text { per salvar. La } \\
\text { Ceba rodona } \\
\text { per saluar se } \\
\text { sembra en lo } \\
\text { mes de Ianer } \\
\text { en Lluna vella }\end{array}$ \\
\hline
\end{tabular}

I64. Here $P$ inserts (6rr): "yo he vist que com son axj com la gruyxessa de hun bou les descalsen de la terra e fan sen molt groses e es prouat. E si vols que no grillen axj prest com les enforcaras per volerles saluar leuals ab un gaujnet totes les barbes, ço es, les rahels. [fol. 6rv] E puys met hun ferro en lo foch e com sera molt e ben vermell crema alla hon an estat les barbes e puys met les a saluar e aço val molt que no grjllen axj prest".

I65. Here $B$ inserts (І2 Ir): "E la lauor dels porros e deles cebes pot hom axi tenir que la hon tresplantats leix hom hun solch o dos aytants com hom se vulla los quals spiguen e leix hom assahonar la lauor e que hom la stoig be". 


\begin{tabular}{|c|c|c|c|c|c|c|}
\hline $\begin{array}{l}\text { M(Madrid) } \\
\text { BNE IO2II }\end{array}$ & $\begin{array}{l}V \text { (Valencia) } \\
\text { BMSM 6437 }\end{array}$ & $\begin{array}{l}\text { A (Annapo- } \\
\text { lis) MS Gwara }\end{array}$ & $\begin{array}{l}P \text { (Paris) BnF } \\
\text { esp. 29I }\end{array}$ & $\begin{array}{l}\text { B (Barcelo- } \\
\text { na) BCB } 754\end{array}$ & $\begin{array}{l}N \text { (Naples) } \\
\text { Branc III AII }\end{array}$ & $\begin{array}{l}\text { Miquel } \\
\text { Agustí I6I? }\end{array}$ \\
\hline 83 & & & & & & $\begin{array}{l}\text { per ser } \\
\text { primarenca, } \\
\text { y sen sembra } \\
\text { de Febrer, y } \\
\text { de Mars, en } \\
\text { bona terra, y } \\
\text { ben femada, } \\
\text { y es molt bo } \\
\text { destrempar ab } \\
\text { aygua ab vna } \\
\text { Samal fempta } \\
\text { de Coloms, } \\
\text { ó de Gallina, } \\
\text { y femarne la } \\
\text { terra, }\end{array}$ \\
\hline $\begin{array}{l}\text { E rregar } \\
\text { muchas vezes } \\
84\end{array}$ & $\begin{array}{l}\text { fa a regar } \\
\text { souint }\end{array}$ & & & $\begin{array}{l}\text { e regals hom } \\
\text { souin }\end{array}$ & & \begin{tabular}{|l|} 
vol regarse \\
souint,
\end{tabular} \\
\hline 85 & & & & & & $\begin{array}{l}\text { y per guardarla } \\
\text { de fret, y } \\
\text { gelades, fareu } \\
\text { los remeys que } \\
\text { tenim dits, }\end{array}$ \\
\hline 86 & & & & $\begin{array}{l}\text { e tresplanta la } \\
\text { hom com es } \\
\text { creguda } \\
\end{array}$ & & \\
\hline $\begin{array}{l}\text { E deue se } \\
\text { trasplantar en } \\
\text { abril E en mayo } \\
\text { en luna vieja. }\end{array}$ & \begin{tabular}{|l} 
y deuse \\
tresplantar en \\
abril en maig \\
enla lluna vella
\end{tabular} & & & \begin{tabular}{|l|} 
E decontinent \\
que hom veu \\
que es bona a \\
tresplantar en \\
Abril o en maig \\
mas com pus \\
primarencha \\
se plantara \\
ço es en Maig \\
mes val fa a \\
tresplantar enla \\
luna vella \\
\end{tabular} & & \begin{tabular}{|l} 
y quant veureu \\
sera bona à \\
tras- [fol. 26v] \\
plantar, que \\
sera en lo mes \\
de Abril, ò \\
de Maig, que \\
quant mes \\
primarenca es, \\
mes val, ${ }^{166}$
\end{tabular} \\
\hline $\begin{array}{l}\text { Empero } \\
\text { el palladio } \\
\text { dize que en } \\
\text { luna que sea } \\
\text { nueua faze a } \\
\text { trasplantar } \\
\text { menos de } \\
\text { estiercol. } \\
88\end{array}$ & $\begin{array}{l}\text { Empero lo } \\
\text { palladi diu } \\
\text { que en lluna } \\
\text { vella que sia } \\
\text { noua [sic] fa } \\
\text { a tresplantar } \\
\text { sens fems }\end{array}$ & & & & & \\
\hline
\end{tabular}

I66. Here Agustí I6r7 inserts (26v): “y quant la transplantareu tallarlos totas las raels perque ne fassen de nouas, y regareulas, sinols lleuau las raels, quant las haureu plantades, dexareu de regarlas deu, ò dotze dias, y en estos dias las raels sels moriran, y apres regaules y posaran raels nouas, y se faran molt millors”. 


\begin{tabular}{|c|c|c|c|c|c|c|}
\hline $\begin{array}{l}\text { M(Madrid) } \\
\text { BNE IO2II }\end{array}$ & $\begin{array}{l}\text { V(Valencia) } \\
\text { BMSM 6437 }\end{array}$ & $\begin{array}{l}A \text { (Annapo- } \\
\text { lis) MS Gwara }\end{array}$ & $\begin{array}{l}P(\text { Paris) BnF } \\
\text { esp. 29I }\end{array}$ & $\begin{array}{l}B \text { (Barcelo- } \\
\text { na) BCB } 754\end{array}$ & $\begin{array}{l}N \text { (Naples) } \\
\text { Branc III AII }\end{array}$ & $\begin{array}{l}\text { Miquel } \\
\text { Agustí I6I7 }\end{array}$ \\
\hline $\begin{array}{l}\text { E non quiere } \\
\text { estar fonda. } \\
\text { sinon que } \\
\text { solament sea } \\
\text { cubierta. E } \\
\text { faze a rregar } \\
\text { de tres en tres } \\
\text { dias }\end{array}$ & $\begin{array}{l}\text { y nos vol metre } \\
\text { fondo sino que } \\
\text { solament sia } \\
\text { cubert y fa a } \\
\text { regar de .iij. } \\
\text { en .iij. dies }\end{array}$ & & & $\begin{array}{l}\text { e mesa com } \\
\text { pus som pot } \\
\text { hom per ço } \\
\text { com millor } \\
\text { ceba met e } \\
\text { bastalj que } \\
\text { solament sia } \\
\text { cuberta de } \\
\text { terra la caboça } \\
\text { No vol fems } \\
\text { al tresplantar } \\
\text { mas vol ne al } \\
\text { sembrar axi } \\
\text { com damunt } \\
\text { hauem dit e fa } \\
\text { areguar pus es } \\
\text { tresplantada } \\
\text { de .iij. en .iij. } \\
\text { dies }\end{array}$ & & $\begin{array}{l}\text { y fan a plantar } \\
\text { molt somas } \\
\text { que basta la } \\
\text { cabeça sia } \\
\text { cuberta de } \\
\text { terra, y al } \\
\text { transplantar, } \\
\text { no volen molt } \\
\text { fems, fan a } \\
\text { regar souint, }\end{array}$ \\
\hline $\begin{array}{l}\text { E que el } \\
\text { tiempo sea } \\
\text { claro. E qujere } \\
\text { se entreca-uar } \\
\text { de ocho en } \\
\text { ocho dias. } \\
\text { 9o }\end{array}$ & $\begin{array}{l}\text { y vol se } \\
\text { entrecauar de } \\
\text { viij. en .viij. } \\
\text { dies }\end{array}$ & & & $\begin{array}{l}\text { e de } \\
\text { entracauar } \\
\text { hun dja la } \\
\text { setmana } \\
\text { Guardar se } \\
\text { deu hom com } \\
\text { la regua que la } \\
\text { hora sia clara }\end{array}$ & & $\begin{array}{l}\text { y a recauar vn } \\
\text { dia la setmana, } \\
\text { y quant las } \\
\text { regareu, que } \\
\text { sia en dia, y } \\
\text { hora clara, }\end{array}$ \\
\hline $9 \mathrm{I}$ & & & & $\begin{array}{l}\text { car fort li nou } \\
\text { com se regua } \\
\text { ab leig temps e } \\
\text { no sen fa tant } \\
\text { bella nj tant } \\
\text { be. }\end{array}$ & & $\begin{array}{l}\text { que sis regan } \\
\text { en hora } \\
\text { escura, nos fan } \\
\text { tant bellas. }\end{array}$ \\
\hline
\end{tabular}




\begin{tabular}{|c|c|c|c|c|c|c|}
\hline $\begin{array}{l}\text { M(Madrid) } \\
\text { BNE IO2II }\end{array}$ & $\begin{array}{l}V \text { (Valencia) } \\
\text { BMSM 6437 }\end{array}$ & $\begin{array}{l}A \text { (Annapo- } \\
\text { lis) MS Gwara }\end{array}$ & $\begin{array}{l}P \text { (Paris) BnF } \\
\text { esp. 29I }\end{array}$ & $\begin{array}{l}B \text { (Barcelo- } \\
\text { na) BCB } 754\end{array}$ & $\begin{array}{l}N \text { (Naples) } \\
\text { Branc III AII }\end{array}$ & $\begin{array}{l}\text { Miquel } \\
\text { Agustí I6I7 }\end{array}$ \\
\hline $\begin{array}{l}\text { Quj quiere } \\
\text { aver simjente } \\
\text { de çebollas. } \\
\text { tome de las } \\
\text { mas bellas } \\
\text { çebollas que } \\
\text { pueda fallar } \\
\text { E plante las } \\
\text { mediado } \\
\text { Noujembre. } \\
\text { E en su } \\
\text { [fol. 2I3r] } \\
\text { tiempo fara } \\
\text { simjente. La } \\
\text { qual simjente } \\
\text { despues que } \\
\text { es sembrada } \\
\text { dura a sallir } \\
\text {.xxx. dias. } \\
92\end{array}$ & $\begin{array}{l}\text { Qui vol hauer } \\
\text { llauor de çebes } \\
\text { prenga deles } \\
\text { pus belles } \\
\text { que puga } \\
\text { trobar y plante } \\
\text { les mijant } \\
\text { nohembre } \\
\text { enson temps } \\
\text { fara llauor la } \\
\text { qual apres que } \\
\text { es sembrada } \\
\text { tarda a exir } \\
\text {.xxx. dies }\end{array}$ & & & $\begin{array}{l}\text { Qui vol hauer } \\
\text { dela lauor } \\
\text { planta deles } \\
\text { cebes grosses } \\
\text { deles pus } \\
\text { belles que } \\
\text { trops mijant } \\
\text { noembre e } \\
\text { faran lauor e } \\
\text { leix les hom } \\
\text { assahonar e } \\
\text { stoig les hom } \\
\text { tro al temps } \\
\text { que les deu } \\
\text { hom sembrar } \\
\text { e no hix pus es } \\
\text { sembrada tro } \\
\text { a xxx djes ans } \\
\text { sta dins terra } \\
\text { los djts xxx } \\
\text { djes }\end{array}$ & & $\begin{array}{l}\text { [fol. 26v] } \\
\text { Per tenir } \\
\text { bona llauor } \\
\text { quant seran } \\
\text { asahonades, } \\
\text { pendreu } \\
\text { de las mes } \\
\text { grossas las } \\
\text { que voldreu, y } \\
\text { las plantareu } \\
\text { en lo mes de } \\
\text { Nohembre, } \\
\text { estaran à exir } \\
\text { vint ò trenta } \\
\text { dias }^{16 z}\end{array}$ \\
\hline $\begin{array}{l}\text { çebolla } \\
\text { rredonda para } \\
\text { pastor siembra } \\
\text { hombre en } \\
\text { agosto en } \\
\text { luna vieja. E } \\
\text { trasplantase } \\
\text { en octubre o } \\
\text { en Noujem- } \\
\text { bre. } \\
93\end{array}$ & & & & $\begin{array}{l}\text { [5.I7] Ceba } \\
\text { redona aquella } \\
\text { que hom } \\
\text { menge tendra } \\
\text { sembra hom } \\
\text { en Agost ab } \\
\text { rauens e son } \\
\text { bones asopar }\end{array}$ & & \\
\hline
\end{tabular}

I67. Here Agustí I6Iz inserts (f. 26v) “y granaran, y quant sia asahonat lo estrujareu que sera per lo Ianer. [fol. 26v] Si voleu que las Cebas se seruen, y que nos grillen nis podrescan, fins en lo mes de Maig, ò de Iuny, procurau cullirles lo mes de Iuliol, ò de Agost, ò de Setembre quant estigan en saho, dia axut, y Lluna vella, que nos colpejan, despres les posareu en lo Sol, à axugar, que nos banyen, y les posareu dins de vna bota desfonsada de vn cap à sostres, posant à cada sostre cals viua, com si era sal, desta manera se saluaran com tinch dit". 


\begin{tabular}{|c|c|c|c|c|c|c|}
\hline $\begin{array}{l}\text { M(Madrid) } \\
\text { BNE IO2II }\end{array}$ & $\begin{array}{l}V \text { (Valencia) } \\
\text { BMSM 6437 }\end{array}$ & $\begin{array}{l}A \text { (Annapo- } \\
\text { lis) MS Gwara }\end{array}$ & $\begin{array}{l}P \text { (Paris) BnF } \\
\text { esp. 29I }\end{array}$ & $\begin{array}{l}B \text { (Barcelo- } \\
\text { na) BCB } 754\end{array}$ & $\begin{array}{l}N \text { (Naples) } \\
\text { Branc III AII }\end{array}$ & $\begin{array}{l}\text { Miquel } \\
\text { Agustí I6I7 }\end{array}$ \\
\hline $\begin{array}{l}\text { Calabaças } \\
\text { se siembran } \\
\text { de mediado } \\
\text { enero. fasta } \\
\text { mediado } \\
\text { febrero en } \\
\text { luna nueua } \\
\text { con mucho } \\
\text { estiercol. } \\
\text { medio palmo } \\
\text { en alto. }\end{array}$ & $\begin{array}{l}\text { Carabaçes se } \\
\text { sembren de } \\
\text { mijant giner } \\
\text { fins mijant } \\
\text { febrer en lluna } \\
\text { noua ab molts } \\
\text { fems mig palm } \\
\text { enalt }\end{array}$ & & & $\begin{array}{l}\text { [5.23] De } \\
\text { Carabaces. } \\
\text { Carabaces } \\
\text { sembra hom } \\
\text { mjant Giner } \\
\text { tro a mijant } \\
\text { ffebrer ço es } \\
\text { que planta } \\
\text { hom lo gra en } \\
\text { la Luna noua } \\
\text { e met hi hom } \\
\text { molt fems be } \\
\text { mig palm de } \\
\text { alt }\end{array}$ & & $\begin{array}{l}\text { [fol. } 29 r] \\
\text { Secrets de les } \\
\text { carabaces, } \mathbf{y} \\
\text { Cogombres } \\
\text { Les Carabaces } \\
\text { haueu de } \\
\text { sembrar en lo } \\
\text { mes de Febrer } \\
\text { apres la Lluna } \\
\text { haura fet lo } \\
\text { ple, }{ }^{168} \text { en bona } \\
\text { terra posant y } \\
\text { molt fems, fent } \\
\text { de quant en } \\
\text { quant vns clots } \\
\text { de fondo de } \\
\text { vn bon palm, } \\
\text { omplintlos de } \\
\text { fems ab poca } \\
\text { terra, }\end{array}$ \\
\hline $\begin{array}{l}\text { E de suso del } \\
\text { estiercol pone } \\
\text { hombre los } \\
\text { granos. } \\
95\end{array}$ & $\begin{array}{l}\text { y sobre los } \\
\text { fems posa hom } \\
\text { los grans }\end{array}$ & & & $\begin{array}{l}\text { e sobre los } \\
\text { fems mit los } \\
\text { grans }\end{array}$ & & $\begin{array}{l}\text { despres } \\
\text { posareu los } \\
\text { grans, ço es, } \\
\text { sinch ò sis per } \\
\text { lo entorn del } \\
\text { clot }\end{array}$ \\
\hline $\begin{array}{l}\text { E cubre } \\
\text { los hombre } \\
\text { con tierra } \\
\text { mezclada con } \\
\text { estiercol } \\
96\end{array}$ & $\begin{array}{l}\text { y cobrels ab } \\
\text { terra mesclada } \\
\text { ab fems }\end{array}$ & & & $\begin{array}{l}\text { ecobrels } \\
\text { hom ab vna } \\
\text { poqua de terra } \\
\text { mesclada ab } \\
\text { los fems }\end{array}$ & & $\begin{array}{l}\text { cobrintlos de } \\
\text { fems, y terra } \\
\text { mesclada, que } \\
\text { sols estigan } \\
\text { cuberts vn } \\
\text { traues de dit, }\end{array}$ \\
\hline 97 & & & & & & $\begin{array}{l}\text { [fol. 29r] } \\
\text { y abans de } \\
\text { sembrar los } \\
\text { fareu estar en } \\
\text { remull tres ò } \\
\text { quatre dias ab } \\
\text { aygua tibia, }\end{array}$ \\
\hline
\end{tabular}

I68. The "luna noua" prescribed by the other witnesses in this row is not the new moon in the modern sense, but rather, a waxing moon. If we accept that apres is here functioning as the preposition 'after' (and not the conjunction 'near'), then, inexplicably, Agustí's phrase "apres la Lluna haura fet lo ple" denotes just the opposite of the other witnesses, i.e., a waning gibbous moon, following after ("apres") the moon has reached its full phase. This contradiction is even clearer when this passage is compared with a similar phrase in the chapter on winter cabbages "se sembran en lo Iuny en Lluna vella, apres que haura fet lo ple" (Agustí i6iz: 23r), where there is no contradiction between lluna vella 'waning moon' and the phrase "apres que haura fet lo ple" (see row 5). 


\begin{tabular}{|c|c|c|c|c|c|c|}
\hline $\begin{array}{l}\text { M(Madrid) } \\
\text { BNE IO2II }\end{array}$ & $\begin{array}{l}V \text { (Valencia) } \\
\text { BMSM 6437 }\end{array}$ & $\begin{array}{l}A \text { (Annapo- } \\
\text { lis) MS Gwara }\end{array}$ & $\begin{array}{l}\text { P(Paris) BnF } \\
\text { esp. 29I }\end{array}$ & $\begin{array}{l}B \text { (Barcelo- } \\
\text { na) BCB } 754\end{array}$ & $\begin{array}{l}N \text { (Naples) } \\
\text { Branc III AII }\end{array}$ & $\begin{array}{l}\text { Miquel } \\
\text { Agustí I6I7 }\end{array}$ \\
\hline $\begin{array}{l}\text { en lugar do } \\
\text { toque bien el } \\
\text { sol [see also } \\
\text { Io9] }\end{array}$ & $\begin{array}{l}\text { en lloch hon } \\
\text { toque be lo sol } \\
\text { [see also rog] }\end{array}$ & & & $\begin{array}{l}\text { e han ops loch } \\
\text { hon toch lo sol } \\
\text { tots dies e noy } \\
\text { pusque toquar } \\
\text { gran vent }\end{array}$ & & $\begin{array}{l}\text { y mirau que } \\
\text { en lo lloch } \\
\text { ahont los } \\
\text { sembrareu, y } \\
\text { toc be lo Sol } \\
\text { tot lo dia, y } \\
\text { que noy pas } \\
\text { molt de vent, }\end{array}$ \\
\hline 99 & & & & $\begin{array}{l}\text { E si fahie gran } \\
\text { fret com deuen } \\
\text { exir cobrj les } \\
\text { hom ab draps } \\
o \text { ab stores } \\
\text { enguisa quel } \\
\text { fret noy mogue }\end{array}$ & & [see II4] \\
\hline $\begin{array}{l}\text { \& rregar } \\
\text { muchas vezes. } \\
\text { IOO }\end{array}$ & $\begin{array}{l}\text { y fan a regar } \\
\text { souint }\end{array}$ & & & $\begin{array}{l}\text { e fan areguar } \\
\text { de iij. en .iij. } \\
\text { Jorns e com } \\
\text { pus souin les } \\
\text { regue hom pus } \\
\text { tost se fan E } \\
\text { si laygua era } \\
\text { calenta del sol } \\
\text { hi valrja mes }\end{array}$ & & $\begin{array}{l}\text { regantles de } \\
\text { tres en tres } \\
\text { dias, }\end{array}$ \\
\hline IOI & & & & & & $\begin{array}{l}\text { y com anirant } \\
\text { crexent } \\
\text { anaulos cauant } \\
\text { la terra per lo } \\
\text { entorn, y se } \\
\text { fan millor: }\end{array}$ \\
\hline $\begin{array}{l}\text { [see Io8] } \\
\\
\text { IO2 } \\
\end{array}$ & [see ro8] & & & & & $\begin{array}{l}\text { les que voldreu } \\
\text { transplantar } \\
\text { las } \\
\text { transplantareu } \\
\text { en lo mes de } \\
\text { Abril, tambe } \\
\text { en la Lluna } \\
\text { noua al segon } \\
\text { quart ab molt } \\
\text { fems, y les } \\
\text { regareu axi } \\
\text { matex, }\end{array}$ \\
\hline IO3 & & & & & & $\begin{array}{l}\text { y si fa fret, } \\
\text { ò gelades } \\
\text { les cubrireu } \\
\text { ab draps, ò } \\
\text { estores, ò ab } \\
\text { los remeys } \\
\text { tenim dits (...) }\end{array}$ \\
\hline
\end{tabular}




\begin{tabular}{|c|c|c|c|c|c|c|}
\hline $\begin{array}{l}M \text { (Madrid) } \\
\text { BNE IO2II }\end{array}$ & $\begin{array}{l}V \text { (Valencia) } \\
\text { BMSM 6437 }\end{array}$ & $\begin{array}{l}A \text { (Annapo- } \\
\text { lis) MS Gwara }\end{array}$ & $\begin{array}{l}P \text { (Paris) BnF } \\
\text { esp. 29I }\end{array}$ & $\begin{array}{l}B \text { (Barcelo- } \\
\text { na) BCB } 754\end{array}$ & $\begin{array}{l}N \text { (Naples) } \\
\text { Branc III AII }\end{array}$ & $\begin{array}{l}\text { Miquel } \\
\text { Agustí I6I? }\end{array}$ \\
\hline $\begin{array}{l}\text { Empero es } \\
\text { nesçesario } \\
\text { quelos granos } \\
\text { sean bien } \\
\text { secos. E } \\
\text { despues } \\
\text { IO4 } \\
\end{array}$ & $\begin{array}{l}\text { Empero es } \\
\text { mester quels } \\
\text { grans sien ben } \\
\text { sechs, y apres }\end{array}$ & & & $\begin{array}{l}\text { Los grans } \\
\text { deles } \\
\text { carabaces }\end{array}$ & & \\
\hline 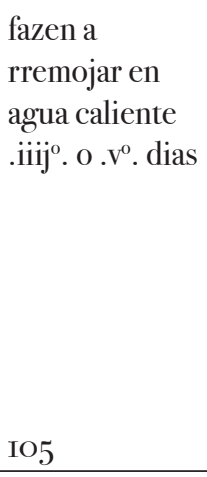 & $\begin{array}{l}\text { fan a remullar } \\
\text { en aygua } \\
\text { calenta.iiij. o } \\
\text {.v. dies }\end{array}$ & & & $\begin{array}{l}\text { fan aremullar } \\
\text { ab ayg[u]a } \\
\text { tebea qujs vol } \\
\text { e seran pus } \\
\text { tost exides de } \\
\text {.iiij. o v. djes } \\
\text { E com seran } \\
\text { remullades } \\
\text { plant les hom } \\
\text { en la manera } \\
\text { desus dite }\end{array}$ & & [see 97] \\
\hline $\begin{array}{l}\text { [see IO4] } \\
\\
\text { Io6 } \\
\end{array}$ & [see ro4] & & & $\begin{array}{l}\text { Ops es quels } \\
\text { grans deles } \\
\text { Carabaces } \\
\text { ans que } \\
\text { sien mesos } \\
\text { aremullar sien } \\
\text { ben sechs } \\
\end{array}$ & & \\
\hline $\mathrm{IO} 7$ & & & & $\begin{array}{l}\text { e sino eren } \\
\text { ben sechs... }{ }^{169}\end{array}$ & & \\
\hline $\begin{array}{l}\text { E deuen se } \\
\text { trasplantar } \\
\text { enel mes de } \\
\text { abril en luna } \\
\text { Nueua } \\
\text { Io8 }\end{array}$ & $\begin{array}{l}\text { e deuense } \\
\text { tresplantar en } \\
\text { lo mes de abril } \\
\text { en lluna noua }\end{array}$ & & & $\begin{array}{l}\text { Empero les } \\
\text { carabasses } \\
\text { nouelles fan } \\
\text { atresplantar } \\
\text { en lo mes de } \\
\text { Abril en la } \\
\text { Luna noua }{ }^{170}\end{array}$ & & [see IO2] \\
\hline $\begin{array}{l}\text { en lugar do } \\
\text { toque el sol } \\
\text { con mucho } \\
\text { estiercol. E } \\
\text { fazen a rregar } \\
\text { muchas vezes } \\
\text { Io9 }\end{array}$ & $\begin{array}{l}\text { e hon toque be } \\
\text { lo sol ab molts } \\
\text { fems y fan a } \\
\text { regar souint }\end{array}$ & & & & & \\
\hline
\end{tabular}

I69. Here $B$ inserts (I2Ir): "e sino eren ben sechs sequels al sol e puys remullals axi com demunt es djt. Eximple per sancta Agatha sembra ta carabaça si vols que be te fasa la qual festa es a .x. djes de ffebrer”.

I7O. Here $B$ inserts (I2Ir): "E planta les hom axj fa hom hun clot que hage be dos o tres palms o mes dample e de pregon hun palm e mig e fa li hom entorn lo clot orle de terra e puys en mig loch posa hom molt fems mesclat ab terra $\mathrm{e}$ fa li hom vn mont alt en mig del clot e plantey hom tres planters de carabaces e aço fa hom per ço quelo clot ample hom daygua al reguar de la mota de mig per tal que aygua no toch al vll dela carabaça car menys ne valrja e regueles hom de .iij. en .iij. djes de sesta ab calor tro que sien ben preses". 


\begin{tabular}{|c|c|c|c|c|c|c|}
\hline $\begin{array}{l}\text { M(Madrid) } \\
\text { BNE Io2II }\end{array}$ & $\begin{array}{l}V \text { (Valencia) } \\
\text { BMSM 6437 }\end{array}$ & $\begin{array}{l}A \text { (Annapo- } \\
\text { lis) MS Gwara }\end{array}$ & $\begin{array}{l}\text { P(Paris) BnF } \\
\text { esp. 29I }\end{array}$ & $\begin{array}{l}B \text { (Barcelo- } \\
\text { na) BCB } 754\end{array}$ & $\begin{array}{l}N \text { (Naples) } \\
\text { Branc III AII }\end{array}$ & $\begin{array}{l}\text { Miquel } \\
\text { Agustí I6I7 }\end{array}$ \\
\hline IIO & & & & $\begin{array}{l}\text { E si per } \\
\text { ventura fahia } \\
\text { gran fret cobre } \\
\text { les hom }\end{array}$ & & \\
\hline III & & & $\begin{array}{l}\text { [fol. 6rv] De } \\
\text { carabaçes } \\
\text { primeren- } \\
\text { ques. Si } \\
\text { vols hauer } \\
\text { carabaçes } \\
\text { primerenques } \\
\text { abans de sent } \\
\text { Johan de Juny } \\
\text { ajes bon fem } \\
\text { destable que } \\
\text { sia ben podrit } \\
\text { he solegat } \\
\text { com pose en } \\
\text { lo capitol del } \\
\text { fem e mesclat } \\
\text { en bona terra } \\
\text { graça alli sien } \\
\text { sembrades les } \\
\text { carabases lo } \\
\text { jorn de sent } \\
\text { Valentj quj } \\
\text { és a .xiiij. de } \\
\text { febrer. E sien } \\
\text { plantades en } \\
\text { loch de sol } \\
\text { per mesura. e } \\
\text { sien regades } \\
\text { soujnt. e auras } \\
\text { carabaçes } \\
\text { primerenques. } \\
\text { Ha volerles } \\
\text { hun poch pus } \\
\text { tardanes se } \\
\text { volen sembrar } \\
\text { en lo mes de } \\
\text { març com } \\
\text { aquell mes sia } \\
\text { la mare de les } \\
\text { semençes }\end{array}$ & $\begin{array}{l}\text { [5.24] De } \\
\text { Carabaces } \\
\text { primaren- } \\
\text { ques. Si } \\
\text { vols hauer } \\
\text { carabaces } \\
\text { primarenques } \\
\text { sembrales } \\
\text { segons que } \\
\text { en lo Capitol } \\
\text { desus es dit } \\
\text { e com seran } \\
\text { exides no les } \\
\text { regues ab } \\
\text { aygua mas } \\
\text { regua les ab } \\
\text { leyt de vaques } \\
\text { o de ouelles } \\
\text { o de cabres } \\
\text { e hauras } \\
\text { carabaces molt } \\
\text { primarenques. }\end{array}$ & & $\begin{array}{l}\text { [fol. 29r] } \\
\text { Si voleu les } \\
\text { Carabaças y } \\
\text { Cogombres } \\
\text { que sian } \\
\text { primarencas, } \\
\text { posareu en } \\
\text { testos dolents, } \\
\text { ò cofins, terra } \\
\text { molt bona } \\
\text { passada ab } \\
\text { vn garbell, y } \\
\text { mesclareu ab } \\
\text { ella fems que } \\
\text { sia grasseta, } \\
\text { que casi se } \\
\text { puga pastar, } \\
\text { y abans } \\
\text { del temps } \\
\text { acostumat, } \\
\text { y sembrareu } \\
\text { dels grans de } \\
\text { les Carabaças, } \\
\text { y Cogombres: } \\
\text { quant sera axit } \\
\text { lo sol, y fara } \\
\text { lo dia bo, ò } \\
\text { voldra ploure, } \\
\text { traureu los } \\
\text { testos, ò } \\
\text { cofins defora, } \\
\text { y quant lo Sol } \\
\text { se pondra } \\
\text { los tornareu } \\
\text { á posar } \\
\text { dins casa, ò } \\
\text { en cubert, } \\
\text { fent aço } \\
\text { continuament, } \\
\text { y regantles } \\
\text { quant ho } \\
\text { hauran } \\
\text { menester. } \\
\text { Quant } \\
\text { empero seran } \\
\text { passades las } \\
\text { geladas y frets } \\
\text { perfetament, }\end{array}$ \\
\hline
\end{tabular}




\begin{tabular}{|c|c|c|c|c|c|c|}
\hline $\begin{array}{l}M \text { (Madrid) } \\
\text { BNE IO2II }\end{array}$ & $\begin{array}{l}V \text { (Valencia) } \\
\text { BMSM 6437 }\end{array}$ & $\begin{array}{l}A \text { (Annapo- } \\
\text { lis) MS Gwara }\end{array}$ & $\begin{array}{l}P \text { (Paris) BnF } \\
\text { esp. 29I }\end{array}$ & $\begin{array}{l}B \text { (Barcelo- } \\
\text { na) BCB } 754\end{array}$ & $\begin{array}{l}N \text { (Naples) } \\
\text { Branc III AII }\end{array}$ & $\begin{array}{l}\text { Miquel } \\
\text { Agustí I6I7 }\end{array}$ \\
\hline III & & & & & & $\begin{array}{l}\text { (cont.) } \\
\text { pendreu los } \\
\text { cofins, y tests, } \\
\text { y los posareu } \\
\text { debax de terra } \\
\text { ben cultiuada } \\
\text { y grassa, de } \\
\text { tal manera } \\
\text { que la terra } \\
\text { vinga ygual, } \\
\text { y raza ab los } \\
\text { tests, y tindreu } \\
\text { los demes } \\
\text { cuydado que } \\
\text { se acostuma } \\
\text { ab ellas, y los } \\
\text { lleuareu los } \\
\text { caps dels [fol. } \\
\text { 29v] brots, } \\
\text { de aquesta } \\
\text { manera vos } \\
\text { donaran prest } \\
\text { fruyt. (...) r.7 }\end{array}$ \\
\hline
\end{tabular}

I7I. Agustí I626 mirrors the Catalan version here. In both texts, two paragraphs follow without marginal attributions, so these may be original to Agustí and not to the Memòria, especially considering that they do not appear at the outset of the chapter, where he usually presents Memòria material. The first paragraph is on how to create designs on the surface of calabash and cucumbers as they grow, a practice that can be found in Ibn Wafid (Millás Vallicrosa I943: 32I) and the second is on forcing a calabash to grow inside a tube-shaped reed, resulting in an extraordinarily long specimen. Other paragraphs attributed to Mizaldo and Quintiliano in Agustí I6I7 close out the chapter in both texts. 


\begin{tabular}{|c|c|c|c|c|c|c|}
\hline $\begin{array}{l}\text { M(Madrid) } \\
\text { BNE IO2II }\end{array}$ & $\begin{array}{l}V \text { (Valencia) } \\
\text { BMSM 6437 }\end{array}$ & $\begin{array}{l}A \text { (Annapo- } \\
\text { lis) MS Gwara }\end{array}$ & $\begin{array}{l}P \text { (Paris) BnF } \\
\text { esp. 29I }\end{array}$ & $\begin{array}{l}B \text { (Barcelo- } \\
\text { na) BCB } 754\end{array}$ & $\begin{array}{l}N \text { (Naples) } \\
\text { Branc III AII }\end{array}$ & $\begin{array}{l}\text { Miquel } \\
\text { Agustí I6I? }\end{array}$ \\
\hline $\begin{array}{l}\text { Cogombros } \\
\text { Melones } \\
\text { Albudeques } \\
\text { Alberginjes } \\
\text { siembra } \\
\text { hombre en } \\
\text { luna nueua } \\
\text { de febrero } \\
\text { o de março } \\
\text { con mucho } \\
\text { estiercol. Asy } \\
\text { como Calaba- } \\
\text { ças. E quieren } \\
\text { estar poco } \\
\text { cubiertas. } \\
\text { fazen a rregar } \\
\text { de tres en tres } \\
\text { dias. }\end{array}$ & $\begin{array}{l}\text { Cogombros } \\
\text { Melons } \\
\text { Albudeques } \\
\text { Albarginjes } \\
\text { Sembra hom } \\
\text { en luna noua } \\
\text { de febrer o de } \\
\text { març ab molts } \\
\text { fems axi com } \\
\text { les carabaçes } \\
\text { y volen esser } \\
\text { poch cuberts } \\
\text { fan a regar de } \\
\text {.iij. en .iij. dies }\end{array}$ & & & $\begin{array}{l}\text { [5.25] De } \\
\text { melons } \\
\text { albudeques } \\
\text { cindrjes } \\
\text { cogombres \& } \\
\text { alberginjes. } \\
\text { Cogombres } \\
\text { melons } \\
\text { cindrjes } \\
\text { albudeques } \\
\text { e alberginjes } \\
\text { sembra hom } \\
\text { mijant ffebrer } \\
\text { e per tot lo } \\
\text { dit mes ab } \\
\text { luna noua e } \\
\text { ab molts fems } \\
\text { be [fol. I22r] } \\
\text { mig palm dalt } \\
\text { o mes axi com } \\
\text { les carabaces e } \\
\text { no fan a cobrir } \\
\text { guayre mas } \\
\text { tansolament } \\
\text { quelos grans } \\
\text { sien cuberts } \\
\text { de terra } \\
\text { mesclada ab } \\
\text { fems E volen } \\
\text { se reguar } \\
\text { souin de iij. en } \\
\text { iij. dies } \\
\end{array}$ & $\begin{array}{l}\text { [54r] Melons. } \\
\text { Cogombres. } \\
\text { albudeques e } \\
\text { alberginjes. } \\
\text { Primo los } \\
\text { Melons } \\
\text { albudeques } \\
\text { mijant Mars e } \\
\text { los cogombres } \\
\text { alberginjes } \\
\text { mijant ffebrer } \\
\text { o per tot lo } \\
\text { mes en luna } \\
\text { noua totes e } \\
\text { totes axi } \\
\text { mateix com } \\
\text { les carabasses } \\
\text { e no fan a } \\
\text { cobrjr massa } \\
\text { mas trant [sic] } \\
\text { solament quels } \\
\text { grans sien } \\
\text { cuberts de } \\
\text { terra mesclada } \\
\text { ab fems e } \\
\text { deuen se regar } \\
\text { de tres en tres } \\
\text { dies }\end{array}$ & \begin{tabular}{|l} 
[fol. 29v] \\
Secrets de \\
Melons. Los \\
Melons se han \\
de sembrar \\
en lo mes de \\
Mars en Lluna \\
vella com los \\
Carabasses, y \\
ab la matexa \\
terra y \\
diligencia que \\
tenim dit de \\
les Carabaçes,
\end{tabular} \\
\hline \multicolumn{7}{|r|}{$\begin{array}{l}\text { In se } \\
\text { brar } \\
\text { loch: } \\
\text { en } \\
\text { tar, } \\
\text { la } \\
\text { terra, }\end{array}$} \\
\hline $\begin{array}{l}\text { E que esten en } \\
\text { lugar do toque } \\
\text { bien el sol. E } \\
\text { tras-plantan } \\
\text { se en abril } \\
\text { con mu-cho } \\
\text { estiercol. }\end{array}$ & $\begin{array}{l}\text { y quels toque } \\
\text { be lo sol y } \\
\text { tresplantense } \\
\text { en abril ab } \\
\text { molts fems }\end{array}$ & & & $\begin{array}{l}\text { E volen que } \\
\text { lla hon son } \\
\text { sembrats los } \\
\text { grans quels } \\
\text { hi toch lo sol } \\
\text { tot lo dia o la } \\
\text { maior partida } \\
\text { e volen se } \\
\text { reguar de.iij. } \\
\text { en .iij. Jorns }\end{array}$ & $\begin{array}{l}\text { e sien plantats } \\
\text { en loch hon lo } \\
\text { sol toch tot lo } \\
\text { dia o la maior } \\
\text { partida e } \\
\text { deuen se regar } \\
\text { axicom dit es }\end{array}$ & $\begin{array}{l}\text { se han de fer } \\
\text { en part en la } \\
\text { qual lo Sol los } \\
\text { toque tot lo } \\
\text { dia. Volen se } \\
\text { regar sempre } \\
\text { sia menester, }\end{array}$ \\
\hline
\end{tabular}




\begin{tabular}{|c|c|c|c|c|c|c|}
\hline $\begin{array}{l}\text { M(Madrid) } \\
\text { BNE IO2II }\end{array}$ & $\begin{array}{l}\text { V(Valencia) } \\
\text { BMSM 6437 }\end{array}$ & $\begin{array}{l}\text { A (Annapo- } \\
\text { lis) MS Gwara }\end{array}$ & $\begin{array}{l}P(\text { Paris }) \mathrm{BnF} \\
\text { esp. 29I }\end{array}$ & $\begin{array}{l}B \text { (Barcelo- } \\
\text { na) BCB } 754\end{array}$ & $\begin{array}{l}N \text { (Naples) } \\
\text { Branc III AII }\end{array}$ & $\begin{array}{l}\text { Miquel } \\
\text { Agustí I6I? }\end{array}$ \\
\hline $\begin{array}{l}\text { Empero } \\
\text { quando los } \\
\text { cogom-bros } \\
\text { \& melones } \\
\text { comjençan a } \\
\text { madurar. non } \\
\text { se qujeren } \\
\text { rregar. E } \\
\text { puede los } \\
\text { hombre } \\
\text { trasplantar } \\
\text { [sic] en lugar } \\
\text { do no los cale } \\
\text { trasplantar } \\
\text { II5 }\end{array}$ & $\begin{array}{l}\text { empero quant } \\
\text { los cogombros } \\
\text { y melons } \\
\text { començen a } \\
\text { madurar nos } \\
\text { volen regar } \\
\text { e podense } \\
\text { sembrar en } \\
\text { lloch hon nols } \\
\text { cal tresplantar }\end{array}$ & & & $\begin{array}{l}\text { Exceptat los } \\
\text { melons e les } \\
\text { albudeques } \\
\text { e les cindrjes } \\
\text { Si donchs no } \\
\text { vehia hom } \\
\text { que mester ho } \\
\text { haguessen E } \\
\text { pot los hom } \\
\text { sembrar en } \\
\text { loch que no les } \\
\text { cal tresplantar } \\
\text { si hom nos vol }\end{array}$ & $\begin{array}{l}\text { exceptat los } \\
\text { melons e les } \\
\text { albudeques } \\
\text { si donchs no } \\
\text { veyen que } \\
\text { mester ho } \\
\text { haguessen e } \\
\text { pot los hom } \\
\text { sembrar en } \\
\text { loch que } \\
\text { noles cal } \\
\text { transplantar } \\
\text { sinos vol hom. }\end{array}$ & $\begin{array}{l}\text { acceptat quant } \\
\text { volen madurar: } \\
\text { per que sian } \\
\text { bons los } \\
\text { Melons, non } \\
\text { haueu de } \\
\text { dexar sino à } \\
\text { cada mata dos } \\
\text { ò tres, }\end{array}$ \\
\hline пI6 & & & & $\begin{array}{l}\text { E si per } \\
\text { ventura fahia } \\
\text { fret abrich les } \\
\text { hom axi com } \\
\text { les carabaces }\end{array}$ & $\begin{array}{l}\text { E si faya fret } \\
\text { pot les hom } \\
\text { cobrir segons } \\
\text { que dit es }\end{array}$ & \\
\hline II 7 & & & & $\begin{array}{l}\text { La lauor dels } \\
\text { melons e } \\
\text { cindrjes e de } \\
\text { alberginjes de } \\
\text { cogombres e } \\
\text { de albudeques } \\
\text { ans que hom } \\
\text { les sembre } \\
\text { deu esser } \\
\text { remullada ab } \\
\text { aygua ij. o .iij. } \\
\text { djes }\end{array}$ & $\begin{array}{l}\text { totes aquestes } \\
\text { lauors ans } \\
\text { que hom } \\
\text { les sembre } \\
\text { deuen esser } \\
\text { remullades } \\
\text { dos o tres dies } \\
\text { abans. }\end{array}$ & $\begin{array}{l}\text { y abans de } \\
\text { sembrar haueu } \\
\text { de posar los } \\
\text { grans en } \\
\text { ramull ab } \\
\text { algun licor } \\
\text { dos ò tres } \\
\text { dias, apres } \\
\text { sembrarlos. } \\
(. . .)\end{array}$ \\
\hline II8 & & & & $\begin{array}{l}\text { Les } \\
\text { albudeques } \\
\text { cogombres } \\
\text { melons } \\
\text { cindrjes e } \\
\text { alberginjes } \\
\text { deuen esser } \\
\text { sembrades per } \\
\text { tot ffebrer }\end{array}$ & & \\
\hline II9 & & & & e ha spay... ${ }^{17^{2}}$ & & \\
\hline
\end{tabular}

I72. $B$ adds (f. I22r): "e ha spay deles djtes dues lauors ales altres dues .xx. o .xxx. jorns specialment lo millor temps de sembrar albudeques o melons o cindrjes es entorn la ffesta de sancta marja de Març en la manera que dit es”. 


\begin{tabular}{|c|c|c|c|c|c|c|}
\hline $\begin{array}{l}\text { M(Madrid) } \\
\text { BNE IO2II }\end{array}$ & $\begin{array}{l}\text { V(Valencia) } \\
\text { BMSM 6437 }\end{array}$ & $\begin{array}{l}A \text { (Annapo- } \\
\text { lis) MS Gwara }\end{array}$ & $\begin{array}{l}P \text { (Paris) BnF } \\
\text { esp. 29I }\end{array}$ & $\begin{array}{l}\text { B (Barcelo- } \\
\text { na) BCB } 754\end{array}$ & $\begin{array}{l}N \text { (Naples) } \\
\text { Branc III AII }\end{array}$ & $\begin{array}{l}\text { Miquel } \\
\text { Agustí I6I7 }\end{array}$ \\
\hline $\begin{array}{l}\text { Espinacas [sic] } \\
\text { faze a ssem- } \\
\text { brar en julio } \\
\text { en la luna vieja } \\
\text { en tierra fonda } \\
\text { cauada menos } \\
\text { de estiercol E } \\
\text { que se rieguen } \\
\text { muchas vezes } \\
\text { \& no conviene } \\
\text { a trasplantar }\end{array}$ & $\begin{array}{l}\text { [fol. 95v23] } \\
\text { Pastanagues } \\
\text { fan a sembrar } \\
\text { en Joliol en } \\
\text { lluna vella } \\
\text { enterra fondo } \\
\text { cauada sens } \\
\text { fems mas volen } \\
\text { ques reguen } \\
\text { souint y noles } \\
\text { cal tresplantar }\end{array}$ & & & $\begin{array}{l}\text { [5.19] De } \\
\text { Pastanagues. } \\
\text { Pastanagues } \\
\text { sembra hom en } \\
\text { Juliol en Luna } \\
\text { vella en terra } \\
\text { ben cauada } \\
\text { pregon e ben } \\
\text { guaretada no } \\
\text { volen fems mas } \\
\text { volen se reguar } \\
\text { souin e nos } \\
\text { tresplanten }\end{array}$ & & $\begin{array}{l}\text { [fol. 27v] } \\
\text { Secret de } \\
\text { Pastenagas. } \\
\text { [fol. 28r] Les } \\
\text { Pastenagues se } \\
\text { sembran en lo } \\
\text { mes de Iuliol } \\
\text { en la Lluna } \\
\text { vella, apres que } \\
\text { ha fet lo ple en } \\
\text { lo matex quart, } \\
\text { vol la terra ben } \\
\text { fangada, y ben } \\
\text { femada, }{ }^{173}\end{array}$ \\
\hline $\begin{array}{l}\text { Los nabos se } \\
\text { siembran en } \\
\text { julio en la luna } \\
\text { vieja. }\end{array}$ & $\begin{array}{l}\text { Los naps se } \\
\text { sembren en } \\
\text { joliol en lluna } \\
\text { vella }\end{array}$ & & $\begin{array}{l}\text { [fol. 6Iv] De } \\
\text { sembrar } \\
\text { naps. Si vols } \\
\text { sembrar naps } \\
\text { sembrarlos } \\
\text { has .viiii. dies } \\
\text { abans de senta } \\
\text { Justa e Rufina } \\
\text { quj es a .xvij. } \\
\text { de juljol o .viiij. } \\
\text { dies apres, que } \\
\text { diu lo exemple } \\
\text { del antich: a } \\
\text { santa Justa e } \\
\text { Rufina planta } \\
\text { pastanages } \\
\text { e napina, } \\
\text { quj son dits } \\
\text { naps, empero } \\
\text { guarda que } \\
\text { sia bona terra } \\
\text { barbeytada, } \\
\text { femada e } \\
\text { cauada fondo, } \\
\text { e auras bons } \\
\text { naps. }\end{array}$ & \begin{tabular}{|l|} 
[5.20] De \\
Naps. Naps \\
sembra hom en \\
Juliol en Luna \\
vella axi com \\
les pastanagues \\
e sie ala \\
entrada del \\
mes de Juliol \\
per ço com mes \\
val que sien \\
prjmarenchs \\
que tardans \\
e aço se \\
enten de tota \\
ortaliça que \\
mes val que sia \\
primarencha \\
que tardana E \\
diu leximplj a \\
sancta iusta e \\
Rufina sembra \\
la tua nabina \\
la qual festa \\
es .vij. dies ala \\
desexida de \\
Juliol
\end{tabular} & & $\begin{array}{l}\text { [fol. 28r] Los } \\
\text { Naps se han } \\
\text { de sembrar } \\
\text { en lo mes de } \\
\text { Iuliol en la } \\
\text { Lluna vella, en } \\
\text { lo quart ha fet } \\
\text { lo ple, y seran } \\
\text { primarenchs: } \\
\text { perque tota } \\
\text { la ortalisa } \\
\text { primarenca } \\
\text { val mes que la } \\
\text { tardana, diu } \\
\text { lo prouerbi, } \\
\text { que lo bon } \\
\text { Nap, per Sanct } \\
\text { Iaume ha de } \\
\text { ser nat. Tambe } \\
\text { ne podeu fer la } \\
\text { Lluna abans y } \\
\text { apres. }{ }^{174}\end{array}$ \\
\hline
\end{tabular}

I73. Here Agustí I6r7 inserts (f. 27v): “y nos volen sembrar molt espeses: perque se pugan fer ben grossas y belles, y estas seran bones en la Quaresma, tambe ne podeu sembrar en la Primauera, pero son millors las de la tardor, si voleu que la rael sia bella y grossa, conue que los aneu lleuant las fulles per aclarirles (...)”.

I74. Here Agustí i6I7 continues (f. 28r): "Lo Nap vol la terra ben fangada, y nouament moguda, y la llauor no ha de ser de mes de tres anys, que si es mes vella no produex sino Cols, Axi quant los sembrareu, procurareu de sembrarlos ab terra prima, mesclada ab lo gra: perque nos sembrian [sic] massa espeços. Si à cas, son massa espessos, los aueu de aclarir: Per sembrarlos, haueu de esperar que la terra sia estada regada primer, ò del cel, ò manualment: perque seran millors, y no los sembreu en lloch dehombra: perque la hombra los es molt contraria, sino es que la terra sia bona y fertil". 


\begin{tabular}{|c|c|c|c|c|c|c|}
\hline $\begin{array}{l}M \text { (Madrid) } \\
\text { BNE IO2II }\end{array}$ & $\begin{array}{l}\text { V(Valencia) } \\
\text { BMSM 6437 }\end{array}$ & $\begin{array}{l}A \text { (Annapo- } \\
\text { lis) MS Gwara }\end{array}$ & $\begin{array}{l}P \text { (Paris) BnF } \\
\text { esp. 29I }\end{array}$ & $\begin{array}{l}\text { B (Barcelo- } \\
\text { na) BCB } 754\end{array}$ & $\begin{array}{l}N \text { (Naples) } \\
\text { Branc III AII }\end{array}$ & $\begin{array}{l}\text { Miquel } \\
\text { Agustí I6I7 }\end{array}$ \\
\hline $\mathrm{I} 22$ & & & Alguns... ${ }^{175}$ & & & \\
\hline I23 & & & $\begin{array}{l}{[\text { [fol. 62r] }} \\
\text { De plantar } \\
\text { chereujes. } \\
\text { Quj vol plantar } \\
\text { chereujes } \\
\text { planteles en } \\
\text { luna crexent } \\
\text { que sia girada } \\
\text { de .viij. dies en } \\
\text { lo mes de jener, } \\
\text { o de febrer e la } \\
\text { lauor sia a mjga } \\
\text { cama, e que } \\
\text { aja en la terra } \\
\text { bona saho e per } \\
\text { auant en març } \\
\text { regar les has } \\
\text { mas volen terra } \\
\text { arenossa e molt } \\
\text { femada }{ }^{16}\end{array}$ & \begin{tabular}{|l|} 
[fol. I2IV] \\
[5.2r] De \\
xereujes. \\
Xereuies se \\
sembren en la \\
Luna vella de \\
Giner e deuen \\
se sembrar en \\
terra freda quels \\
fems sien be \\
podrits e deuen \\
se sembrar \\
clares per ço \\
que millor se \\
façen Jtem si tu \\
has dels grans \\
deles xarouies \\
que son rahils \\
de les xerouies e \\
si es massa gros \\
parteix lo en \\
algunes parts e \\
cascuna part mjt \\
la deuall terra \\
sol que tinga \\
dos dits de terra \\
desus e hauras \\
deles xereuies e \\
volen se fer en \\
loch fret e que \\
nols do massa \\
lo sol
\end{tabular} & & $\begin{array}{l}\text { [fol. 28r] Secret } \\
\text { de Xaravilles. } \\
\text { Sembrarev en } \\
\text { lo mes de Mars } \\
\text { en la Lluna } \\
\text { vella, apres } \\
\text { ha fet lo ple, } \\
\text { les Xarauilles } \\
\text { volen la terra } \\
\text { que sia molt } \\
\text { ben cauada, y } \\
\text { femada, tambe } \\
\text { ne podreu } \\
\text { sembrar tots los } \\
\text { mesos del any, } \\
\text { empero las del } \\
\text { mes de Mars } \\
\text { son las millors, } \\
\text { y de mes virtut, } \\
\text { y estan tot lo } \\
\text { any en la terra. }\end{array}$ \\
\hline 124 & & & & \begin{tabular}{|l|}
{$\left[\begin{array}{l}5.22] \\
\text { xufes. }{ }^{1} 77\end{array}\right.$} \\
\end{tabular} & & \\
\hline & & & & \begin{tabular}{|l|} 
[5.26] De \\
sembrar \\
Iuhiuert ${ }^{17^{8}}$
\end{tabular} & & \\
\hline
\end{tabular}

I75. Here $P$ inserts (f. 6rv) "Alguns los sembren en la terra hon han arenquats alls e sebes que si fan molt bons e ben saborosos e groços e [fol. 62r] no són corquats. Axj matex se planten os sembren les pastanagues”.

I76. Here $P$ inserts this anomolous chapter (f. 62r): "De donar color e sabor. Si vols donar color e sabor a qual se hulla fruyt pendras vna barrina e foradaras larbre en quatre parts en tant que la barrinadura li toque al cor. E puys aquells forats sien omplits de safra destemprat ab oli comu e maçis e girofle molt e puys sien tapats ab lenyam de fraig e tot arbre quj prodoyra fruyt quey sia aço aura sabor marauellossa".

I77. Here (f. I2Iv) $B$ inserts a chapter on nutsedge: "Xufes fan asembrar en maig deuen se collir en Agost deuen esser reguades en la hora quen hagen mester Jtem volen esser sembrades en bona terra car com en mjllor terra seran sembrades mjllors seran".

I78. Here $B$ inserts a chapter on parsley: "Si sembres lauor de juhiuert en lo mes de Març no spiguara tro en lo segon any". The chapter on parsley in Miquel Agustí r6r7 "Secret per fer que lo iulivert fassa las fullas molt amples, y crespades, y se fassa molt alt que causara admiracio" (25r) is taken from authors unrelated to the Memòria tradition (Florentino, Porta, Esteua). 
In the following table we present the chapters relating to non-horticultural topics that the copyists of $M, V$, and $N^{\mathrm{r} 79}$ included in their compilations. In these three witnesses the non-horticultural material is presented in close proximity to the Memória chapters on vegetable crops, appearing in $N$ immediately following them. Witnesses $M$, $V$, and $N$ have for this reason served as our guide in determining which non-horticultural material may have been traditionally associated with the Memòria, and consequently text from $P$ and $B$ is included only when it corresponds to these three witnesses $(M, V$, and $N)$. This procedure is further justified by the fact that the compilers of $P$ and $B$ present non-horticultural material in clearly separate and explicitly delineated sections, as if for them the separate cohesion of the horticultural chapters were an obvious fact. ${ }^{180}$

The purpose of this table is to allow the reader to observe the textual correspondences - some close, others rather distant - on topics such as viticulture, arboriculture and cereal and legume cultivation as they parallel each other across the five witnesses. It should be carefully noted, however, that there is no uniform order of presentation of these chapters in our corpus, except that $M$ and $V$, as usual, follow each other. In the manuscripts $P$ and $B$ these chapters and passages are scattered about in various sections of a separate work on agriculture, the Libre de plantar vinyes e arbres (Luna-Batlle 2OII). Therefore, the folio indications given below serve to highlight the discrepancies among the witnesses regarding the order of the chapters treated. It is hoped that as new versions of the Memòria are discovered, this table will contribute toward determining the relationship between the Memoria tradition and the non-horticultural material that often accompanies it. At present, the preponderance of evidence available suggests that the non-horticultural material derives from other sources (see Introduction) and that the Memòria de les maneres de les llaurons constitutes a treatise that, at its genesis, treated exclusively horticultural concerns.

I79. It will be recalled that $A$ (MS Gwara) has yet to be published and so is omitted from the table. Miquel Agustí I6I7 is likewise omitted, since its treatment of non-horticultural material appears in every respect to be independent of that found in $M, V, P, B$ and $N$. Two chapters from $P$ on beans and peas (fesols, pesols) are likewise excluded (see note $\mathrm{I}_{52}^{2}$ ).

I80. In $P$ these sections bear headings such as "Del libre terç paladi" (42V) and "Del libre quart paladi” (5 5 v); in $B$, even more explicitly, "Libre quart o quarta part en lo qual és tractat del cultivament de la terra e sembrar forment, ordi e altre blats grossos e menuts, e legums segons se segueix” (Luna-Batlle 2OII: 5). 


\begin{tabular}{|c|c|c|c|c|}
\hline $\begin{array}{l}M \text { (Madrid) } \\
\text { BNE IO2II }\end{array}$ & $\begin{array}{l}V \text { (Valencia) } \\
\text { BMSM 6437 }\end{array}$ & $\begin{array}{l}P \text { (Paris) } \\
\text { BnF esp. 29I }\end{array}$ & $\begin{array}{l}\text { B (Barcelona) } \\
\text { BCB 754 } \\
\end{array}$ & $\begin{array}{l}N \text { (Naples) } \\
\text { Branc III AII } \\
\end{array}$ \\
\hline I26 & & & $\begin{array}{l}\text { [fol. IIOv] [r.8] De } \\
\text { podar vinya. } \\
\text { Podar deu hom les } \\
\text { vinyes en dos mesos } \\
\text { del any ço es en lo } \\
\text { mes de dehembre e } \\
\text { en lo mes de Janer } \\
\text { mas mes val en lo mes } \\
\text { de dehembre per ço } \\
\text { com los ceps podats } \\
\text { de dehembre fan los } \\
\text { rahims pus grossos e } \\
\text { les sarments [fol. IIIr] } \\
\text { broten abans e abans } \\
\text { maduren Jtem que en } \\
\text { lo gra no haura sino } \\
\text { hun pinyol o dos } \\
\text { La podaho del mes de } \\
\text { Janer fa molts rahims } \\
\text { mas fals menors e ab } \\
\text { molts pinyols }\end{array}$ & $\begin{array}{l}\text { [fol. } 56 \text { r] Del podar } \\
\text { deles sarments. Del } \\
\text { podar deles sarments } \\
\text { te dich. si tu podes } \\
\text { la sarment trob tost } \\
\text { tu hauras moltes } \\
\text { sarments e si les } \\
\text { podes tard tu hauras } \\
\text { fruyt e apres bones } \\
\text { venemes. poda pus } \\
\text { estretament e apres } \\
\text { auols pus largament. } \\
\text { En Cathalunya poden } \\
\text { les vjnyes de deembre } \\
\text { de de Janer. Si poden } \\
\text { de deembre seran los } \\
\text { rayms pus grossos e } \\
\text { abans maduren e lo } \\
\text { gra no haura cor e } \\
\text { sino .j. pinyol o dos. } \\
\text { e si podes de Janer } \\
\text { hauras mes rayms mas } \\
\text { seran menuts e ab mes } \\
\text { pinyols o grans. }\end{array}$ \\
\hline I27 & & & $\begin{array}{l}\text { [fol. IIIr] Tot podar se } \\
\text { deu fer en la luna vella } \\
\text { E deu se hom gordar } \\
\text { que no pot hom en Lo } \\
\text { Jorn que es plena Car } \\
\text { lo ple dela Luna no val } \\
\text { ales plantes si hom les } \\
\text { tocha ans los nou Mas } \\
\text { pessat aquell dia es bo } \\
\text { lo podar tota hora e } \\
\text { com pus prop es dela } \\
\text { plena val mes lo podar }\end{array}$ & $\begin{array}{l}\text { E tota via se poden } \\
\text { en luna vella mas } \\
\text { no massa vella, mas } \\
\text { passada la luna plena } \\
\text { al terç o quart jorn. } \\
\text { Mas no podets james } \\
\text { en lo dia que sera } \\
\text { plena mas passat } \\
\text { aquell die es bo de } \\
\text { podar tota hora. }\end{array}$ \\
\hline I28 & & & $\begin{array}{l}\text { Empero les vinyes } \\
\text { velles deuen esser } \\
\text { podades a cap de } \\
\text { dos o de tres anys } \\
\text { en la Luna noua per } \\
\text { renouellar empero } \\
\text { tota hora haia la Luna } \\
\text { mes de .vij. Jorns }\end{array}$ & $\begin{array}{l}\text { Empero les vjnyes } \\
\text { velles deuen esser } \\
\text { podades a cap de dos } \\
\text { o tres anys en la luna } \\
\text { noua per renouellar e } \\
\text { que haia la luna mes } \\
\text { de .viij. jorns. }\end{array}$ \\
\hline
\end{tabular}




\begin{tabular}{|c|c|c|c|c|}
\hline $\begin{array}{l}\text { M(Madrid) } \\
\text { BNE IO2II } \\
\end{array}$ & $\begin{array}{l}V \text { (Valencia) } \\
\text { BMSM 6437 }\end{array}$ & $\begin{array}{l}P \text { (Paris) } \\
\text { BnF esp. 29I }\end{array}$ & $\begin{array}{l}B \text { (Barcelona) } \\
\text { BCB } 754\end{array}$ & $\begin{array}{l}N \text { (Naples) } \\
\text { Branc III AII }\end{array}$ \\
\hline $\begin{array}{l}\text { [fol. 2I3v] Podar de } \\
\text { luna vieja de enero } \\
\text { sson las vuas mas } \\
\text { gruessas \& con } \\
\text { menos vrujo. Podar en } \\
\text { febrero en luna vieja } \\
\text { faze muchas vuas mas } \\
\text { son menudas E con } \\
\text { menos vrujo. } \\
\text { I29 }\end{array}$ & $\begin{array}{l}\text { [fol. 95v32] Podar de } \\
\text { luna vella de giner } \\
\text { son los rahims pus } \\
\text { grossos y ab menys } \\
\text { vinaça. Podar en } \\
\text { febrer en lluna vella } \\
\text { fan molts rahims mas } \\
\text { son menuts. }\end{array}$ & & $\begin{array}{l}\text { [fol. IIIr] La podaho } \\
\text { dela Luna vella fa } \\
\text { sarments e rahims } \\
\text { grossos e bells Ela } \\
\text { podaho dela Luna } \\
\text { noua fa molts rahims } \\
\text { menuts e moltes } \\
\text { serments sotils }\end{array}$ & \\
\hline $\begin{array}{l}\text { [fol. 2I3v] Todo } \\
\text { majuelo de sarmjento } \\
\text { se deue tajar de luna } \\
\text { vieja. E puede se } \\
\text { plantar en luna nueua. }\end{array}$ & $\begin{array}{l}\text { [fol. 95v34] Tot mayol } \\
\text { de sarment se deu } \\
\text { tallar de lluna vella y } \\
\text { pot se plantar en lluna } \\
\text { noua }\end{array}$ & $\begin{array}{l}\text { [fol. } 3 \text { ov] De altra } \\
\text { manera de plantar } \\
\text { vinya. Tot home qui } \\
\text { vol plantar vinya deu } \\
\text { podar los sarments } \\
\text { que vol plantar } \\
\text { prenent los de vinya } \\
\text { vella. E quant seras en } \\
\text { la luna plena aquell } \\
\text { dia o pasats dos o tres } \\
\text { dies nomes en la vella } \\
\text { lauos planta la vinya. } \\
\text { [fol. } 3 \text { Ir] Empero si } \\
\text { fer se pot abans que } \\
\text { la plantes met les } \\
\text { sarments ha remullar } \\
\text { alguns dies e despuys } \\
\text { plantales e met hi } \\
\text { terra, ço és, de aquella } \\
\text { quj esta en la fas de la } \\
\text { terra una ma en gros } \\
\text { e puys la quey estava } \\
\text { primer e aços fa per } \\
\text { que per les sarments } \\
\text { meten les raels en la } \\
\text { terra moguda e puys } \\
\text { donalj aygua. E com } \\
\text { te dit damunt com } \\
\text { pendras les sarments } \\
\text { prenles de vinya } \\
\text { vella e guarda com } \\
\text { plantaras les sarments } \\
\text { fes per guisa que aja } \\
\text { de sep a sep ho dotze } \\
\text { pams ha tots quayres e } \\
\text { apres a cap de .xv. dies } \\
\text { ho tres semanas regala } \\
\text { e caua la fonda fins al } \\
\text { maig. }\end{array}$ & $\begin{array}{l}\text { [fol. IIor] [I.2] De } \\
\text { plantar vinya. Tot } \\
\text { hom qui vol plantar } \\
\text { vinya deu podar } \\
\text { los mayols que deu } \\
\text { metra en luna vella } \\
\text { ço es passada la plena } \\
\text { hun dja o dos com } \\
\text { pus prop mes ne val } \\
\text { e stoig los mallols } \\
\text { tro ala Luna noua e } \\
\text { crexent que haia deu } \\
\text { dies tro en quatorza e } \\
\text { lauors plant E si per } \\
\text { ventura lo mallol era } \\
\text { mustiu meta lo cap del } \\
\text { mallol vna njt en aygua } \\
\text { e lo dia seguent plant } \\
\text { e no fallira Es ver } \\
\text { quel mallol dela vinya } \\
\text { vella que hage de xij. } \\
\text { anys en sus pren mjls } \\
\text { quel dela vinya noua } \\
\text { Empero lo clot que } \\
\text { faras per al mallol la } \\
\text { terra quen trauras } \\
\text { no le y tornes mas } \\
\text { rebbleix lo daltre terra } \\
\text { e hage de cep a cep } \\
\text { vij. palms de alna de } \\
\text { valencia a tots cayres } \\
\text { amanera de taulell de } \\
\text { stachs } \\
\\
\end{array}$ & \\
\hline
\end{tabular}




\begin{tabular}{|c|c|c|c|c|}
\hline $\begin{array}{l}M \text { (Madrid) } \\
\text { BNE IO2II }\end{array}$ & $\begin{array}{l}V \text { (Valencia) } \\
\text { BMSM 6437 }\end{array}$ & $\begin{array}{l}\text { P(Paris) } \\
\text { BnF esp. 29I }\end{array}$ & $\begin{array}{l}B \text { (Barcelona) } \\
\text { BCB } 754\end{array}$ & $\begin{array}{l}N \text { (Naples) } \\
\text { Branc III AII }\end{array}$ \\
\hline $\begin{array}{l}\text { [fol. 2I3v] Todo } \\
\text { arbol que tenga foja } \\
\text { continuadamente se } \\
\text { deue trasplantar en } \\
\text { luna nueua. Todo } \\
\text { arbol que no tenga } \\
\text { la foja se puede } \\
\text { trasplantar en luna } \\
\text { vieja. }{ }^{\text {II }} \\
\text { I3I }\end{array}$ & $\begin{array}{l}\text { [fol. 95v35] Tot arbre } \\
\text { que tinga la fulla } \\
\text { continuament se deu } \\
\text { tresplantar en lluna } \\
\text { noua. }\end{array}$ & & & $\begin{array}{l}\text { [fol. } 54 \mathrm{v}] \text { Tot arbre } \\
\text { que vulles empeltar } \\
\text { o plantar fe ho en la } \\
\text { luna crexent }{ }^{182}\end{array}$ \\
\hline $\begin{array}{l}\text { [fol. 2I4r] Antes } \\
\text { quelos arboles se } \\
\text { arranquen se deuen } \\
\text { aseñyalar en manera } \\
\text { que al trasplantar } \\
\text { esten por aquellas } \\
\text { señyales mesmas que } \\
\text { estauan } \\
\text { I32 }\end{array}$ & $\begin{array}{l}\text { [fol. } 96 \mathrm{rr} \text { ] Ans quels } \\
\text { arbres se arranquen } \\
\text { se deuen senyalar } \\
\text { enmanera que al } \\
\text { tresplantar stiguen } \\
\text { per aquelles senyes } \\
\text { mateixes ques stauen }\end{array}$ & $\begin{array}{l}\text { [fol. } 34 \mathrm{v} \text { ] E nota tu } \\
\text { coltivador de la terra }{ }^{183} \\
\text { que quant volras } \\
\text { plantar hun arbre de } \\
\text { hun loch en altre que } \\
\text { tingas esment la part } \\
\text { deues leuant que com } \\
\text { lo plantaras lo tornes } \\
\text { en aquella matexa } \\
\text { manera. }\end{array}$ & & $\begin{array}{l}\text { [fol. } 54 \mathrm{v} \text { ] e guarda } \\
\text { quela part que tenja } \\
\text { vers lo sol ixent tenga } \\
\text { aximateix quant lauras } \\
\text { transplantat en lo loch } \\
\text { hon lo transplantaras }\end{array}$ \\
\hline I33 & & & & $\begin{array}{l}\text { [fol. } 54 \mathrm{v} \text { ] e dela deena } \\
\text { fins ala xv luna es } \\
\text { millor e fa mes fruyt. }\end{array}$ \\
\hline $\begin{array}{l}\text { [fol. 2I4r] E queles } \\
\text { sean fechas grandes } \\
\text { cauas \& fondas con } \\
\text { mucho estiercol. E } \\
\text { que sean rregados } \\
\text { muchas vezes. } \\
\text { I34 }\end{array}$ & $\begin{array}{l}\text { [fol. } 96 \mathrm{r} \text { ] y quels sien } \\
\text { fetes grans claueres y } \\
\text { fondes ab molts fems y } \\
\text { que sien tenguts molt } \\
\text { aprop de regar }\end{array}$ & & & \\
\hline $\begin{array}{l}\text { [fol. 2I } 4 \mathrm{r} \text {, in the } \\
\text { margin, by a second } \\
\text { hand, the note } \\
\text { "enxerjr"] } \\
\text { I35 }\end{array}$ & & $\begin{array}{l}\text { [fol. 42v] Terç. Del } \\
\text { libre terç Paladi. } \\
\text { Lo qual trachta de } \\
\text { empeltar arbres, } \\
\text { vinyes, pares, } \\
\text { hortalices. } \\
\end{array}$ & & $\begin{array}{l}{[54 \mathrm{v}] \text { De empaltar }} \\
\text { tot arbre quj leua } \\
\text { fruyt }\end{array}$ \\
\hline $\begin{array}{l}{[\text { fol. 2I4r }] \text { Enel }} \\
\text { enxerir deue hombre } \\
\text { guardar dos cosas } \\
\text { I36 }\end{array}$ & $\begin{array}{l}\text { [fol. g6r] En lo } \\
\text { empeltar deu hom } \\
\text { guardar dues coses }\end{array}$ & $\begin{array}{l}\text { [fol. 42v] Quant hom } \\
\text { vol empeltar dos coses } \\
\text { se deu guardar: }\end{array}$ & $\begin{array}{l}\text { [fol. II4v] [3.I.I] } \\
\text { Com vol empaltar } \\
\text { dues coses deu hom } \\
\text { guordar }\end{array}$ & $\begin{array}{l}{[54 \mathrm{v}] \text { Al empeltar deu }} \\
\text { hom guardar dues } \\
\text { coses }\end{array}$ \\
\hline
\end{tabular}

I8I. The agricultural miscellany of BNMio2II (beginning at fol. 2IIr) and BMSM 6437 (beginning at 94V) has two chapters giving an expanded version of these two sentences; see Capuano 2009.

I82. This section precedes the paragraph that begins "Al empeltar deu hom guardar dues coses..." on the same folio, $54 \mathrm{v}$.

I83. This section appears in a chapter dealing with the propagation of fig trees, and comes under the heading "Del libre segon paladj” beginning on the previous folio side $(34 \mathrm{r})$. 


\begin{tabular}{|c|c|c|c|c|}
\hline $\begin{array}{l}M \text { (Madrid) } \\
\text { BNE IO2II } \\
\end{array}$ & $\begin{array}{l}\text { V(Valencia) } \\
\text { BMSM 6437 } \\
\end{array}$ & $\begin{array}{l}P \text { (Paris) } \\
\text { BnF esp. 29I }\end{array}$ & $\begin{array}{l}\text { B (Barcelona) } \\
\text { BCB 754 }\end{array}$ & $\begin{array}{l}N \text { (Naples) } \\
\text { Branc III AII } \\
\end{array}$ \\
\hline $\begin{array}{l}\text { [fol. 2I/rr] La vna que } \\
\text { el Arbol que deue } \\
\text { ser enxerido sea en } \\
\text { sabea. E la otra quelos } \\
\text { enxiertos non sean } \\
\text { brotados njn ayan } \\
\text { algunt borro abierto } \\
\text { sy non que sean } \\
\text { aparejados de brotar } \\
\text { con que non ayan los } \\
\text { cabos gruessos } \\
\text { I37 }\end{array}$ & $\begin{array}{l}\text { [fol. 96r] la huna quel } \\
\text { arbre que deu esser } \\
\text { empeltat sia en sabea } \\
\text { laltra quels exercos no } \\
\text { sien brotats ne hagen } \\
\text { algun borro cubert } \\
\text { mas que sia aparellat } \\
\text { de brotar ab que no } \\
\text { haia los caps grossos }\end{array}$ & \begin{tabular}{|l|} 
[fol. 42v] que larbre \\
qui vol empeltar \\
estiga de saho; la \\
segona quel exerç \\
no aja brotat nj aja \\
huberts los borrons \\
mas que sen aparell \\
que mes val [fol. 43r] \\
que no aja lo cap gros \\
ne inflat.
\end{tabular} & $\begin{array}{l}\text { [fol. II yv] la primera } \\
\text { quel arbre que hom } \\
\text { vol empaltar que sia } \\
\text { en saba la segona } \\
\text { quel exerç que hom } \\
\text { vol metre que no sia } \\
\text { bro(c)[t]at nj hage } \\
\text { vbert lo borro mas } \\
\text { ques apparell de } \\
\text { brotar que mes val que } \\
\text { no hage lo cap gros ne } \\
\text { jnflat } \\
\end{array}$ & $\begin{array}{l}\text { [fol. 54v] la prima } \\
\text { quel arbre sia en saba. } \\
\text { Segona quel exerç } \\
\text { que hom vol metre } \\
\text { no sia brotat ne hage } \\
\text { lo borro ma com } \\
\text { saparella de brotar ab } \\
\text { que empero no haia lo } \\
\text { cap gros ne jnflat }\end{array}$ \\
\hline $\begin{array}{l}\text { [fol. 2I/4r] Eaquesto } \\
\text { se faze comun mente } \\
\text { en febrero. }\end{array}$ & $\begin{array}{l}\text { [fol. } 96 \mathrm{r} \text { ] y aço se } \\
\text { fa comunament en } \\
\text { febrer. }\end{array}$ & $\begin{array}{l}\text { [fol. } 43 \text { r] E aço se deu } \\
\text { fer magorment en } \\
\text { febrer fins a la festa de } \\
\text { Sent Maçia la qual es } \\
\text {.v. dies a la desexida }{ }^{184} \\
\text { de febrer. }\end{array}$ & $\begin{array}{l}\text { [fol. II } 4 \text { V] e aço deuets } \\
\text { fer maiorment en } \\
\text { lo mes de febrer tro } \\
\text { ala ffesta de sanct } \\
\text { Macia la qual es a .v. } \\
\text { djes dela desaxida de } \\
\text { febrer }\end{array}$ & $\begin{array}{l}\text { [fol. } 54 \mathrm{v}] \text { e aço deu fer } \\
\text { en lo mes de ffebrer } \\
\text { en torn la festa de sant } \\
\text { Matia que es a .xxiiii. } \\
\text { de ffebrer. }\end{array}$ \\
\hline 139 & & $\begin{array}{l}\text { [fol. } 43 \text { r] E haquesta } \\
\text { fa algunes vegades } \\
\text { cuytar o tardar segons } \\
\text { que cuyten es tarden } \\
\text { deborar los arbres e } \\
\text { segons los linatges } \\
\text { axi com son ametles } \\
\text { e çirers de tals nia e } \\
\text { enla entrada de febrer } \\
\text { e aso segons se cuyten } \\
\text { es tarden. }\end{array}$ & \begin{tabular}{|l|} 
[fol. IIfv] e aço fa \\
avagades acuytar e \\
auagades atardar \\
segons los arbres \\
que cuyten a brotar \\
os tarden e segons lo \\
linatge del arbre axi \\
com amellers que fan \\
empaltar en Giner \\
e cire[r]s que fan \\
empaltar en la entrada \\
de febrer de tals nj ha \\
E aço es segons ques \\
cuyten os tardan \\
\end{tabular} & $\begin{array}{l}{[\text { fol. 54v] E aço fa }} \\
\text { auegades a cuytar o } \\
\text { atardar segons quels } \\
\text { arbres se cuyten a } \\
\text { brotar o tarden }\end{array}$ \\
\hline 140 & & \begin{tabular}{|l|} 
[fol. 43r, continued] \\
Mas veritat es que la \\
major part dels arbres \\
qui no tenen fulla \\
axj com son peres e \\
prunes e magranes \\
fan ampeltar en torn la \\
festa de Sant Maçja.
\end{tabular} & $\begin{array}{l}\text { [fol. IIfv, continued] } \\
\text { Mas ver es que la } \\
\text { maior força dels } \\
\text { arbres que no tenen } \\
\text { fulla axi com pereres } \\
\text { sarmenyeres e daltres } \\
\text { arbres magraners fan } \\
\text { empaltar entorn la } \\
\text { festa de sanct macia } \\
\end{array}$ & $\begin{array}{l}\text { [fol. } 54 \mathrm{v}] \text { E es veritat } \\
\text { quela maior partida } \\
\text { dels arbres que no } \\
\text { tenen fulla, axicom } \\
\text { [fol. } 55 \text { r] peres, } \\
\text { sermenyes, pruners } \\
\text { e altres semblants fan } \\
\text { a empeltar entorn la } \\
\text { festa de sant Marcia. }\end{array}$ \\
\hline I4I & & & & \begin{tabular}{|l|} 
[fol. 55 r] En cirer \\
pots empeltar \\
preseguer alberger \\
poma pressech e \\
pruner e nepler e \\
altre cirer. Serments \\
fan empeltar dela dita \\
festa de sant Marcia \\
\end{tabular} \\
\hline
\end{tabular}

I84. I.e., five days before the end of February. 


\begin{tabular}{|c|c|c|c|c|}
\hline $\begin{array}{l}M \text { (Madrid) } \\
\text { BNE IO2II } \\
\end{array}$ & $\begin{array}{l}V \text { (Valencia) } \\
\text { BMSM 6437 }\end{array}$ & $\begin{array}{l}\text { P(Paris) } \\
\text { BnF esp. 29I }\end{array}$ & $\begin{array}{l}B \text { (Barcelona) } \\
\text { BCB } 754 \\
\end{array}$ & $\begin{array}{l}N \text { (Naples) } \\
\text { Branc III AII }\end{array}$ \\
\hline I 42 & & & & $\begin{array}{l}\text { [fol. } 55 \text { r, continued] } \\
\text { tro a mijant Mars en la } \\
\text { luna crexent tota via. }\end{array}$ \\
\hline $\begin{array}{l}\text { [fol. 2I/4r] Las çepas } \\
\text { se deuen enxerir } \\
\text { mediado mayio. } \\
\text { I } 43\end{array}$ & $\begin{array}{l}\text { [fol. } 96 \mathrm{r}] \text { Los çeps } \\
\text { deuen empeltar a } \\
\text { mijant maig. }\end{array}$ & & & \\
\hline $\begin{array}{l}\text { [fol. 2I4r, continued] } \\
\text { Oliueras se enxieren } \\
\text { en abril. }\end{array}$ & $\begin{array}{l}\text { [fol. } 96 \mathrm{r} \text {, continued] } \\
\text { Oliueres se empelten } \\
\text { en abril. }\end{array}$ & $\begin{array}{l}\text { [fol. 47v] De } \\
\text { empeltar oliuera. } \\
\text { Oliuera se deu } \\
\text { empeltar axj com la } \\
\text { figuera en lo mes de } \\
\text { abril. Axj matex se } \\
\text { pot empeltar en lo } \\
\text { mes de maig abans } \\
\text { que comens a florir } \\
\text { descudet, e si es } \\
\text { empeltada ascudet } \\
\text { liga molt be lescudet } \\
\text { ab escorça de figuera } \\
\text { per que es letossa } \\
\text { e calda de natura } \\
\text { e ajuda lj molt. E } \\
\text { encara afluya quant } \\
\text { es sequa e tanbe } \\
\text { se pot empeltar de } \\
\text { broqua entre lo fust } \\
\text { e la escorça en luna } \\
\text { crexent e fes sia ben } \\
\text { ligada o ligat lempelt } \\
\text { ab corda despart. }\end{array}$ & & \\
\hline
\end{tabular}




\begin{tabular}{|c|c|c|c|c|}
\hline $\begin{array}{l}M \text { (Madrid) } \\
\text { BNE IO2II } \\
\end{array}$ & $\begin{array}{l}V \text { (Valencia) } \\
\text { BMSM 6437 }\end{array}$ & $\begin{array}{l}\text { P(Paris) } \\
\text { BnF esp. 29I }\end{array}$ & $\begin{array}{l}B \text { (Barcelona) } \\
\text { BCB } 754 \\
\end{array}$ & $\begin{array}{l}N \text { (Naples) } \\
\text { Branc III AII } \\
\end{array}$ \\
\hline $\begin{array}{l}\text { FFigueras a sant } \\
\text { iohan de Junjo }\end{array}$ & $\begin{array}{l}\text { Figueres a sent Johan } \\
\text { de Juny. }\end{array}$ & $\begin{array}{l}\text { [fol. 43v] De } \\
\text { empeltar figueres. } \\
\text { Figueres fan ha } \\
\text { empeltar en torn la } \\
\text { festa de sant Johan } \\
\text { de Juny. E son .iij. } \\
\text { maneres de empeltar. } \\
\text { La primera es entre } \\
\text { la scorça e lo fust e la } \\
\text { segona es enlo tronch } \\
\text { fes [sic] mas sia lexat } \\
\text { lo cor a vna banda he } \\
\text { lo exerç o la gulla sia } \\
\text { longa. La terçera es } \\
\text { escudet, com lescut } \\
\text { o la gulla sia lonch } \\
\text { e gran pero dejus la } \\
\text { escorça dela figuera. } \\
\text { E enpeltar figueres } \\
\text { e holiueres sempre } \\
\text { se deu fer en jener } \\
\text { empero los empelts } \\
\text { o exerç que hom } \\
\text { vol empeltar deuen } \\
\text { eser de hun any so } \\
\text { es a saber que sien } \\
\text { nats en lany pasat e } \\
\text { sien ben speços de } \\
\text { borrons e que hom } \\
\text { los prenga de sol } \\
\text { ixent he en aquella } \\
\text { matexa ensenya lo } \\
\text { torna. Axj matex sen } \\
\text { pot empeltar en la } \\
\text { entrada de març fins } \\
\text { al dia de sant berbeurs5 } \\
\text { o sant bernabeu. E si } \\
\text { mets empelt de fruyt } \\
\text { vell met lo en fruyt } \\
\text { vell e lo nou en nou } \\
\text { e tota hora en lluna } \\
\text { vella. Axj matex les } \\
\text { pots empeltar de sant } \\
\text { barnabeu entro a } \\
\text {.viiijo. dies passat sent } \\
\text { johan e guarda quel } \\
\text { scudet no sia foradat }\end{array}$ & & $\begin{array}{l}\text { [fol. } 55 \text { r, continued] } \\
\text { De empeltar } \\
\text { figueres. Ffigueres } \\
\text { fan empeltar entorn } \\
\text { dela festa de sant } \\
\text { Johan de juny .viij. o } \\
\text {.xv. dies. E son tres } \\
\text { maneres dempeltar } \\
\text { la vna manera es en } \\
\text { tronch entre lo fust e } \\
\text { la escorsa. E laltre en } \\
\text { tronch fes per lo mig. } \\
\text { Mas deu hom lexar } \\
\text { tot lo cor dela vna } \\
\text { part. E aquestes dues } \\
\text { maneres se empelten } \\
\text { ab exerchs lonchs. } \\
\text { La terça manera de } \\
\text { escorça ab vll e ab } \\
\text { borro que hom met } \\
\text { dins la scorxa del } \\
\text { arbre per manera } \\
\text { quel vll e lo borro que } \\
\text { hom met no estiguen } \\
\text { cuberts dela escorxa } \\
\text { mas com es ben ligat } \\
\text { cobre hom lull o borro } \\
\text { ab un parell de fulles } \\
\text { de figuera e apres } \\
\text {.viij. dies leuales ne } \\
\text { hom e lo borro met } \\
\text { son cap e son vll. }\end{array}$ \\
\hline
\end{tabular}

I85. What appears to be the same scribal hand has inserted -na-above this name, thus correcting it to "bernabeu", as written immediately thereafter. The feast of St. Barnabas is June II. 


\begin{tabular}{|c|c|c|c|c|}
\hline I 45 & & $\begin{array}{l}\text { (cont.) } \\
\text { nj toquat de pedra e } \\
\text { viura. Encara se pot } \\
\text { empeltar figuera en la } \\
\text { entrada de abril pero } \\
\text { de agulla [fol. 44r] } \\
\text { entre lo tronch e la } \\
\text { escorça a vn palm e } \\
\text { mig de terra pero que } \\
\text { tem molt lo vent. }\end{array}$ & & \\
\hline $\begin{array}{l}\text { [fol. 2I4r, continued] } \\
\text { Los enxiertos deuen } \\
\text { ser bien espesos de } \\
\text { borrons. E que sean } \\
\text { del Añyo pasado } \\
\text { I46 }\end{array}$ & $\begin{array}{l}\text { [fol. } 96 \mathrm{r} \text {, continued] } \\
\text { Los exercos deuen } \\
\text { ser ben espessos de } \\
\text { borrons y que sien del } \\
\text { any passat }\end{array}$ & $\begin{array}{l}\text { [fol. } 43 \text { r] Los exerç } \\
\text { que hom vol empeltar } \\
\text { deuen esser de hun } \\
\text { any pasat, e que sien } \\
\text { ben spesos de borons, }\end{array}$ & $\begin{array}{l}\text { [fol. II4V] [3.I.2] Los } \\
\text { exerços que deu hom } \\
\text { empaltar deuen esser } \\
\text { de hun any pessat e } \\
\text { que sien be spessos ab } \\
\text { borrons }\end{array}$ & $\begin{array}{l}\text { [fol. } 55^{\mathrm{r}} \text {, continued] } \\
\text { Empero lo [sic] exerts } \\
\text { que hom deu metre } \\
\text { deuen esser de vn any, } \\
\text { ço es que deuen esser } \\
\text { nats en lany passat e } \\
\text { sien be espessos de } \\
\text { borrons }\end{array}$ \\
\hline 147 & & $\begin{array}{l}\text { [fol. } 43 \text { r, continued] e } \\
\text { que sien sforcats, }\end{array}$ & $\begin{array}{l}\text { [fol. II } 4 \mathrm{~V}, \text { continued] } \\
\text { e que sien sforçats }\end{array}$ & $\begin{array}{l}\left.\text { [fol. } 55^{\mathrm{r}} \text {, continued }\right] \mathrm{e} \\
\text { sien forrats }[\mathrm{sic}]\end{array}$ \\
\hline $\begin{array}{l}\text { [fol. 2I4r, continued] } \\
\text { E que guarden enta } \\
\text { sol ixiente E al enxerir } \\
\text { deuen estar por } \\
\text { semblante forma. }\end{array}$ & $\begin{array}{l}\text { [fol. } 96 \text { r, continued] } \\
\text { y que stiguen vers lo } \\
\text { sol ixent y al empeltar } \\
\text { deuen star per } \\
\text { semblant forma }\end{array}$ & $\begin{array}{l}\text { [fol. 43r, continued] } \\
\text { e que hom los prenga } \\
\text { de part del sol ixent } \\
\text { en lo mes de febrer. } \\
\text { Deu hom empeltar } \\
\text { en lo tronch o en } \\
\text { la scorça. Mas per } \\
\text { que en lo principi } \\
\text { daquest libre e parlat } \\
\text { tant d'enpeltar remet } \\
\text { alla. }{ }^{186} \\
\end{array}$ & $\begin{array}{l}\text { [fol. II4v, continued] } \\
\text { e que hom los prenga } \\
\text { deues lo sol ixent en } \\
\text { lo mes de febrer deu } \\
\text { hom empaltar en lo } \\
\text { tronch o en la scorsa }\end{array}$ & $\begin{array}{l}\text { [fol. } 55^{\mathrm{r}} \text {, continued] e } \\
\text { quels prenga hom vers } \\
\text { sol ixent. }\end{array}$ \\
\hline $\begin{array}{l}\text { [fol. 2I/4r, continued] } \\
\text { E la fendedura que } \\
\text { hombre faze enel } \\
\text { arbol que enxiere } \\
\text { deue guardar al } \\
\text { sol ixiente \& al sol } \\
\text { ponjente. } \\
\text { I49 }\end{array}$ & $\begin{array}{l}\text { [fol. } 96 \mathrm{r} \text {, continued] } \\
\text { y la fenedura que fa } \\
\text { hom en larbre que } \\
\text { empelta deu guardar } \\
\text { a sol ixent y a sol } \\
\text { ponent }\end{array}$ & & & \\
\hline 150 & & $\begin{array}{l}\text { [fol. } 5 \text { or] De collir } \\
\text { fruyta per saluar. La } \\
\text { fruyta que hom vol } \\
\text { per saluar axj com } \\
\text { magranes, pomes, } \\
\text { peres, etcetera, deuen } \\
\text { esser colides en luna } \\
\text { vella per que sens } \\
\text { dupte nengu sen } \\
\text { saluen mjllor. } \\
\end{array}$ & $\begin{array}{l}{[\text { fol. II v }] \text { 3·37 De }} \\
\text { cullir fruyta per } \\
\text { saluar. Tota fruyta } \\
\text { que hom vulla per } \\
\text { saluar axi com } \\
\text { magranes pomes } \\
\text { peres e altres fruytes } \\
\text { semblants deuen esser } \\
\text { cullides en la luna } \\
\text { vella }\end{array}$ & $\begin{array}{l}\text { [fol. } 55 \text { r] De tota } \\
\text { fruyta per a saluar. } \\
\text { Tota fruyta per saluar } \\
\text { axicom son rayms, } \\
\text { magranes, pomes, } \\
\text { peres, e altres fruytes } \\
\text { per conseruar en casa } \\
\text { deuen esser cullides } \\
\text { en luna vella }\end{array}$ \\
\hline
\end{tabular}

I86. See Martí Escayol 20I2: Io8, footnote 77. 


\begin{tabular}{|c|c|c|c|c|}
\hline $\begin{array}{l}M \text { (Madrid) } \\
\text { BNE IO2II }\end{array}$ & $\begin{array}{l}V \text { (Valencia) } \\
\text { BMSM 6437 }\end{array}$ & $\begin{array}{l}\text { P(Paris) } \\
\text { BnF esp. 29I }\end{array}$ & $\begin{array}{l}\text { B (Barcelona) } \\
\text { BCB } 754 \\
\end{array}$ & $\begin{array}{l}N \text { (Naples) } \\
\text { Branc III AII }\end{array}$ \\
\hline I5 I & & $\begin{array}{l}\text { [fol. 5or, continued] E } \\
\text { deu les hom colir que } \\
\text { no sien mullades ne } \\
\text { façes que sien m[a]- } \\
\text { ça madures que elles } \\
\text { se’n adoben molt be, } \\
\text { maxime com estan } \\
\text { entre palla hun temps } \\
\text { e puys sien penjades } \\
\text { de dues en dues en } \\
\text { loch hon toque e pase } \\
\text { ayre. } \\
\end{array}$ & $\begin{array}{l}\text { [fol. IIzv, continued] } \\
\text { e deu les hom cullir } \\
\text { que no sien massa } \\
\text { madures. }\end{array}$ & $\begin{array}{l}\text { [fol. } 55^{\text {r, continued] }} \\
\text { e que sens colpeiar } \\
\text { sien conseruades en } \\
\text { un porxo vbert ala } \\
\text { tramuntana. }{ }^{187}\end{array}$ \\
\hline $\begin{array}{l}\text { [fol. 2I3v8] Qui quiere } \\
\text { plantar vna mujada de } \\
\text { tierra de vjñya espessa } \\
\text { ha menester .v. mil } \\
. \text { dcxxv. majuelos }{ }^{88} \\
\text { I52 }\end{array}$ & $\begin{array}{l}\text { [fol. 95v] Qui vol } \\
\text { plantar huna mujada } \\
\text { de vinya espessa ha } \\
\text { mester mayols .v. mil } \\
\text {.dc. .xxv. }\end{array}$ & & & \\
\hline
\end{tabular}

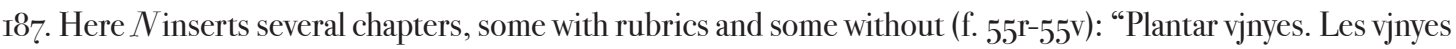
sien plantades en los lochs frets deuers mig Jorn. e en lo [sic] lochs calents vers tremuntana. Plantes de sarments. A plantar sarments valen mes e duren mes e leuen molt lo oduals, guarros, greo. atzenjms [unclear reading], monestrell, mas aquest no dura tant. Monestrell val mes que tots e leua be. rosega es bo. Les veçes engrexen la terra e maten les males herbes. les faues engrexen la terra mas no maten les males herbes. aximateix los lobins. Los pinyols de pressech se deuen plantar de ffebrer.Si vols saluar rayms cull los en luna vella e penials en la despensa o en la casa hon pascen e saluarsan. [fol. 55v] Contra arnes sin ha en cofrens haies flor de romanj e metets lo en la caxa e nonj entraran ans hi morran sin hi ha. Aquesta es la bona manera e vertadera de empeltar arbres e ceps. Si vols empeltar oljuera en garrofer podets ho fer en lo mes de abril o en Maig en luna noua que sia passada quinta e sia empeltat a palutxo o cadireta $o$ escudet e tota vegada per lescorxa. Figuera pots empeltar de Maig entre dues terres en luna vella o passat lo .viij.e e deu se fendre per lo mig del fust a palutxo e despuys sia cuberta de terra tro al cap del palutxo. Mas mes val empeltar la figuera sisfa mijant Maig fins a sant Johan de Juny en luna vella o noua passat lo .viij.e e que faça a palutxo o a cadireta 0 scudet tota vegada per lescorxa. Albrequoquer o ameller o cirer se volen empeltar de Janer en luna vella o noua passat lo .viij.e e deu se fendre lo fust per lo mig. e podets empeltar en prunera albrecoquer alberger e presseguer. Perera sermenyera perseguer alberger pomapressech. codonyer nespler e semblants arbrers se deuen empeltar a sant Macia en luna vella o noua passat lo .viij.e e sia fes larbre per lo mig a paltuxo e tallar laxerçs egual que noy haia fills e que vinga just vna escorça ab laltra. E si lo temps se cuytaue de brotar feu ho pus prest de sant Macia .viiij. o deu dies que es a .xxiiij. de ffebrer.En auellaner podets empeltar a sant Macia perseguer e alberger o pomapressech o dell mateix en luna dessus dita e sia empeltat per lescorça a palutxo e sia laxerç en saba e sino es en saba fenets lo e de Janer hi podets empeltar albrecoquer. Magraner se deu empeltar en lo mes de Juny com sera en flor hoy haia magranes que sien exides de flor a palutxo o cadireta per la scorça en luna vella o noua passat lo .viij.e Cep de tria o de vjnya pots empeltar en lo mes de Mars en luna vella de .x. en .xij. o en luna noua e sia fes per lo mig E silo cep ploraue feu lj vn tayll pus baix quel excerç e no sen peccara nengu. En lo mes de ffebrer pots empeltar noguer en arbosser e en pruner o de sa natura matexa de noguer".

I88. Ferrer Saiol inserts a comment to the same effect in his translation of the Opus agriculturae of Palladius $\$ 3.9 .9$, found in BMSM 6437 fols. 33 v-34r: "en huna mujada de terra de barçelona entren cinch milia sisçentes y xxv sarments. En huna mugada de terra ha sisçents y xxv. destrers ço es .XXv. destrers per cascun cayre”. In BNE IO2II the corresponding passage is on fols. 64v-65r: "En vna mujada de Barçelona de tierra entran Vo mjll \& DCXXV sarmjentos. En vna mujada de tierra ay DCXXV destrers, es a saber XXVo destrers por cada cayre" (Capuano I990: 70). The same passage is repeated later in the same two codices, as cited here. 


\begin{tabular}{|c|c|c|c|c|}
\hline $\begin{array}{l}M \text { (Madrid) } \\
\text { BNE IO2II } \\
\end{array}$ & $\begin{array}{l}V \text { (Valencia) } \\
\text { BMSM 6437 }\end{array}$ & $\begin{array}{l}\text { P(Paris) } \\
\text { BnF esp. 29I }\end{array}$ & $\begin{array}{l}\text { B (Barcelona) } \\
\text { BCB } 754\end{array}$ & $\begin{array}{l}N \text { (Naples) } \\
\text { Branc III AII }\end{array}$ \\
\hline I53 & $\begin{array}{l}\text { [fol. 95 }{ }^{\mathrm{v} 26} \text { ] Pinyons } \\
\text { Castanyes garrofes } \\
\text { Datils Amenles se } \\
\text { deuen sembrar en } \\
\text { giner en lluna noua } \\
\text { que haia viij o x dies y } \\
\text { nos deuen molt cobrir } \\
\text { de terra mas que sia } \\
\text { ben guaretada y fondo } \\
\text { cauada. }\end{array}$ & $\begin{array}{l}\text { [fol 38r] De sembrar } \\
\text { pins. Guardar deu } \\
\text { hom quelos pins no } \\
\text { sien tresplantats per } \\
\text { que no viurien, mas } \\
\text { sien presos pinyons } \\
\text { trets dela pinya sense } \\
\text { metre al foch sino } \\
\text { trets en manera que } \\
\text { sien sançes. Empero } \\
\text { alguns sembren los } \\
\text { pinyons de setembre } \\
\text { quant hom sembra lo } \\
\text { forment. E axi matex } \\
\text { se sembren, o dich } \\
\text { planten casta[n]yers } \\
\text { per que sien del any, } \\
\text { segons pus larch ne } \\
\text { parlat enlo capitol } \\
\text {.xx. e per ço sabreuga } \\
\text { açj. }{ }^{\text {189 }}\end{array}$ & $\begin{array}{l}\text { [fol. II3v] [2.I4] De } \\
\text { sembrar arbres. Quj } \\
\text { vol hauer pins e datil e } \\
\text { castanya e amellers e } \\
\text { noguers e guarroffes e } \\
\text { carrasques e oliueres } \\
\text { e lorers sembra } \\
\text { qualque fruyt que } \\
\text { vulles dels demunt } \\
\text { dits en lo mes de Janer } \\
\text { o de ffebrer com La } \\
\text { Luna hage .x. djes } \\
\text { que sia girada tro en } \\
\text {.xv. e guardat com } \\
\text { las plantaras que no } \\
\text { les metes pus pregon } \\
\text { de dos djts en traues } \\
\text { e posa la hon seran } \\
\text { plantats vna verga } \\
\text { per senyal [2.I5] De } \\
\text { pins Guardar deu } \\
\text { hom que los pins no } \\
\text { sien tresplantats per } \\
\text { tal com no viuen. } \\
\text { Jten deu hom metre } \\
\text {.iiij. o.v. pinyols } \\
\text { com hom los planta } \\
\text { e no sien mesos los } \\
\text { pinyols al foch mas } \\
\text { sien trenchades en } \\
\text { altre manera empero } \\
\text { alguns sembren los } \\
\text { pins en lo mes de } \\
\text { setembre com hom } \\
\text { sembra lo forment } \\
\text { o lordj Jtem deles } \\
\text { castanyes sien ne } \\
\text { meses dues que sian } \\
\text { del any mateix com } \\
\text { pus fresques les } \\
\text { pusques hauer }\end{array}$ & \\
\hline
\end{tabular}

I89. "sabreuga açj” (s'abreuga açi) 'it is abbreviated here'. Reference is to the "Capitol de castanyes o de lur multiplicaçio" in another text of the same codex $(P)$, 9r-9v (Martí Escayol 20I2: 78). 


\begin{tabular}{|c|c|c|c|c|}
\hline $\begin{array}{l}M \text { (Madrid) } \\
\text { BNE IO2II }\end{array}$ & $\begin{array}{l}V \text { (Valencia) } \\
\text { BMSM } 6_{437}\end{array}$ & $\begin{array}{l}P \text { (Paris) } \\
\text { BnF esp. 29I }\end{array}$ & $\begin{array}{l}\text { B (Barcelona) } \\
\text { BCB } 754 \\
\end{array}$ & $\begin{array}{l}N \text { (Naples) } \\
\text { Branc III AII } \\
\end{array}$ \\
\hline I54 & & $\begin{array}{l}\text { [fol. 4Ir] De plantar } \\
\text { arbres. Totes plantes } \\
\text { de arbres o de vinyes } \\
\text { se deuen fer en la } \\
\text { luna crexent quant a } \\
\text {.x. dies que es girada } \\
\text { entro ala luna plena, } \\
\text { e aço de cada luna e } \\
\text { los arbres e las vinyas } \\
\text { viuran e caregaran } \\
\text { mjllor. Empero quj } \\
\text { planta arbres deu } \\
\text { fer que los arenque } \\
\text { de dauall terra e de } \\
\text { magra e dexuta e } \\
\text { que la meta en bona } \\
\text { terra e fan se mjllor } \\
\text { que altres. Empero } \\
\text { acceptat la figuera } \\
\text { que vol luna vella }\end{array}$ & $\begin{array}{l}\text { [fol. II } 4 \text { v] [2.24] De } \\
\text { plantar arbres. Totes } \\
\text { plantes de arbres se } \\
\text { façen en luna crexent } \\
\text { com ha .x. djes que es } \\
\text { girada entro en la luna } \\
\text { plena de cada luna } \\
\text { els arbres e les vinyes } \\
\text { viuran e carreguaran } \\
\text { Empero qui planta } \\
\text { arbres deu fer quels } \\
\text { meta en bona terra e } \\
\text { fer se han millors que } \\
\text { altres arbres. }\end{array}$ & 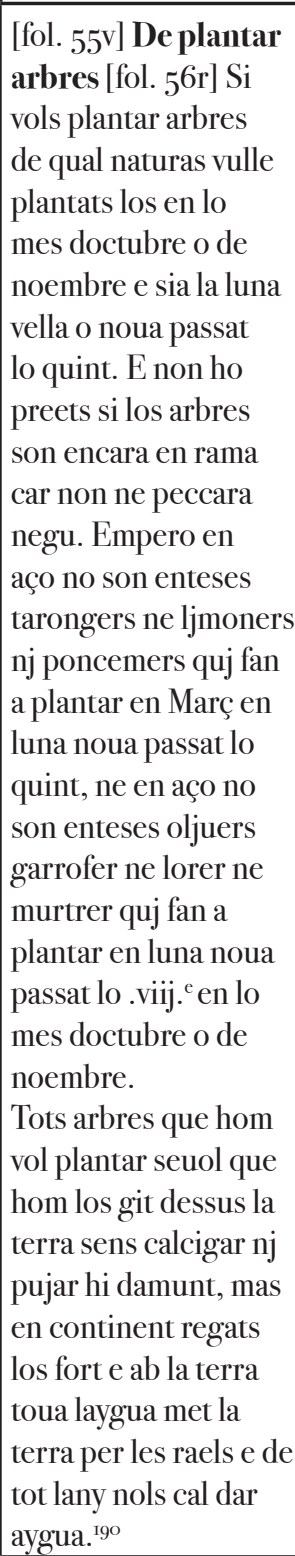 \\
\hline
\end{tabular}

I9o. Here $N$ continues (f. 56 r): "Si vols plantar branques de figuera fets ho en lo mes de Mars en luna vella o noua. e si fer se pot la brancha haia de lonch .v. o .vj. palms e sia plantada ab tots los branchons e cuberta de terra la maior brancha e pus longa que no hisque mes dun palm de sobre terra e leuara tantost fruyt com la figuera que sera plantada ab les raels pero sia regada tantost. Diu se que en prunera vjn empelt de perera e de pomer e de nespler". This passage is followed by the chapter on pruning cited above ("del podar delos sarments"; see rows I26-I28), and the folio side (56r) closes with the rubric "De empelta a escudet". Folio $56 \mathrm{v}$ contains this final chapter on shield grafting: "lempeltar de escudet se fa en aquesta manera. Si es de arbre que no perda fulla, axi com ljmoner, poncemer, naronger, e taronger es mester que lany passat que dels brots tendres hom haia trencades les spines, e al temps ques deu empeltar en laltre any ya es clos lo forat resta e pren hom lescudet, e abans que hom lo trague della hon es hom deu apparellar lo loch hon ha estar e apres traure lescudet e metrell dintre e ligar lo damunt e deuall ab vn espart e strenyer lo en manera que lo escudet no prenga mutacio per lestrenyer sino no vjura. Aximateix que com empeltareu lo sol nol toch, e que cuujdes [sic] laureu tret delaun loch ja sia en altre per ço no prengue del ayre, e apres ligar lj vna fulla damunt per raho daygua o aximateix de sol e aquests nos deuen empeltar fins quelos tarongers broten e han quatre dits de lonch e tots temps en luna crexent". 


\section{Appendix II: Comparison of a sample Memòria chapter with corresponding chapters in six representative medieval treatises on agriculture}

In an effort to demonstrate the notable independence of the Memòria from the diverse Latin and Arabic agronomic traditions that predominate in the medieval period, we have gathered into this appendix the chapters on lettuce cultivation presented in six of the major representative Classical and Arabic agricultural writings. A careful comparison of all these texts will show that the simple and unpretentious Memòria treatment of this crop, despite the concern it seems to share with Ibn al-Awwam for the correct timing of successive lettuce plantings, shows no convincing evidence of derivation from this or any of the other texts. Although space does not allow for an exhaustive comparison with the full gamut of medieval agricultural texts, it should be borne in mind that many of those not included here borrow heavily from these. For example, the chapter "De lactuce cultura" of the Speculum naturale of Vincent of Beauvais (Book XI, chapter 77) is indebted primarily to Pliny and Palladius, while the chapter "De la lechuga" in the translation by Vicente de Burgos (Book XVII, chapter 93) of the De proprietatibus rerum of Bartholomaeus Anglicus quotes St. Isidore and concerns itself primarily with the medicinal qualities of the plant (f. 229r). 


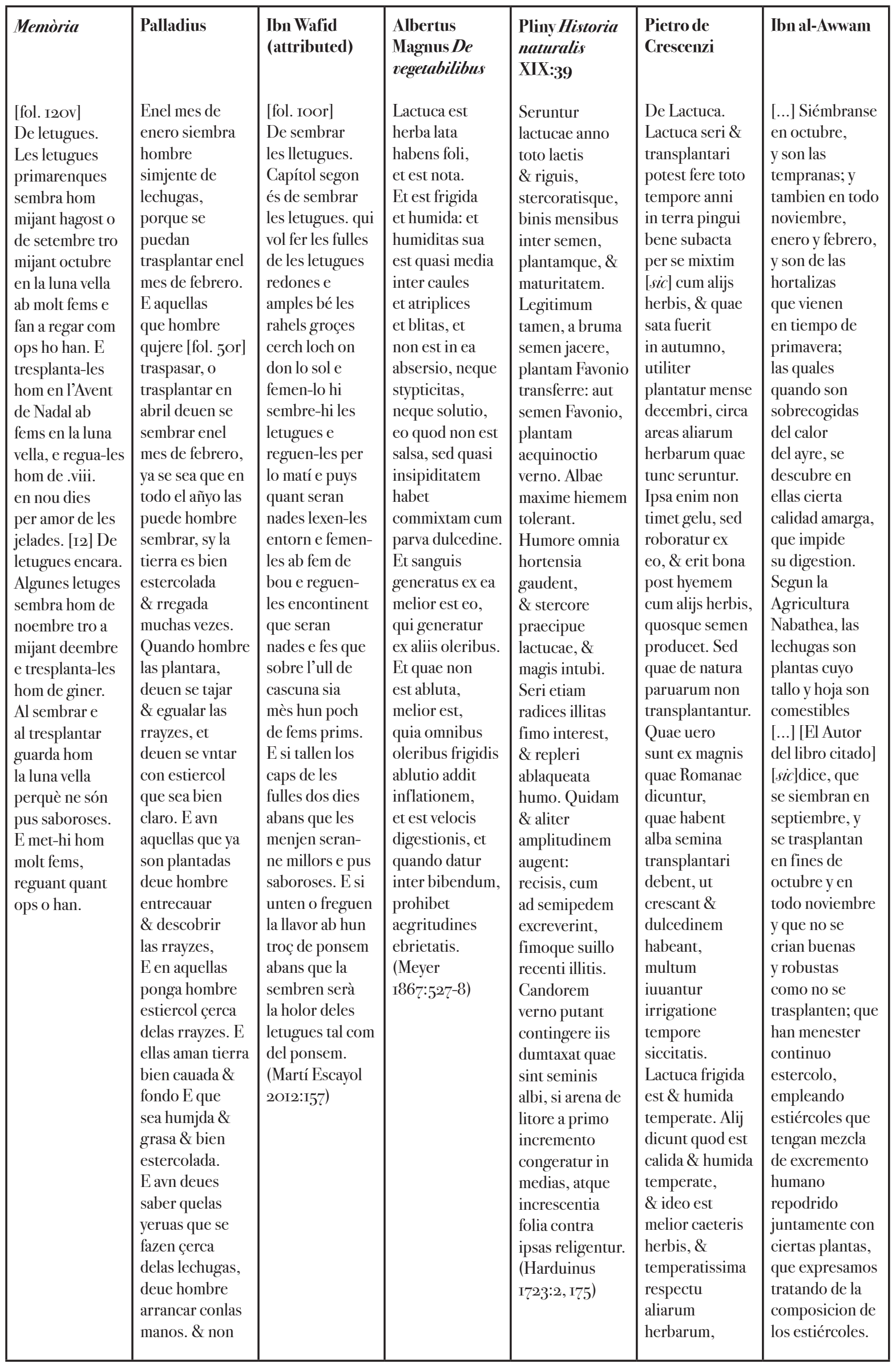




\begin{tabular}{|c|c|c|c|c|c|c|}
\hline Memòria & $\begin{array}{l}\text { Palladius } \\
\\
\text { deue hombre } \\
\text { arrancar conlas } \\
\text { manos. \& non } \\
\text { con açadon. } \\
\text { La lechuga se } \\
\text { faze mas ancha } \\
\text { sy hombre las } \\
\text { planta rralas. } \\
\text { E quando } \\
\text { començara } \\
\text { fazer espiga, } \\
\text { o meter ojo, la } \\
\text { vegada le deue } \\
\text { hombre cortar } \\
\text { el ojo \& meter } \\
\text { desuso algunt } \\
\text { terron, o algunt } \\
\text { tiesto. E faze } \\
\text { se mas ancha. } \\
\text { Las lechugas } \\
\text { se faran anchas } \\
\text { \& blancas sy } \\
\text { muchas vezes les } \\
\text { echa hombre de } \\
\text { suso en medio } \\
\text { del ojo arena } \\
\text { de rrio, o de } \\
\text { mar. E despues } \\
\text { que hombre ha } \\
\text { vistas las fojas } \\
\text { quelas fagas } \\
\text { estar ligadas } \\
\text { todas ayuntadas. } \\
\text { E sy la lechuga } \\
\text { se enduresçe } \\
\text { ante que non } \\
\text { deue, sy qujer } \\
\text { por via que sea } \\
\text { enla tierra, sy } \\
\text { quier por el } \\
\text { tiempo, sy qujer } \\
\text { por la simjente, } \\
\text { tu arrancaras } \\
\text { la planta dela } \\
\text { lechuga, E } \\
\text { tornaras la a } \\
\text { plantar } \\
\text { otra vegada. \& } \\
\text { rregar la has } \\
\text { muchas vezes. \& } \\
\text { tornara tierna. E } \\
\text { avn deues saber } \\
\text { quela lechuga } \\
\text { rretiene la sabor } \\
\text { de diuersas } \\
\text { yeruas todo en } \\
\text { semble, por tal } \\
\text { manera deue }\end{array}$ & $\begin{array}{l}\text { Ibn Wafid } \\
\text { (attributed) }\end{array}$ & $\begin{array}{l}\text { Albertus } \\
\text { Magnus De } \\
\text { vegetabilibus }\end{array}$ & $\begin{array}{l}\text { Pliny Historia } \\
\text { naturalis } \\
\text { XIX:39 }\end{array}$ & $\begin{array}{l}\text { Pietro de } \\
\text { Crescenzi } \\
\text { sanguinem } \\
\text { generat \& } \\
\text { lac, \& urinam } \\
\text { prouocat \& } \\
\text { choleram } \\
\text { extinguit, } \\
\text { sanguinis } \\
\text { ebulitionem } \\
\text { refrigerat, } \\
\text { \& somnum } \\
\text { inducit. } \\
\text { Item ualet } \\
\text { contra calida } \\
\text { apostemata, ... } \\
\text { [other medicinal } \\
\text { uses follow] } \\
\text { (Crescenzi } \\
\text { I538:33I-332) }\end{array}$ & $\begin{array}{l} \\
\text { La primera } \\
\text { especie de } \\
\text { lechugas de } \\
\text { que se hace } \\
\text { mencion son } \\
\text { las comestibles, } \\
\text { comunes en } \\
\text { todas regiones, } \\
\text { las quales son } \\
\text { de tres especies; } \\
\text { unas de grande } \\
\text { y grueso pie, } \\
\text { de larga ancha } \\
\text { y gruesa hoja, } \\
\text { y cuyo tallo se } \\
\text { levanta de la } \\
\text { tierra como } \\
\text { un codo poco } \\
\text { mas o menos } \\
\text { [...] Quando } \\
\text { las lechugas } \\
\text { comienzan a } \\
\text { tener leche } \\
\text { (que es en } \\
\text { la primavera } \\
\text { quando ha } \\
\text { templado } \\
\text { el tiempo) } \\
\text { son menos } \\
\text { provechosas, } \\
\text { pues debilitan el } \\
\text { cuerpo del que } \\
\text { las come. [...] } \\
\text { Por lo demas, } \\
\text { Abu Abdalah } \\
\text { Ebn el Fasél y } \\
\text { otros son de } \\
\text { opinion, que } \\
\text { conviene a las } \\
\text { lechugas la } \\
\text { tierra gruesa } \\
\text { y el agua } \\
\text { dulce, y que } \\
\text { fuera de ellas } \\
\text { ninguna otra le } \\
\text { conviene: que } \\
\text { si se siembran } \\
\text { en tierra áspera } \\
\text { y fuerte se } \\
\text { ponen en ella } \\
\text { parduzcas; y } \\
\text { por quantos se } \\
\text { resquebraja con } \\
\text { la falta del agua, } \\
\text { no prevalecen } \\
\text { en ella a no ser } \\
\text { por medio de } \\
\text { riegos copiosos: }\end{array}$ \\
\hline
\end{tabular}




\begin{tabular}{|c|c|c|c|c|c|c|}
\hline Memòria & $\begin{array}{l}\text { Palladius } \\
\\
\text { hombre que } \\
\text { tu auras del } \\
\text { estiercol delas } \\
\text { cabras, E } \\
\text { suptilmente } \\
\text { con vna lezna, } \\
\text { o aguja tu las } \\
\text { foradaras \& } \\
\text { sacaras lo que } \\
\text { es en medio, E } \\
\text { despues meteras } \\
\text { dentro cada } \\
\text { vna delas pellas } \\
\text { dela cabra de } \\
\text { todas aquestas } \\
\text { simjentes, es a } \\
\text { saber simjente } \\
\text { de lechuga, } \\
\text { [fol. 5ov] de } \\
\text { mestuerço, de } \\
\text { Comjnos, de } \\
\text { Oruga, \& de } \\
\text { Alfalfega, E } \\
\text { despues meteras } \\
\text { las pellas dela } \\
\text { cabra de dentro } \\
\text { de estiercol en } \\
\text { tierra que sea } \\
\text { bien labrada. } \\
\text { \& nonlas metas } \\
\text { fondo \& cubre } \\
\text { las, E algunas } \\
\text { vezes fazen vn } \\
\text { poco a rregar, } \\
\text { o rruxar E } \\
\text { como comeras } \\
\text { de la lechuga, } \\
\text { quando la avras } \\
\text { trasplantada } \\
\text { segunt que de } \\
\text { suso es dicho, } \\
\text { rretendra } \\
\text { la sabor de } \\
\text { todas las otras } \\
\text { simjentes. } \\
\text { (Capuano } \\
\text { I99o:54) }\end{array}$ & $\begin{array}{l}\text { Ibn Wafid } \\
\text { (attributed) }\end{array}$ & $\begin{array}{l}\text { Albertus } \\
\text { Magnus De } \\
\text { vegetabilibus }\end{array}$ & $\begin{array}{l}\text { Pliny Historia } \\
\text { naturalis } \\
\text { XIX:39 }\end{array}$ & $\begin{array}{l}\text { Pietrode } \\
\text { Crescenzi }\end{array}$ & $\begin{array}{l} \\
\text { que para } \\
\text { trasplantaciones } \\
\text { se siembran en } \\
\text { tres tiempos, } \\
\text { tempranas, } \\
\text { medias y tardias: } \\
\text { que las primeras } \\
\text { se siembran } \\
\text { por septiembre } \\
\text { en tablares } \\
\text { labrados y } \\
\text { estercolados, } \\
\text { en sitios que } \\
\text { miren a perfecto } \\
\text { oriente de un } \\
\text { sol dominante, } \\
\text { revolviendo } \\
\text { blandamente su } \\
\text { simiente con la } \\
\text { tierra para que } \\
\text { quede con ella } \\
\text { incorporada, } \\
\text { introduciéndo- } \\
\text { les el agua en la } \\
\text { misma forma, } \\
\text { acudiéndoles } \\
\text { con ella una o } \\
\text { dos veces hasta } \\
\text { que nacen, y } \\
\text { regándolas } \\
\text { dos veces en } \\
\text { la semana } \\
\text { quando estan } \\
\text { medianamente } \\
\text { crecidas: que } \\
\text { hallándose en } \\
\text { competente } \\
\text { disposicion, se } \\
\text { trasplanten por } \\
\text { noviembre en } \\
\text { tablares hechos } \\
\text { en sitios donde } \\
\text { las bañe el sol } \\
\text { en el dia, no } \\
\text { dominados de } \\
\text { los vientos, y } \\
\text { que se hayan } \\
\text { labrado y } \\
\text { estercolado con } \\
\text { mucha copia } \\
\text { de estiércol } \\
\text { desmenuzado, y } \\
\text { de excremento } \\
\text { humano (el } \\
\text { qual es mejor } \\
\text { para ellas y } \\
\text { con el que } \\
\text { grandemente }\end{array}$ \\
\hline
\end{tabular}




\begin{tabular}{|l|l|l|l|l|l|l|}
\hline Memòria & Palladius & $\begin{array}{l}\text { Ibn Wafid } \\
\text { (attributed) }\end{array}$ & $\begin{array}{l}\text { Albertus } \\
\text { Magnus De } \\
\text { vegetabilibus }\end{array}$ & $\begin{array}{l}\text { Pliny Historia } \\
\text { naturalis } \\
\text { XIX:39 }\end{array}$ & $\begin{array}{l}\text { Pietro de } \\
\text { Crescenzi }\end{array}$ & $\begin{array}{l}\text { Ibn al-Awwam } \\
\end{array}$ \\
& & & & $\begin{array}{l}\text { prevalecen), } \\
\text { colocando en } \\
\text { ellos sus plantas } \\
\text { en filas a un } \\
\text { palmo o poco } \\
\text { mas de distancia } \\
\text { una de otra } \\
\text { a lo largo... } \\
\text { (Banqueri } \\
\text { I802:2, I45-148) }\end{array}$ \\
\hline
\end{tabular}

\section{${ }_{7}$ Index and glossary of terms related to horticulture}

The following list consists of terms related to horticulture found in the Memòria. The headwords are presented in the forms in which they appear in the text, followed by the modern singular masculine form in parentheses (when absent from the text) for nouns and adjectives, and in the case of verbs, the modern infinitive form (when absent). The English gloss that follows relates only to the specific horticultural context in which each word occurs, and in many cases represents a specialized meaning for the term. The number in parentheses at the end of each entry refers to the form's location in the text (chapter or footnote), but for a few high-frequency items in the list no location is given since they are found throughout the text.

abrich (abrigar) - Protect, shelter; protection (25)

aclarir - To thin $(\mathrm{I} 9,2 \mathrm{O})$

albergínies (albergínia) - Eggplant (Solanum melongena) (25)

albudeques (albudeca) - Citron melon (Citrullus lanatus var. citroides) (25)

alls (all) - Garlic (Allium sativum) $(\mathrm{I} 3,2 \mathrm{O})$

almolls (armolls) - Orache, Atriplex hortensis (6).

arbolam - Mesclun, i.e., mix of salad greens planted together in the same bed (6)

arenquats (arrancat $<$ arrancar) - Pulled up, harvested (20)

argullen (ergullar) - To develop or increase excessively, become leafy (I)

arranchar, arranquar, arrencar (arrancar) - To pull up, uproot (2, I3)

assahonar (assaonar) - To season, to mature, to ripen ( $(5$, I6)

astoig (estojar) - Store (I5)

avent - Advent $(8, \mathrm{II})$

axugar - To dry (n. II6)

axut - Dry (n. II6)

barbes (barba) - Roots of bulb-forming plants, especially of onions and leeks (n. Io8) 
bledes (bleda) - Swiss chard, Beta vulgaris var. cicla (6)

blet - Purple amaranth, Amaranthus blitum. See almolls (7)

bota - Barrel (n. II6)

bou - A blunt, thick wooden tool or member (n. Io8)

caboça - Bulb (I6)

cals viua (calç viva) - Lime (n. II6)

cama - Main stem of young plant (I)

cap - End, extremity (n. II6)

carabaça, carabaces, carabasses (carabassa) - Calabash (Lagenaria siceraria) (23)

ceba - Onion (I5). - porrera Long onion; variety of onion with an elongated bulb (I5); See note

93. - rodona Bulb-forming onion (I6)

cel - Sky (20)

cindries (síndria) - Watermelon (Citrullus lanatus) (25)

clar, clara, clares, clareta - I. Thinly, thinly spaced (I3, I5) 2. Clear; mild weather (I6)

clot - Hole (23)

cogombres (cogombre) - Cucumber (Cucumis sativa) (25)

col - Cabbage [in general]; - de sicilia Unidentified variety of cabbage (4); - de capdell Head cabbage (5)

colill - Cabbage sprout (6)

collar - To join or press together (I)

collir - To harvest (2I)

colpejar - To bruise (n. I5o)

copades (copat) - Having its leaves tightly closed around each other (5)

corquats (corcat) - Gnarled (20)

culles (cullir) - To pick, uproot; harvest (5)

cremar - To injure, damage (I5).

crestes (cresta) - High part of the furrow (I8)

cusen (cosir) - To sew (IO)

descusen (descosir) - Unsew, remove stitches (Io)

desexida - Final day, or days, end [of month] $(2,2 \mathrm{O})$

desfonsada (desfonat $<$ desfonar) - With the bottom removed (n. II6)

destrempar - To disolve (n. Iog)

dit - The width of a finger ( 15 )

draps (drap) - Cloth (23) 
dreçe (dreçar) - To straighten (I)

entracavar, entrecavar - To hoe around [crops] $\left(\mathrm{I}_{5}, \mathrm{I} 6\right)$

entrant - Beginning, opening days of (I5)

era- Garden bed (I)

erbolam - Mesclun, i.e., mix of salad greens planted together in the same bed $(6,7)$

escabesar - To take the tops off $(5)$

espeços, espesa, espessos, espeses (espès) - Thick, thickly (5, I9, 2O)

estiu - Summer (I5)

estores (estora) - Mat (23)

exada (aixada) - Hoe (5)

exempli - Proverb, saying $(2 \mathrm{O}, 23)$

exides (exit $<$ eixir) - Emerged, sprouted (5, 23, 24)

exir (eixir) - To emerge, sprout (23)

fangada (fangat $<$ fangar) - Dug up, cultivated (2O)

faves (fava) - Broadbeans, fava beans (Vicia faba) (27)

femar - To manure, to enrich with manure (n. Iog)

fem, fempta, fems - Manure

fesols (fesol) - Bean (Phaseolus vulgaris) (n. I52)

fica (ficar, aficar) - To stick in, insert (I4)

fira (ferir) - To strike (4)

forch - The distance between the thumb and index finger when both are fully extended (I5)

frasques (frasca) - Greens, tender branches, sprigs (6)

fulles (fulla) - Leaves (I9)

gelades (gelada) - Frost (I6, 23)

gita (gitar) - Throw (2)

graça (grassa) - Rich, fertile (24)

gra, grans - I. Seed (2O, 23) 2. Small piece (2I) 3. Clove (of garlic) (I4)

granetes (granet) - Somewhat big (5)

grill - Sprout; especially, the stalk and leaves of a member of the onion family when they first emerge from the bulb (I4, n. 9I)

grilen, grillada, grillen (grillar) - To sprout (IO, I3, n. IO8)

groç-Thickness (5)

groç, groça, groços, grossa, grosses - Large (5, I5, I6, I9, n. 89)

guaret, guoret - Cultivation, working of the soil; terrain that has been hoed or tilled (I, I5, I6) 
guaretada (guaretar) - To cultivate, hoe (I9)

hombra (ombra) - Shade (2O)

homplit (omplir) - Filled (I5)

hagost (agost) - August (II)

hix (eixir) - To emerge, to sprout (I6)

hort-Area in cultivation (n. IIO)

ivern (hivern) - Winter ( $\left.\mathrm{I}, 8, \mathrm{I}_{5}\right)$

ixen (eixir) - To emerge, to sprout (IO)

jelades (gelada) - Frost (II)

jorn - Day $(24,25)$

juhivert (julivert) - Parsley, Petroselinum sativum (26)

lavor (llavor) - Seed (IO, I6)

laurons (llauró) - Labor (title)

leig (lleig) - Unpleasant (I6)

leix, lexen (lleixar) - Let, allow (I5)

levada, llevada - Raised garden bed (I5, n. 98)

leyt (llet) - Milk (24)

llavor - Seed $(\mathrm{I} 5,20)$

llevant, llevau (llevar) - To remove (I9)

luna (lluna) - Moon; - nova - waxing moon; - vella waning moon

mà - Handbreadth ( 15$)$

mare - Mother (24) mare de les semençes 'principal sowing time’

mata - Stalks and leaves of a plant (I5)

melon - Melon (Cucumis melo) (25)

mesos (mès $<$ metre) - Placed, put (23)

moguda (mogut $<$ moure) - Moved, turned, cultivated (2O)

mogue (moure) - To move, move in on (23)

mostes (mosta) - Amount contained in both hands cupped together (2)

mota - I. Clump or ball of earth to which cling the roots of a plant to be transplanted ("Pilot de

terra agafada a les arrels d'un vegetal que es transplanta” $D C V B$ ) (I4). 2. Clump of plants

growing in close proximity to each other (I4) 3. Mound of soil (I4, 23)

nabina - Turnip seed (2O)

Nadal - Christmastime (8, II)

nap - Turnip (Brassica rapa) $(5,20)$ 
neula - Haze, fog (I3)

nou (noura, noure) - Injure, damage ( $(\mathrm{3}, \mathrm{I} 6)$

novelles (novell) - Young, new, immature (23)

omple (omplir) - Fill (23)

orle (orla) - Border (23)

ort (hort) - Area in cultivation (Title)

ortaliça (hortalissa) - Vegetable (Title, 2O)

ortolan (hortolà) - Gardener (Title, IO)

palm (pam) - Handspan (23)

Pascha, Paschor, Pascuor (Pasqua) - Easter (I, 2, 6)

pastanagues (pastenaga) - Carrot (Daucus carota) (9)

pensar - To care for, tend (Title)

plana (pla) - Level, flat (I5)

planter - Set, transplant, i.e., seedling or plant to be transplanted (I, 4, 23)

ple- Full moon (I, I9, 2I)

podrit - Rotted (I5)

pou - Well (IO)

pregon - Deep, deeply (I, I9, 23)

preses, presos (pres < prendre) - Established (I, I5, 23)

prima - [See terra] $(20)$

primarenchs, primarenques (primerenc)- Early-season, that is harvestable early (II, I3, I5, I6, $20,24,27)$

Quaresma - Lent (I, 9, 8)

quart - Quarter of moon's phase (I9)

rael, rahel - Root $(2,19)$

ràven (rave) - Radish (Raphanus sativus) (I8)

rech (regar, reguar) - To water, to irrigate.

regada - Watered $(20)$

regar, reguar, rreguar - To water.

reguiu - Irrigation (I3)

remullals (remulla'ls) remullades (remullar) - To soak $(23,25)$

romania (romanir, romandre) - To remain, to be left over (I)

ruxa (arruixar) - Sprinkle (5)

salvar - To store (I6) 
samal (semal)- Recipient for transporting manure on horseback (n. Io9)

scalunyes (ascalunya) - Member of the onion family, perhaps chives (Allium schoenoprasum)

(I4); See note 9I

seba, sebes (ceba) - Onions (I5, 2O)

semençes - Sowings (24)

sement - Seed (5)

senalla - Basket (IO)

sesta - Nones, early afternoon (23)

solch (solc) - Row, furrow (I5)

solegat (solegar) - Dried in the sun (24)

som - Shallow (I6)

sopar - To have supper (I6)

sostre- Layer (n. II6)

spay - Interval, space (25)

spès, spesses, spessos - Thick, thickly (I5).

spiguar, spiguen (spigar) - To bolt; to send up flowering stem (I, 2, I5, 26)

stoig (estojar) - Store (I6)

stores (estora) - Mat (23)

tallar - Cut away (n. II2)

tardana, tardanes, tardans (tardà) - Late-maturing (20, 24)

tardor - Autumn (I9)

tèbea (teb) - Lukewarm (23)

tendra (tendre) - Raw ( 17 )

tenir - To preserve (I5)

terra prima - Loose, granular soil (2O)

toquar (tocar) - To touch (23)

tova (tou) - Loose, well-worked (I8)

través - Width (23)

triar - To reserve, to set apart (I8)

troç (tros) - Piece, plot (5)

ull - Top of the main stem or shoot (apical meristem) of a plant (I, 23)

vaques (vaca) - Cows (24)

vendre - To sell (I8)

venemes, veremes (verema) - Vintage time (3) 
vexell (vaixell) - Container (5)

vores (vora) - Borders (n. 45)

xerevies, xerovies, xarovies (xirivia) - Parsnip (Pastinaca sativa) (2I)

xufes (xufla) - Yellow nutsedge, tiger nuts (Cyperus esculentus) (22) 